\title{
BIOLOGICAL AND PSYCHOSOCIAL FACTORS ASSOCIATED WITH REJECTION SENSITIVITY IN RELATION TO DEPRESSIVE SYMPTOMS
}

\author{
Robbie Woods
}

A thesis submitted to the Faculty of Graduate Studies and Postdoctoral Affairs in partial fulfillment of the requirements for

\author{
Master's of Science \\ in \\ Neuroscience
Carleton University
Ottawa, Canada

(C)2016 Robbie Woods 


\begin{abstract}
Rejection sensitivity is a cognitive-affective processing disposition, whereby individuals anxiously expect, readily perceive, and overreact to rejection. These characteristics are believed to emerge in response to rejection and interpersonal trauma experienced in childhood and adolescence. Maladaptive cognitions and affective responses to rejection might subsequently contribute to greater depressive symptoms, including suicide ideation. A single nucleotide polymorphism (SNP) on the OXTR gene (rs53576) has emerged as an important player in respects to social behaviours. It may thus provide a biological basis for rejection sensitivity given that individuals with a mutation on the OXTR gene often display social deficits. As such, the additive or synergistic effect of interpersonal trauma and genetic predisposition might culminate in greater rejection sensitivity. Although these factors are understood to contribute to rejection sensitivity, it is important to consider how recent social interactions (e.g. social support and unsupport) might attenuate or exacerbate adverse mental health outcomes. In the current study ( $N$ $=384$ ), it was determined that in the presence of the OXTR gene mutation on both alleles (AA), individuals who had experienced interpersonal trauma displayed greater rejection sensitivity than in the absence of the mutation (GG/AG). It was also determined that perceived social support buffered the relationship between rejection sensitivity and depressive symptoms, such that the relationship between rejection sensitivity and depressive symptoms was blunted among individuals with higher perceived support. Conversely, unsupportive social interaction exacerbated depressive symptoms in relation to rejection sensitivity. That is, the relationship between rejection sensitivity and depressive symptoms was stronger among individuals reporting high unsupport. Taken together, this study sheds light on the cognitive-affective responses
\end{abstract}


related to rejection sensitivity, and understanding some of the dynamic biological and psychosocial processes that contribute to mental health outcomes. 


\section{Acknowledgements}

This journey would not have been complete without the help of many people. I have said it countless times how fortunate I have been to work with such a supportive and dedicated supervisor, Dr. Hymie Anisman. As a supervisor and mentor, he has given me so many opportunities to grow, both as an academic and as a person. I will cherish all the times sitting in his office, receiving words of encouragement, listening to old stories, or just discussing life. Dr. Kim Matheson has also been exceptionally supportive in helping me grow professionally, and providing opportunities to escape the city for much needed breaks. I would not be where I am today without the help of both Dr. Robyn McQuaid and Dr. Opal McInnis. As mentors, they helped navigate the confusing world of graduate school; as friends, made the journey entertaining (to say the least). I am personally indebted to Marc Bedard, who has been a great source of support over the past two years, as well as my fellow lab mates. Lastly, I must thank my family for helping me through this journey, I am eternally grateful. 


\section{Table of Contents}

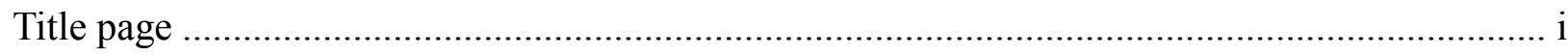

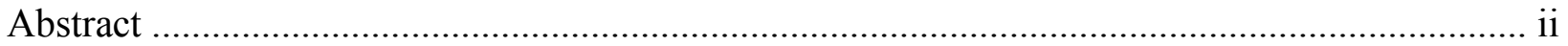

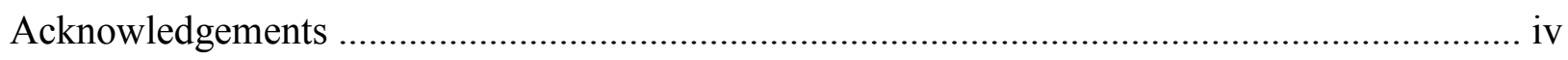

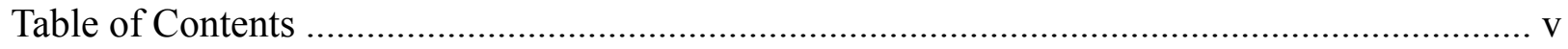

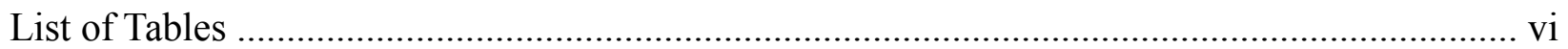

List of Figures ........................................................................................................... vii

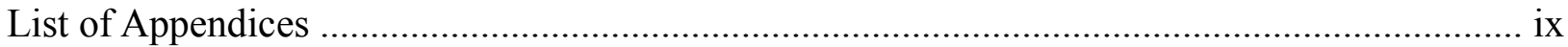

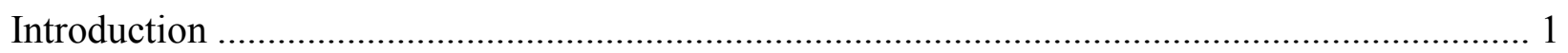

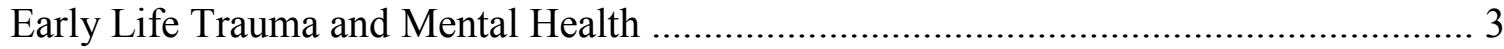

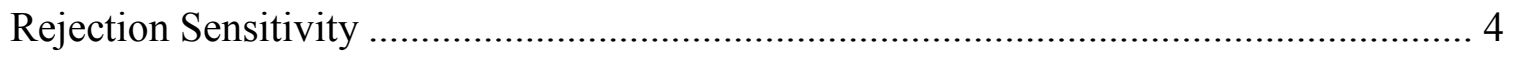

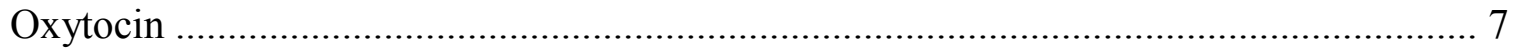

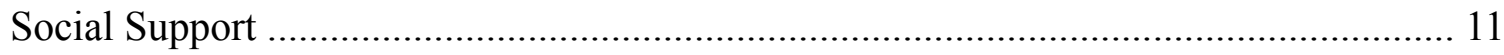

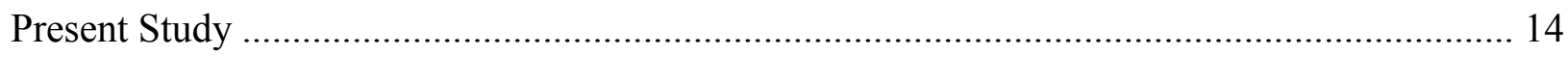

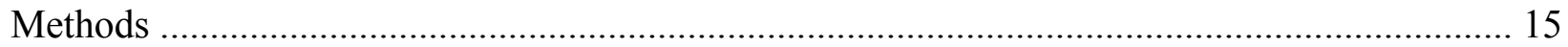

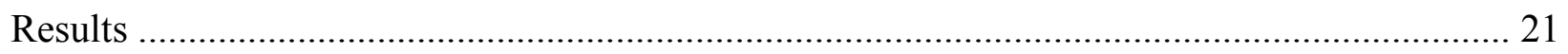

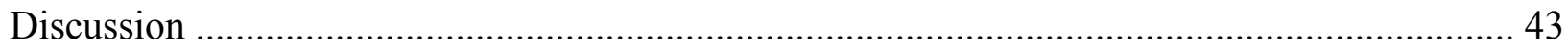

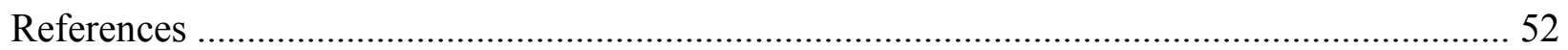

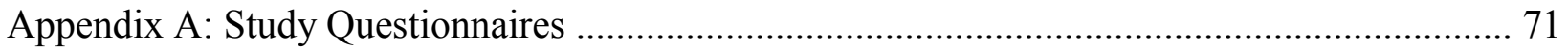




\section{List of Tables}

Table 1. Relations between depressive symptoms, perceived social support, unsupportive social interactions, rejection sensitivity, and early-life trauma ....................................... 23

Table 2. Mean, Standard Error, $t$-test $p$-values of study variables by gender ......................... 24

Table 3. Mean, Standard Error, ANOVA $p$-values of study variables by OXTR rs53576

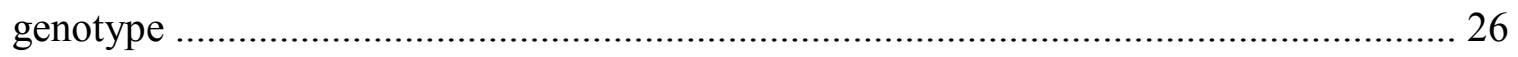




\section{List of Figures}

Figure 1a. Schematic overview of the moderated mediation analysis between interpersonal trauma and depressive scores through rejection sensitivity was moderated by the OXTR rs53576 genotype 30

Figure 1b. The relationship between interpersonal trauma and rejection sensitivity as a function of OXTR rs53576 genotype (GG/AG vs. AA)

Figure 1c. Schematic overview of the moderated mediation analysis of which interpersonal trauma and suicide ideation was mediated through rejection sensitivity, and moderated by the OXTR rs53576 genotype 32

Figure 2a. Schematic representation of the moderated mediation analysis of rejection sensitivity mediating the relationship between interpersonal trauma and depressive scores, and moderated by perceived social support

Figure $2 \mathrm{~b}$. The moderating role of perceived social support in relation between rejection sensitivity and depressive symptoms 35

Figure 2c. Schematic depiction of the moderated mediation analysis. Interpersonal trauma and suicide ideation was mediated through rejection sensitivity, and moderated by perceived social support

Figure $2 \mathrm{~d}$. The interaction between rejection sensitivity and social support on suicide ideation

Figure 3a. Schematic representation of the moderated mediation relationship in which interpersonal trauma and depressive scores was mediated through rejection sensitivity, and moderated by peer unsupport 
Figure $3 \mathrm{~b}$. The moderating role of peer unsupport in relation between rejection sensitivity and

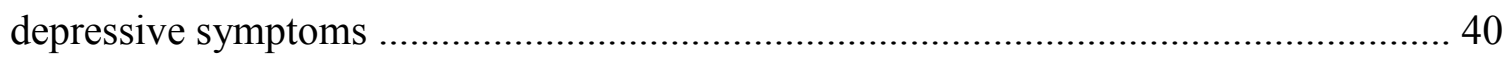

Figure 3c. Schematic depiction of the moderated mediation analysis. Interpersonal trauma and suicide ideation was mediated through rejection sensitivity, and moderated by peer

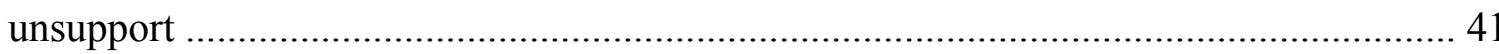

Figure 3d. The moderating role of peer unsupport in relation between rejection sensitivity and

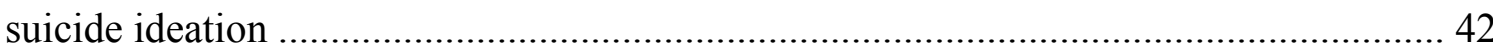




\section{List of Appendices}

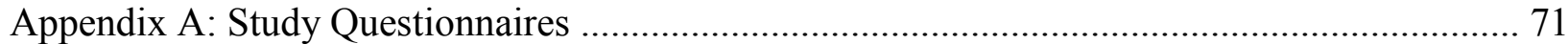




\section{Introduction}

Approximately $70-90 \%$ of people report experiencing at least one type of intense negative event at some point in their life (Anders, Fraziers \& Shallcross, 2012; Kilpatrick et al., 2013, Norris, 1992). Although most individuals manage to cope well with these adversities, such events are strongly related to the development of mental health issues, such as depression, anxiety, and posttraumatic stress disorder (PTSD; Arnow, 2004; Gilbert et al., 2009; Nanni et al, 2012). Moreover, the chronicity of these disorders may be directly related to the number of traumatic events experienced (Bernet \& Stein, 1999).

It is believed that traumatic events that are interpersonal in nature might contribute to deficits in psychosocial functioning and the development of adverse mental health outcomes. Indeed, interpersonal traumas (e.g. emotional, physical, sexual abuse, and neglect) in the form of perceived rejection may contribute to elevated sensitivity to later social rejection (Goodman, Fertuck, Chesin, Lichenstein \& Stanley, 2014). Moreover, individuals with a disposition that is sensitive to rejection are more likely to perceive ambiguous social interactions as actually rejection (Downey \& Feldman, 1996; Zimmer-Gembeck \& Nesdale, 2013). This comes at a cost, as rejection sensitivity may be accompanied by a number of negative interpersonal characteristics, including aggression (Sijtsema, Shoulberg \& Murray-Close, 2011), social avoidance (MacDonald \& Leary, 2005; Watson \& Nesdale, 2012), and over-compensatory behaviours (Downey \& Ayduk, 2000).

Oxytocin has been implicated in the development of mood disorders, as altered serum levels of this hormone have been associated with depressive features (Cyranowski, Hofkens, Frank, Seltman, Cai \& Amico, 2008), whereas intranasal oxytocin administration attenuates psychological distress among some individuals (IsHak, Kahloon \& Fakhry, 2011). Moreover, a 
genetic variant within the oxytocin receptor (OXTR) gene has been implicated in prosocial behaviours, such as trait empathy (Rodrigues, Saslow, Garcia, John \& Keltner, 2009) and social support (Krueger et al., 2012). In contrast, carriers of a particular oxytocin receptor polymorphism (rs53576) were more likely to display depression than individuals without this mutation (Thompson, Hammen, Starr \& Najman, 2014). As such, although individuals without the mutation (GG) seem to be more negatively impacted by ostracism (McQuaid, McInnis, Matheson \& Anisman, 2015), both low rejection sensitivity GG carriers and high rejection sensitivity A carriers displayed greater cortisol release following a psychosocial stressor (Auer, Byrd-Craven, Grant \& Granger, 2015). Furthermore, individuals who characteristically display interpersonal instability (e.g. Borderline Personality Disorder) are commonly A carriers (Hammen, Bower \& Cole, 2015). In this regard, it appears that having at least one mutation on the OXTR SNP (rs53576) might be dispositionally sensitive to negative social behaviours (e.g. rejection).

Despite the knowledge that depression is marked by social disturbances, and that psychosocial factors may be pivotal in the provocation and maintenance of this disorder, treatment efforts have largely focused on the biological and cognitive aspects of depression. Attaining social support may be important in diminishing the impact of stressors that lead to depression (Jorden, Matheson \& Anisman, 2009; Thorsteinsson, Ryan \& Sveinbjornsdottir, 2013). However, individuals who readily perceive and are sensitive to rejection often lack a strong social network (Downey, Freitas, Michaelis \& Khouri, 1998). A vicious cycle can emerge when perceived rejection to ambiguous social situations results in interpersonal conflict or social withdrawal (Downey, Mougios, Ayduk, London \& Shoda, 2004).

In the present study, it was of interest to examine the relationship between early 
interpersonal trauma and depressive symptoms (including suicide ideation), and to determine the mediating role of rejection sensitivity. Furthermore, this study examined whether individuals with the OXTR (rs53576) gene mutation would report great rejection sensitivity. Although it is understood that G carriers of the OXTR (rs53576) gene are more sensitive to salient social cues, interactions between interpersonal trauma and this gene may predict a disposition that is sensitive to rejection. Furthermore, supportive and unsupportive social interactions each might interact with rejection sensitivity to predict mental health outcomes.

\section{Early Life Trauma and Mental Health}

The Public Health Agency of Canada (2010) reported over 85,000 substantiated child maltreatment cases in 2008 , most of which comprised interpersonal violence, neglect, and physical abuse. Indeed, the Developmental Victimization Survey (DVS), which assessed children between the ages of 2 and 17 years old, revealed that $71 \%$ of the sample reported being victims of at least one instance of abuse within the past year, including childhood maltreatment, peer and sibling victimization, sexual victimization, observing victimization, and conventional crime victimization (Finkelhor, Ormrod \& Turner, 2009). Importantly, isolated instances of abuse are uncommon, particularly in the case of childhood maltreatment, which typically comprises repeated victimization (Duncan, 1999).

Time does not necessarily heal all wounds, as a history of interpersonal trauma (emotional, physical, sexual abuse, and neglect) remain deleterious to later development of psychiatric disorders. Several mental health concerns in adulthood (e.g. eating disorders, suicide attempts, drug use, and risky sexual behaviours) can be attributed, in part, to traumatic events that occurred during childhood and adolescence (Hovens et al., 2010; Norman, Byambaa, De, 
Butchart, Scott \& Vos, 2012). There is a strong dose-dependent response between the number of interpersonal traumas and the risk for depression (De Marco, 2000; Edwards, Holden, Felitti \& Anda, 2003). In general, individuals with a history of early interpersonal trauma are twice as likely to develop depression (Widom, DuMont \& Czaja, 2007), and display recurrent or persistent depressive symptoms, compared to those without such a history (Bernet \& Stein, 1999; Norman et al., 2012). Furthermore, early interpersonal trauma is predictive of suicidal behaviours (Ehnvall, Parker, Hadzi-Pavlovic \& Mahli, 2008; Fergusson, McLeod \& Horwood, 2013) in that individuals with a history of child abuse are 4.3 times more likely to report suicide ideation, 4.7 times more likely to have a suicide plan, and 6.1 times more likely to attempt suicide, compared to individuals without a history of child abuse (Afifi et al., 2016).

\section{Rejection Sensitivity}

A fundamental motivation in life is to be socially accepted and belong (Leary \& Baumeister, 2000). Conversely, social rejection (e.g. bullying, discrimination) can be a great source of distress and deleterious to wellbeing (Bond, Carlin, Thomas, Rubin \& Patton, 2001; Brendgen \& Vitaro, 2008; Venable, Carey, Blair \& Littlewood, 2006; Williams, Neighbors \& Jackson, 2003). Indeed, rejection and ostracism from close friends and family members has been associated with devalued self-worth (Stillman, Baumeister, Lambert, Crescioni, DeWall \& Fincham, 2009), and greater feelings of loneliness (Leary, 2015), and depression (Witvliet, Brendgen, Van Lier, Koot \& Vitaro, 2010). Furthermore, social rejection can contribute to alterations in neuroendocrine (Blackhart, Eckel \& Tice, 2007; Stroud et al., 2009) and autonomic (Hawkley, Thisted, Masi \& Cacioppo, 2010; IJzerman, Gallucci, Pouw, Weißgerber, Van Doesum \& Williams, 2012) processes. 
Although rejection in itself is difficult (see Zadro, Williams \& Richardson, 2004), individuals with a disposition primed to perceive rejection typically internalize it (Downey \& Feldman, 1996). Rejection sensitivity is a cognitive-affective processing disposition, whereby individuals anxiously expect, readily perceive, and overreact to rejection (Downey \& Feldman, 1996). It is believed to arise from times when a child's needs are consistently met with rejection (Downey et al., 1998), thereby developing a "once bitten, twice shy" expectation towards rejection (Olsson, Carmona, Downey, Bolger \& Ochsner, 2013). Although this might serve a defensive purpose by becoming hyper-vigilant to cues of rejection (Downey, Khouri \& Feldman, 1997), the prospect of rejection can lead such individuals to impede the formation of meaningful relationships (Downey, Khouri \& Feldman, 1997), and undermine the relationships they have already developed, further contributing to rejection (Downey, Freitas, Michaelis \& Khouri, 1998). Furthermore, rejection-sensitive individuals can become defensive, even hostile, towards others, in response to the slightest cues rejection, resulting in a self-perpetual cycle (or selffulfilling prophecy) of interpersonal conflict (Downey et al., 2004; Downey et al., 1998). Indeed, rejection-sensitive individuals display greater aggression towards others when rejected (Ayduk, Gyurak \& Leurssen, 2008), perpetrate dating partner violence (Downey et al., 2000), and domestic violence (Romero-Canyas, Downey, Berenson, Ayduk \& Kang, 2010). In addition to relational conflict, rejection sensitivity is associated with lack of deservingness (Ayduk, Gyurak \& Leurssen, 2008), sacrificing personal well-being to gain acceptance (e.g. engaging in risky behaviour, suppressing authentic feelings; Ayduk, Mendoza-Denton, Mischel, Downey, Peake \& Rodriguez, 2000), self-silencing (Harper, Dickson \& Welsh, 2006), and self-harm (Ayduk et al., 2008). Given that rejection sensitivity contributes to disturbed interpersonal cognitions and behaviours, it might be a risk factor for the development of depression. Indeed, woman scoring 
high on rejection sensitivity are twice more likely to develop depressive symptoms following a partner-initiated breakup compared to women scoring low rejection sensitivity (Ayduk, Downey \& Kim, 2001). Furthermore, even during times of remission, individuals with atypical features of depression display persistent rejection sensitivity (Ravindran et al., 2002).

\section{Cortical association of rejection sensitivity}

Social rejection activates the same cortical regions associated with physical pain (e.g. dorsal anterior cingulate cortex, anterior insula; Kross, Berman, Mischel, Smith \& Wager 2011), suggesting, in a sense, that social rejection can hurt as much as physical pain. This might explain why emotional abuse and neglect might have a lasting effect on mental health (Eisenberg, 2012). Indeed, individual living with somatoform disorder, who expressed pain without biological cause, reported greater history of childhood emotional abuse (Brown, Schrag \& Trimble, 2005), and women high in rejection sensitivity reported greater pain catastrophizing in an ischemic pain task (Wilson \& Ruben, 2011). Moreover, rejection experienced in a laboratory setting was associated with greater activity in the anterior insula, dorsal anterior cingulate cortex, and anterior cingulate cortex (Sanfey et al., 2003), and bilateral activation of the amygdala (Gospic et al., 2011). In a measure of dispositional sensitivity to rejection, rejection-sensitive individuals displayed blunted activation on the lateral prefrontal cortex and superior frontal gyrus (important in regulating response to stimuli; Kross, Egner, Ochsner, Hirsch \& Downey, 2007), and greater activity in the dorsal anterior cingulate cortex to disapproving faces (Burkland, Eisenberger \& Lieberman, 2007). 


\section{Oxytocin}

Oxytocin is a peptide hormone produced by parvocellular and magnocellular secretory neurons in the periventricular and supraoptic nuclei of the hypothalamus, which project to the posterior pituitary gland (Meyer-Lindenberg, Domes, Kirsch \& Heinrichs, 2011). In response to social behaviours (e.g. sucking pups), synchronized bursts of oxytocin are released into the blood stream (Gimpl \& Fahrenholz, 2001). As well, oxytocin is also present in limbic brain regions and the brain stem (Veening, de Jong \& Barendregt, 2010), and oxytocin receptors are expressed in the hypothalamus, anterior cingulate, prefrontal cortex, ventromedial prefrontal cortex, amygdala, and brainstem (Kumsta \& Heinrichs, 2012). Oxytocin has been implicated as an important player with respect to several social behaviours, including pair bonding, maternal care and aggression, and sexual behaviour (Neumann, 2008). Moreover, oxytocin has been associated with a number of behaviours that may facilitate the strengthening of social bonds, or favor individuals becoming more perceptive to social nuances, such as emotional expressions (e.g. happy, fearful, angry; Domes et al., 2010; Guastella, Mitchell \& Matthews, 2008; Lischke, Berger, Prehn, Heinrichs, Herpertz \& Domes, 2012; Marsh, Yu, Pine \& Blair, 2010). Indeed, oxytocin might dampen the negative response to rejection (willingness to play Cyberball again; Alvares, Hickie \& Guastella, 2010). However, this might not be the case among socially anxious individuals, who are characteristically fearful of rejection (Voncken, Alden, Bögels \& Roelofs, 2008). Indeed, socially anxious individuals undergoing oxytocin treatment had faster recognition of negative facial expressions (e.g. fear and disgust; Fang, Hoge, Heinrichs \& Hofmann, 2014), suggesting oxytocin might increase the salience to social cues among individuals who expect rejection.

In response to a stressor, oxytocin has been found to modulate hypothalamic-pituitary- 
adrenal (HPA) axis activity, essentially diminishing the stress response. Indeed, both rodent and human models have demonstrated elevation in oxytocin in response to a stressor. Intracerebral oxytocin administration in rodents inhibits HPA activation (Neumann, Krömer, Toschi \& Ebner, 2000) and, conversely, infusion of an oxytocin receptor antagonist into the periventricular nucleus of the hypothalamus before having mice go through a physical stressor resulted in elevated adrenocorticotropin hormone (ACTH; Neumann, Wigger, Torner, Holsboer \& Landgraf, 2000). Moreover, women undergoing an uncontrollable stressor experienced elevations in plasma oxytocin (Sanders, Freilicher \& Lightman, 1990), suggesting that oxytocin is a modulator of stress responses in a manner that makes individuals more perceptive to social support. Indeed, the warm touch of a supportive partner resulted in elevated plasma oxytocin among women undergoing a laboratory stressor (Grewen, Girdler, Amico \& Light, 2005).

It has become of interest to examine the impact of exogenous oxytocin in relation to stressors using intranasal sprays. Individuals undergoing a psychosocial stressor who received oxytocin treatment (and social support) displayed reduced salivary cortisol levels (Heinrichs, Baumgartner, Kirschbaum \& Ehlert, 2003), and increased parasympathetic cardiac control (Norman, Cacioppo, Morris, Malarkey, Berntson \& DeVries, 2011). Tellingly, when oxytocin was administered intranasally in couples asked to discuss a recent interpersonal conflict, in addition to a reduction in cortisol release, there was a reduction in negative behaviours (Ditzen, Schaer, Gabriel, Bodenmann, Ehlert \& Heinrichs, 2009), suggesting oxytocin might blunt the effects of negative social interactions (e.g. rejection). Indeed, intranasal oxytocin blunted cortisol responses among women undergoing a social rejection paradigm (Linnen, Ellenbogen, Cardoso \& Joober, 2012). Interestingly, Flanagan et al. (2015) found that intranasal oxytocin moderated the relationship between childhood maltreatment and stress reactivity. Individuals who received 
intranasal oxytocin exhibited a blunted stress response to a psychosocial stressor, whereas individuals in the placebo group who reported greater childhood maltreatment showed higher reactivity to stress (Flanagan, Baker, McRae-Clark, Brady \& Moran Santa Maria, 2015).

In essence, it seems that oxytocin might enhance the positive feelings obtained from social interactions, and may diminish the impact of negative stimuli depending upon the social context. This could have occurred through effects on dopamine functioning within the nucleus accumbens (Dölen, Darvishzadeh, Huang \& Malenka, 2013) or through the mobilization of the cannabis-like neurotransmitter, anandamide, within this brain area (Wei et al., 2015). It may be of particular significance that diminished oxytocin has been implicated in the development of depression (Cyranowski et al., 2008). Individuals seeking antidepressant or electroconvulsive therapy treatments for major depressive disorder had decreased serum oxytocin levels compared to healthy controls (Ozsoy, Esel \& Kula, 2009), and chronically depressed individuals displayed a decrease in oxytocin levels following a social rejection paradigm (Jobst et al., 2015) potentially explaining the diminished social interactions evident among depressed individuals.

\section{OXTR gene rs 53576}

There has been recent interest in the contribution of oxytocin-related genetic factors in the adoption of prosocial behaviors. In this regard, several studies assessed the relationship between prosocial behaviors and the oxytocin receptor gene (OXTR), rs53576. A singlenucleotide polymorphism (SNP) located on the 3p25 chromosome (Gimpl \& Fahrenholz, 2001), involving a guanine $(\mathrm{G})$ to adenine (A) substitution, located on the third intron of the OXTR has received considerable attention in this regard. In line with the prosocial nature of oxytocin, relative to individuals carrying the mutation, those with the common $\mathrm{G}$ allele $(\mathrm{GG} / \mathrm{AG})$ displayed 
greater empathy (Rodrigues et al., 2009), trust (Krueger et al., 2012), and social sensitivity (McQuaid, McInnis, Matheson \& Anisman, 2015), and less loneliness (Lucht et al., 2009). Moreover, when undergoing a psychosocial stressor, G carriers displayed lower salivary cortisol when supported by a friend, than $\mathrm{G}$ carriers who did not received social support. In contrast, among individuals with the AA genotype cortisol did not differ between support and no-support conditions (Chen, Kumsta, von Dawans, Monakhov, Ebstein \& Heinrichs, 2011). As well, the AA genotype has been linked to maladaptive coping (McInnis et al., 2015), and depressive symptoms (Saphire-Bernstein, Way, Kim, Sherman \& Taylor, 2011; McQuaid et al., 2013). As such, the AA genotype appears to be linked to interpersonal deficits associated with a number of mental health issues, including borderline personality disorder (Bungert, Liebke, Thome, Haeussler, Bohus \& Lis, 2015).

Rather than suggesting individuals with the 'favorable' gene (GG) are better adjusted to handle social processes, there is increasing support that the OXTR gene might be advantageous under positive conditions, but deleterious under negative circumstances (i.e., differential susceptibility hypothesis; McQuaid et al., 2013; McQuaid et al., 2015; Smearman, Winiarski, Brennan, Najman \& Johnson, 2015). In this regard, the favorable genotype, for better or for worse, might display greater sensitivity to adversity (e.g. early life trauma; Belsky, BakermansKranenburg \& Van IJzendoorn, 2007; Belsky \& Pluess, 2009). However, inconsistencies in the literature remain regarding OXTR in relation social sensitivity. In this regard, it is possible that the genotype that accompanies less prosocial (AA), and favors sensitivity to rejection and thus might be dispose toward greater loss, than among the more socially adept $\mathrm{G}$ carriers. Indeed, early interpersonal trauma predicted greater borderline personality characteristics only among A carriers (Cicchetti, Rogosch, Hecht, Crick \& Hetzel, 2014; Hammen, Bower \& Cole, 2015). 


\section{Social Support}

Social support buffers against the impact of a stressor by influencing the appraisal of a stressful event, or by providing resources to facilitate coping (Aspinwall \& Taylor, 1997; Cohen \& Wills, 1985). Provisions of support may be expressed through emotional support (receiving love and affection), affirmation support (providing feeling of belonging), tangible support (providing financial and/or material goods), and informational support (providing advice, guidance, and suggestions; Langford, Bowsher, Maloney, Lillis, 1997). Indeed, social support has the capacity to influence various forms of coping, and serves multiple functions depending upon the stressor at hand. For instance, receiving financial (tangible) support can be an example of problem-focused coping as it may help diminish the stresses of paying off a loan, actively reducing the stressor (Matheson \& Anisman, 2003). Support can also be an effective method of emotion-focused coping through emotional comfort at times when a stressor is out of the person's control, or to distract from a negative stressor (avoidant-focused coping; Matheson \& Anisman, 2003). As well, receiving support from a friend buffered distress when ostracized (Cyberball), however, this primarily occurred among individuals with high self-esteem (Teng \& Chen, 2012). Given that rejection sensitivity is negatively associated with self-esteem (Sommer \& Baumeister, 2002), it is reasonable to expect that social support might not be effective among those sensitive to rejection and feelings of inadequacy. Furthermore, social deficits common among rejectionsensitive individuals typically display aggressive or anxious expectancies of rejection. Indeed, angry expectations of rejection increase outward aggression and feelings of victimization, thus possibly diminishing social resources, whereas anxious expectations predict greater social anxiety and social withdrawal. As such, with expectancy for rejection, underestimating the level of social support might be associated with greater feelings of loneliness and depressive 
symptoms (London, Downey, Bonica \& Paltin, 2007).

Although attaining social support may be important in diminishing the impact of stressors that lead to depression (Jorden, Matheson \& Anisman, 2009), deficits in psychosocial functioning are common among individuals living with depression, which may be attributed to the individual's loss of interest in once pleasurable activities (anhedonia; American Psychological Association, 2013), including social engagement. The relationship between depression and lack of social support is, however, a two way street; although individuals living with depression may withdraw from social interactions, reducing opportunities of receiving support (Väänänen, Marttunen, Helminen \& Kaltiala-Heino, 2014), low provisions of support can also contribute to the emergence and maintenance of depressive disorders (Grav, Hellzèn, Romild \& Stordal, 2012), and may be predictive of poorer treatment response (Mohr, Classen \& Barrera, 2004). Moreover, social withdrawal in childhood is considered a risk factor for later interpersonal deficits and predictive of the development of depression in young adulthood (Katz, Conway, Hammen, Brennan \& Najman, 2011). Since rejection sensitivity fosters interpersonal conflict and depressive symptoms (Ayduk, Downey \& Kim, 2001), high rejection sensitivity individuals might lack supportive resources. When the possibility of rejection is high, individuals will use social avoidance behaviours (particularly rejection-sensitive individuals) to evade rejection (MacDonald \& Leary, 2005; Watson \& Nesdale, 2012), thereby contributing to greater feelings of loneliness (London et al., 2007).

It ought to be underscored that recalling supportive behaviours (received social support) may be an approximate measure of social support (Sarason, Sarason \& Pierce, 1990), however, it has not been consistently associated with mental health outcomes (Melrose, Brown \& Wood, 2015). Rather, self-perceptions of general availability of support and satisfaction with it 
(perceived support; Sarason, Sarason \& Pierce, 1990) have been more strongly associated with overall mental health (Barrera, 2000; Clara, Cox, Enns, Murrey \& Torgudc, 2003). Furthermore, the association between perceived and received social support is relatively small, as a metaanalysis of 23 studies revealed a weak correlation between the two constructs (Haber, Cohen, Lucas \& Baltes, 2007). The distinction between received and perceived social support is also important given that depressed individuals typically display negative cognitive biases (Amann, 1991; Lakey \& Cassady 1990), which may undermine recollections of supportive behaviours, and distort perceptions (perceived) wherein individuals report having had little support available or encountered behaviours that were unsupportive.

\section{Unsupportive Social Interactions}

When social support is sought, but is not received as expected, or comes in a form that is perceived as being inadequate, these unsupportive social interactions may be predictive of depressive symptoms above and beyond simply a lack of available support (Ingram et al., 1999). These negative interactions include minimizing of problems, blaming the individual, distancing from the person and their problem, and bumbling attempts to provide support (Ingram, Betz, Mindes, Schmitt \& Smith, 2001; McInnis, McQuaid, Matheson \& Anisman, 2015). Although the link between unsupportive social interactions and rejection has not been established, such behaviours do follow the same vein. Among First Nations adults, unsupport and perceived discrimination (including verbal rejection) interacted to predict depressive scores (McQuaid et al., 2015). Furthermore, unsupportive social interactions were associated with borderline personality feature (Elzy, 2009), and victims of assault by someone familiar (can be perceived as rejection) were associated with greater perceptions of unsupportive interactions, and more severe 
depressive symptoms (Jorden, Matheson \& Anisman, 2009).

\section{Present Study}

Despite the knowledge that the carriers of the OXTR (rs53576) gene polymorphism (A) are less socially adept, it is not entirely understood how interpersonal trauma might contribute to social deficits and depressive symptoms. The purpose of the present study was to examine whether rejection sensitivity mediated the relationship between early interpersonal trauma and depressive symptoms (including suicide ideation), and whether these relations would be moderated by the presence/absence of a polymorphism on the gene that codes for OXTR. Furthermore, it was of interest to examine if recent positive and negative social interactions contributed to these relationships. Specifically, it was hypothesized that:

1. individuals exposed to greater early life trauma would display higher depressive symptoms (including suicide ideation); This relation would be mediated by rejection sensitivity.

2. the OXTR gene would moderate the relationship between trauma and rejection sensitivity, such that AA carriers exposed to interpersonal trauma will display higher rejection sensitivity.

3. social support would interact with rejection sensitivity to predict depressive scores (including suicide ideation). Specifically, the relationship between rejection sensitivity and depressive scores would be stronger among individuals with lower perceived social support. Moreover, the relationship between rejection sensitivity and suicide ideation would be stronger among individuals with lower perceived social support.

4. unsupportive social interactions would moderate the relationship between rejection 
sensitivity and depressive scores (including suicide ideation). Specifically, the relationship between rejection sensitivity and depressive scores would be stronger among individuals with higher unsupportive social interactions. Moreover, the relationship between rejection sensitivity and suicide ideation would be stronger among individuals reporting greater unsupportive social interactions. 


\section{Methods}

\section{Participants}

Participants included 384 White/Euro-Caucasian undergraduate students at Carleton University (266 female, 118 male) who were recruited through the university's onlinerecruitment system. Ages ranged from 17 to $52(M=19.50, S D=3.65)$. Due to population stratification necessary for genetic analyses, the current study examined a homogeneous Caucasian sample. Relationship status varied, with half the sample currently single $(50.4 \%)$, or casually dating $(12.3 \%)$, in a serious relationship (29.1\%), recently broken up (3.1\%), living with their partner $(3.4 \%)$, or married/engaged $(1.5 \%)$,

\section{Procedure}

Upon arrival to the laboratory, participants signed an informed consent, after which they completed demographic questions, including history of psychological disorders, as well as measures of current depressive symptoms, provisions of social support, peer unsupportive social interactions, rejection sensitivity, and traumatic life events (see Appendix A). Participants then provided a single saliva sample for later genotyping. Once completed, participants received written debriefing and compensated with course credit. Carleton University's Ethics Committee for Psychological Research approved this study.

\section{Genotyping}

Samples for genotyping were collected using Norgen collection kits (Norgen Biotek Corp., Thorold, Ontario Canada). Genomic DNA was extracted from the sample collection kits according to the manufacturer's instructions and diluted to approximately equal concentration 
(20 ng/ $\mu \mathrm{L}$ ). Samples were sent for genotyping to McGill University and Génome Québec Innovation Centre (Montreal, Canada). Using polymerase chain reaction (PCR), the DNA was amplified, and QIAXcel was used to determine amplification status. Shrimp alkaline phosphatase was used to remove all unincorporated deoxyribose nucleoside triphosphates (dNTPs). One probe per marker was used to do a single base extension and the product was desalted using $6 \mathrm{mg}$ of resin. The product was spotted on Agena BioScience 96-well chip using a Samsung Nanodispenser, and the chip read by a Mass Spectrometer. A manual analysis was done for each marker. Primer sequences were as follows:

\section{OXTR F1 forward: ACGTTGGATGTCCCCATCTGTAGAATGAGC OXTR reverse: ACGTTGGATGGCACAGCATTCATGGAAAGG OXTR probe: CTCTGTGGGACTGAGGA}

The distribution of OXTR polymorphism comprised 186 individuals with homozygote GG genotype (132 female, 54 male), 156 heterozygote AG genotype (102 female, 54 male), and 42 homozygote AA ( 32 female, 10 male). The genotype distribution met Hardy-Weinberg test of equilibrium $x_{(1)}^{2}=1.06, p=.29\left(\right.$ female $x_{(1)}^{2}=3.04, p=.08$; male $\left.x_{(1)}^{2}=0.47, p=.49\right)$. The genotype distribution did not differ as a function of gender, $x^{2}(1)=1.14, p>.05$, and history of psychological disorders, $x_{(2)}^{2}=2.39, p=.68$.

Genotypes were collapsed among carriers of the $\mathrm{G}$ allele (GG/AG), and compared to AA genotypes. In the current sample, both GG and AG genotypes were compared to the AA genotype, who had slightly higher depressive scores and suicide ideation (albeit not significant). This method of collapsing was consistent with previous reports in which $\mathrm{G}$ carriers exhibited 
greater social sensitivity (McQuaid et al., 2015), greater trusting behaviours (Kreuger et al., 2012), reduced cortisol in the presence of social support (Chen et al., 2011), and greater support seeking (Kim et al., 2010). In contrast, the AA genotype was associated with positive affect in adults (Lucht et al., 2009), and superior ability to infer mental states of others (Lucht et al., 2013).

\section{Measures}

\section{Depressive Symptoms}

The 21-item Beck Depression inventory (BDI; Beck, Ward \& Mendelson, 1961) was used to assess depressive symptoms (see Appendix A). Each item reflects a symptom of depression, including pessimism, suicidal ideation, affect, changes in weight and sleep patterns, and anhedonia. Items contain four or five statements of which participants selected the one that most closely reflects how they feel. Total scores are calculated by taking the mean score across all items, with higher scores indicative of greater depressive symptomology $(\alpha=.91)$.

\section{Number of different types of traumas experienced.}

The short version of the Early Life Trauma Inventory (ELTI; Bremner, Bolus \& Mayer, 2007) is a 27-item inventory assessing four types of early life trauma, including general trauma (“Were you ever exposed to a life-threatening natural disaster?"), physical abuse ("Were you ever punched or kicked?”), emotional abuse (“Were you often put down or ridiculed?”), and sexual abuse ("Did you ever experience someone rubbing their genitals against you?). Furthermore, ages of such events were stratified as " 0 to 5", "6 to 12", "13 to 18 ". A 6-point Likert scale was used to measure the frequency of experiencing such events, with 0 representing "Never", up to 5 
representing "More than 10 times". Frequency of early life trauma was calculated by summing all scores, as were summed score for each trauma category (Cronbach's $\alpha=.92)$. Given that the current study was interested in traumas that involved interpersonal exchanges, physical $(\alpha=.85)$, emotional $(\alpha=.92)$, and sexual $(\alpha=.76)$ traumas were summed $(\alpha=.91)$, and general traumas $(\alpha$ $=.79)$ were analyzed separately.

\section{Social Support}

Social Provisions (Cutrona \& Russell, 1987) assessed participants' perceived levels of social support among current relationships (including friends, family, co-workers, etc). This $24-$ item questionnaire used a four-point Likert scale, with values ranging from 1 (Strongly Disagree) to 4 (Strongly Agree). Half of the statements refer to the presence of supportive interactions ("There are people I can depend on to help me if I really need it"), whereas other items were reversely coded and include statements that refer to the absence of social support ("I feel that I do not have close personal relationships with other people"). Scores range from 24 to 96 , with high scores indicative of greater perceptions of social support $(\alpha=.90)$.

\section{Unsupportive Social Interactions}

Unsupportive Social Interactions Inventory (USII; Ingram et al., 2001) was used to assess instances of unsupportive social interactions with friends. This 24 -item inventory comprises four sub-scales that assessed distancing ("would not seem to want to hear about it"), minimizing ("Would try to cheer me up when I was not ready to"), blaming ("Would tell me that I had gotten myself into the situation in the first place, and now must deal with the consequences"), and bumbling ("Would change the subject before I wanted to"). On a five-point Likert scale, 
participants reported the extent to which they have experienced unsupportive social interactions, with values ranging from 0 (none) to 4 (a lot). Scores could range from 0 to 96 , with higher scores indicative of perceiving greater instances of unsupportive social interactions $(\alpha=.93)$.

\section{Rejection Sensitivity}

The Rejection Sensitivity Questionnaire (RSQ; Downey \& Feldman, 1996) was used to measure dispositional sensitivity to rejection. The measure consists of 18 hypothetical interpersonal situations ("you ask someone in class to borrow his/her notes") in which the participant indicates (a) the level of rejection concern ("how concerned or anxious would you be over whether or not the person would want to lend you his or her notes") and measured on a 6point Likert scale from 1 (very unconcerned) to 6 (very concerned), and (b) the level of rejection expectancy ("I would expect that he/she would willingly give me his/her notes") that is measured on a 6-point Likert scale from 1 (very unlikely) to 6 (very likely). To calculate, rejection expectancy (b) is subtracted from 7, then multiplied by rejection concern, followed by the mean score across all 18 items $(\alpha=.90)$.

\section{Statistical Analyses}

Statistical analyses were performed using SPSS for Windows 20.0 (SPSS Science, Chicago, Illinois, USA), with statistical significance determined a $p<.05$. Pearson correlations were used to assess the relations between self-reported scores on measures for depression, suicide ideation, early life trauma, social support, peer unsupportive social interactions, and rejection sensitivity. Differences between genders were performed using independent samples t- 
tests, and differences between genotypes were performed using one-way analyses of variance (ANOVA).

Mediation analyses were conducted using bootstrapping procedures and confidence intervals based on 5000 resamples (Preacher, Rucker \& Hayes, 2007). Interpersonal trauma was treated as an independent variable, depressive scores and suicide ideation were treated as outcome variables, and rejection sensitivity was entered in as a mediator. Furthermore, moderated mediation analyses were conducted using bootstrapping procedures and confidence intervals based on 5000 resamples (Preacher, Rucker \& Hayes, 2007). Unstandardized scores were used for all regression analyses. Beginning with the same mediation analysis, OXTR, perceived social support, and peer unsupport were each entered in as moderators to the indirect pathways. 


\section{Results}

\section{Associations between measures}

Total early life trauma scores were associated with depressive symptoms $(r=.38, p<$ .01 ), however, given that the study focused on social relationships, only interpersonal traumas (emotional, physical, and sexual) were examined. Indeed, interpersonal trauma was more strongly related to depressive symptoms $(r=.36, p<.01)$ than general traumas $(r=.30, p<.01)$. Furthermore, interpersonal trauma was associated with suicide ideation $(r=.30, p<.01)$, and rejection sensitivity $(r=.28, p<.01)$, social support $(r=-.23, p<.01)$, and peer unsupport $(r=$ $.19, p<.01:$ see Table 1).

Gender differences were observed in the current study, with female participants reporting greater depressive symptoms, $t(1,332.73)=5.98, p<.001$, suicide ideation, $t(1,351.76)=4.15$, $p<.000$, rejection sensitivity, $t(1,382)=1.99, p=.047$, and sexual abuse, $t(1,373.42)=2.73, p$ $=.007$. Likewise, female participants reported greater perceived social support, $t(1,382)=1.74$, $p=.082$, and unsupportive bumbling, $t(1,269.63)=1.907, p=.058$, whereas male participants reported greater physical abuse, $t(1,177.05)=-4.34, p=.007$ (see Table 2 for all descriptives and t-tests values). There were no significant differences regarding the OXTR rs53576 genotypes (Table 3 provides a summary of descriptives). 
Table 1. Relations between depressive symptoms, perceived social support, unsupportive social interactions, rejection sensitivity, and early-life trauma.

\begin{tabular}{|c|c|c|c|c|c|c|c|c|c|c|c|}
\hline & 1. & 2. & 3. & 4. & $4 a$. & $4 \mathrm{~b}$. & $4 c$. & $4 \mathrm{~d}$. & 5. & 6. & $6 a$. \\
\hline 1. Depressive Symptoms & 1 & & & & & & & & & & \\
\hline 2. Suicide Ideation & $.65^{* *}$ & 1 & & & & & & & & & \\
\hline 3. Perceived Social Support & $-.49 * *$ & $-.35 * *$ & 1 & & & & & & & & \\
\hline 4. Total Peer Unsupport & $.46^{* *}$ & $.36^{* *}$ & $-.43 * *$ & 1 & & & & & & & \\
\hline a. Distancing & $.46^{* *}$ & $.36^{* *}$ & $-.52 * *$ & $.82 * *$ & 1 & & & & & & \\
\hline b. Bumbling & $.43 * *$ & $.34 * *$ & $-.31 * *$ & $.84 * *$ & $.62 * *$ & 1 & & & & & \\
\hline c. Minimizing & $.29 * *$ & $.21 * *$ & $-.22 * *$ & $.83 * *$ & $.51 * *$ & $.61 * *$ & 1 & & & & \\
\hline d. Blaming & $.35^{* *}$ & $.27 * *$ & $-.37 * *$ & $.83 * *$ & $.59 * *$ & $.56 * *$ & $.59 * *$ & 1 & & & \\
\hline 5. Rejection Sensitivity & $.52 * *$ & $.33 * *$ & $-45 * *$ & $.34 * *$ & $.36 * *$ & $.31 * *$ & $.20 * *$ & $.24 * *$ & 1 & & \\
\hline 6. Early Life Trauma (total) & $.38 * *$ & $.31 * *$ & $-26 * *$ & $.21 * *$ & $.22 * *$ & $.19 * *$ & .09 & $.19 * *$ & $.29 * *$ & 1 & \\
\hline a. General & $.30 * *$ & $.24 * *$ & $-26 * *$ & $.17 * *$ & $.17 * *$ & $.17 * *$ & .07 & $.15 * *$ & $.20 * *$ & $.77 * *$ & 1 \\
\hline b. Interpersonal & $.36^{* *}$ & $.30 * *$ & $-23 * *$ & $.19 * *$ & $.21 * *$ & $.17 * *$ & .08 & $.19 * *$ & $.28 * *$ & $.96 * *$ & $.58 * *$ \\
\hline
\end{tabular}

$* * p<.01$

$* p<.05$ 
Table 2. Mean, Standard Error, $t$-test $p$-values of study variables by gender

\begin{tabular}{|c|c|c|c|}
\hline & $\begin{array}{c}\text { Female } \\
(n=266)\end{array}$ & $\begin{array}{c}\text { Male } \\
(n=118)\end{array}$ & t-test \\
\hline 1. Depressive Symptoms & $\begin{array}{l}M=11.20 \\
S E=0.56\end{array}$ & $\begin{array}{l}M=6.50 \\
S E=0.54\end{array}$ & $\begin{array}{c}t(1,332.73)=5.98 \\
p<0.001^{*}\end{array}$ \\
\hline 2. Suicide Ideation & $\begin{array}{l}M=0.35 \\
S E=0.04\end{array}$ & $\begin{array}{l}M=0.14 \\
S E=0.03\end{array}$ & $\begin{array}{c}t(1,351.76)=4.15 \\
p<0.001^{*}\end{array}$ \\
\hline 3. Perceived Social Support & $\begin{array}{l}M=3.43 \\
S E=0.02\end{array}$ & $\begin{array}{l}M=3.35 \\
S E=0.04\end{array}$ & $\begin{array}{c}t(1,382)=1.74 \\
p=0.08\end{array}$ \\
\hline 4. Total Peer Unsupport & $\begin{array}{l}M=1.44 \\
S E=0.05\end{array}$ & $\begin{array}{l}M=1.40 \\
S E=0.06\end{array}$ & $\begin{array}{c}t(1,270.914)=0.534 \\
p=0.59^{*}\end{array}$ \\
\hline a. Distancing & $\begin{array}{l}M=1.10 \\
S E=0.07\end{array}$ & $\begin{array}{l}M=0.98 \\
S E=0.07\end{array}$ & $\begin{array}{c}t(1,258.491)=1.269 \\
p=0.21^{*}\end{array}$ \\
\hline b. Bumbling & $\begin{array}{l}M=1.51 \\
S E=0.05\end{array}$ & $\begin{array}{l}M=1.35 \\
S E=0.07\end{array}$ & $\begin{array}{c}t(1,69.63)=1.907 \\
p=0.06^{*}\end{array}$ \\
\hline c. Minimizing & $\begin{array}{l}M=2.12 \\
S E=0.06\end{array}$ & $\begin{array}{l}M=2.12 \\
S E=0.08\end{array}$ & $\begin{array}{c}t(1,261.149)=0.023 \\
p=0.98^{*}\end{array}$ \\
\hline d. Blaming & $\begin{array}{l}M=1.03 \\
S E=0.06\end{array}$ & $\begin{array}{l}M=1.16 \\
S E=0.07\end{array}$ & $\begin{array}{c}t(1,382)=-1.295 \\
p=0.20\end{array}$ \\
\hline 5. Rejection Sensitivity & $\begin{array}{l}M=9.68 \\
S E=0.27\end{array}$ & $\begin{array}{l}M=8.72 \\
S E=0.38\end{array}$ & $\begin{array}{c}t(1,382)=1.99 \\
p=0.05\end{array}$ \\
\hline 6. Early Life Trauma (total) & $\begin{array}{l}M=27.49 \\
S E=1.71\end{array}$ & $\begin{array}{l}M=27.25 \\
S E=2.09\end{array}$ & $\begin{array}{c}t(1,272.201)=0.092 \\
p=0.93\end{array}$ \\
\hline a. General & $\begin{array}{l}M=8.37 \\
S E=0.55\end{array}$ & $\begin{array}{l}M=7.19 \\
S E=0.66\end{array}$ & $\begin{array}{c}t(1,275.454)=1.378 \\
p=0.17^{*}\end{array}$ \\
\hline b. Interpersonal & $\begin{array}{l}M=19.06 \\
S E=1.32\end{array}$ & $\begin{array}{l}M=20.17 \\
S E=1.71\end{array}$ & $\begin{array}{c}t(1,382)=-0.513 \\
p=0.63\end{array}$ \\
\hline i. Emotional & $\begin{array}{l}M=11.91 \\
S E=0.89\end{array}$ & $\begin{array}{l}M=9.88 \\
S E=1.05\end{array}$ & $\begin{array}{c}t(1,283.954)=1.475 \\
p=0.13^{*}\end{array}$ \\
\hline
\end{tabular}



ii. Physical

$$
\begin{array}{ccc}
M=4.80 & M=9.03 & t(1,177.05)=-4.34 \\
S E=0.44 & S E=0.87 & p<0.001^{*}
\end{array}
$$
iii. Sexual

$$
\begin{array}{ccc}
M=2.39 & M=1.29 & t(1,373.42)=2.73 \\
S E=0.32 & S E=0.25 & p=0.01^{*}
\end{array}
$$

When Levene's test of Equality of Variances was violated, not assumed are reported.

* Violated Leven's Test of Equality of Variance 
Table 3. Mean, Standard Error, ANOVA $p$-values of study variables by OXTR rs53576 genotype.

\begin{tabular}{|c|c|c|c|c|}
\hline & \multicolumn{4}{|c|}{ OXTR } \\
\hline & $\begin{array}{c}\mathrm{GG} \\
(n=186)\end{array}$ & $\begin{array}{c}\mathrm{AG} \\
(n=156)\end{array}$ & $\begin{array}{c}\text { AA } \\
(n=42)\end{array}$ & $F$-value \\
\hline \multirow{2}{*}{ 1. Depressive Symptoms } & $M=9.85$ & $M=9.38$ & $M=10.74$ & $F(2,381)=0.43$, \\
\hline & $S E=0.67$ & $S E=0.64$ & $S E=1.31$ & $p=0.65$ \\
\hline \multirow{2}{*}{ 2. Suicide Ideation } & $M=0.28$ & $M=0.27$ & $M=0.33$ & $F(2,380)=0.20$, \\
\hline & $S E=0.04$ & $S E=0.05$ & $S E=0.10$ & $p=0.82$ \\
\hline \multirow{2}{*}{ 3. Perceived Social Support } & $M=3.40$ & $M=3.40$ & $M=3.44$ & $F(2,381)=0.23$, \\
\hline & $S E=0.03$ & $S E=0.03$ & $S E=0.05$ & $p=0.79$ \\
\hline \multirow{2}{*}{ 4. Total Peer Unsupport } & $M=1.46$ & $M=1.41$ & $M=1.37$ & $F(2,381)=0.27$ \\
\hline & $S E=0.05$ & $S E=0.06$ & $S E=0.11$ & $p=0.76$ \\
\hline \multirow{2}{*}{ a. Distancing } & $M=1.05$ & $M=1.07$ & $M=1.11$ & $F(2,381)=0.07$ \\
\hline & $S E=0.07$ & $S E=0.07$ & $S E=0.15$ & $p=0.93$ \\
\hline \multirow{2}{*}{ b. Bumbling } & $M=1.53$ & $M=1.42$ & $M=1.35$ & $F(2,381)=1.12$, \\
\hline & $S E=0.06$ & $S E=0.07$ & $S E=0.12$ & $p=0.33$ \\
\hline \multirow{2}{*}{ c. Minimizing } & $M=2.14$ & $M=2.11$ & $M=2.05$ & $F(2,381)=0.18$ \\
\hline & $S E=0.07$ & $S E=0.08$ & $S E=0.13$ & $p=0.84$ \\
\hline \multirow{2}{*}{ d. Blaming } & $M=1.10$ & $M=1.06$ & $M=0.99$ & $F(2,381)=0.31$ \\
\hline & $S E=0.06$ & $S E=0.07$ & $S E=0.21$ & $p=0.74$ \\
\hline \multirow{2}{*}{ 5. Rejection Sensitivity } & $M=9.57$ & $M=9.09$ & $M=9.64$ & $F(2,381)=0.19$ \\
\hline & $S E=0.34$ & $S E=0.31$ & $S E=0.79$ & $p=0.55$ \\
\hline \multirow{2}{*}{ 6. Early Life Trauma (total) } & $M=27.63$ & $M=26.64$ & $M=29.33$ & $F(2,381)=0.43$, \\
\hline & $S E=1.90$ & $S E=2.10$ & $S E=4.44$ & $p=0.83$ \\
\hline \multirow{2}{*}{ a. General } & $M=8.30$ & $M=7.87$ & $M=7.19$ & $F(2,381)=0.33$ \\
\hline & $S E=0.60$ & $S E=0.71$ & $S E=1.25$ & $p=0.72$ \\
\hline \multirow{2}{*}{ b. Interpersonal } & $M=19.16$ & $M=18.91$ & $M=22.29$ & $F(2,381)=0.46$ \\
\hline & $S E=1.49$ & $S E=1.61$ & $S E=3.77$ & $p=0.63$ \\
\hline \multirow{2}{*}{ i. Emotional } & $M=11.82$ & $M=10.37$ & $M=12.33$ & $F(2,381)=0.61$, \\
\hline & $S E=0.97$ & $S E=1.12$ & $S E=2.26$ & $p=0.54$ \\
\hline ii. Physical & $M=5.39$ & $M=6.47$ & $M=7.86$ & $F(2,381)=1.87$ \\
\hline
\end{tabular}


iii. Sexual***

$$
\begin{array}{cccc}
S E=0.54 & S E=0.67 & S E=1.57 & p=0.16 \\
M=2.05 & M=2.08 & M=1.93 & F(2,381)=0.02, \\
S E=0.37 & S E=0.34 & S E=0.59 & p=0.98
\end{array}
$$

*** Values not brought into range

Pairwise deletion 


\section{Mediating role of rejection sensitivity}

It was of interest to examine whether the relationship between interpersonal trauma and depression was mediated by rejection sensitivity. A mediation analysis was conducted using bootstrapping techniques based of 5000 resamples to determine $95 \%$ confidence intervals (Preacher \& Hayes, 2004) to examine whether rejection sensitivity partially explained the relationship between interpersonal trauma and depression. As predicted, rejection sensitivity mediated the relationship between interpersonal trauma and depressive symptoms $(95 \% \mathrm{CI}$ $\{0.031,0.081\})$; however, the relationship between interpersonal trauma and depressive scores remained significant, $b=0.095, p<.001$. In a similar model, in which suicide ideation replaced depressive scores, rejection sensitivity again mediated the relationship between interpersonal trauma and suicide ideation $(95 \%$ CI $\{0.001,0.004\})$, however, the relationship between interpersonal trauma and suicide ideation remained significant, $b=0.006, p<.001$.

\section{Moderated Mediation Analysis}

To examine whether OXTR genotype influenced the mediation analyses above, a moderated mediation analysis was performed using bootstrapping procedure based of 5000 resamples to determine 95\% confidence (Preacher \& Hayes, 2004). As expected, the OXTR gene moderated the mediation pathway between interpersonal trauma and rejection sensitivity, in relation to depressive scores, $b=0.07, t=2.30, p=.02$ (Figure 1a). Specifically, Figure 1b shows the relationship between interpersonal trauma and rejection sensitivity was found only among AA carriers. In a similar model in which total depressive scores was replaced with suicide ideation (Figure 1c), parallel findings were found in regards to OXTR moderating the mediation pathway between interpersonal trauma and rejection sensitivity, $b=0.07, t=2.30, p=.02$. 
Specifically, the relationship between interpersonal trauma and rejection sensitivity was stronger among AA carriers. In contrast, the relationship between rejection sensitivity and suicide ideation was not moderated by OXTR, $b=-0.001, t=-0.07, p=.96$. 


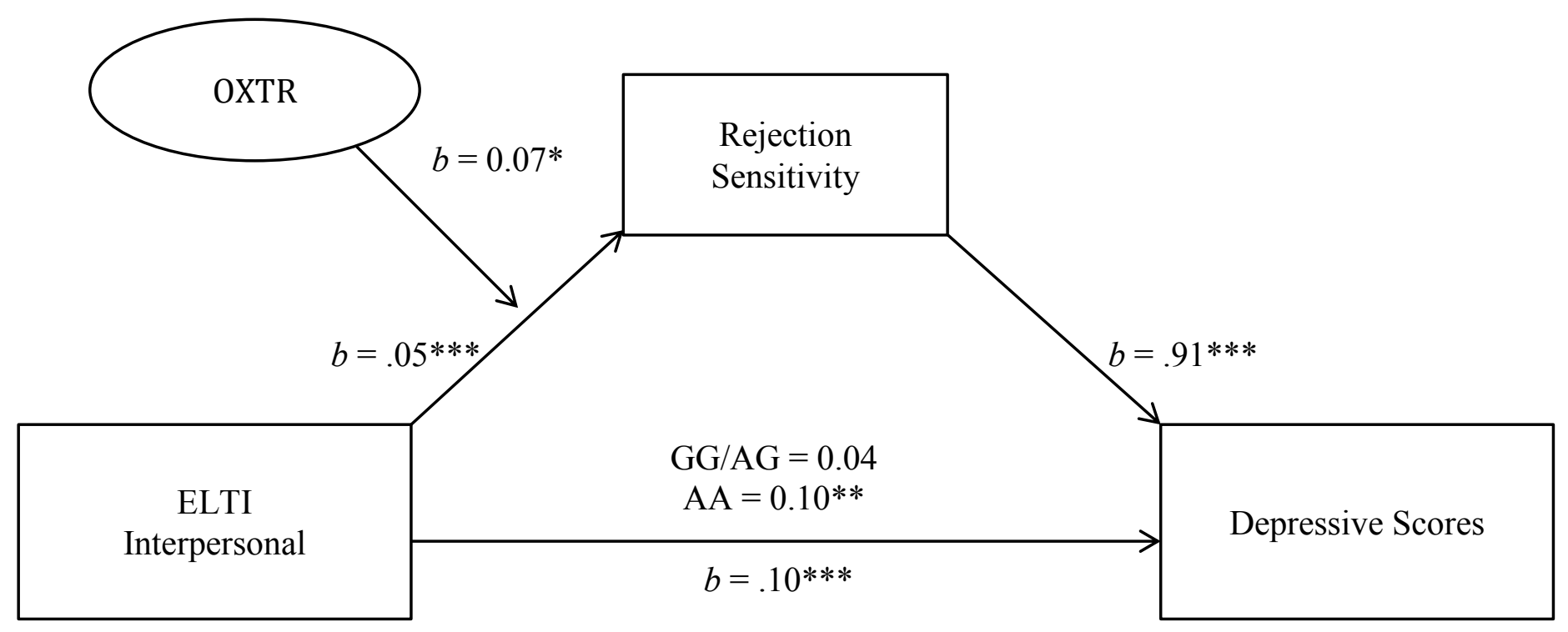

Figure 1a. Schematic overview of the moderated mediation analysis between interpersonal trauma and depressive scores through rejection sensitivity was moderated by the OXTR rs53576 genotype. The pathway between interpersonal trauma and rejection sensitivity was stronger for AA carriers. ${ }^{*} p \leq .05,{ }^{* *} p \leq .01,{ }^{* * *} p \leq .001$ 


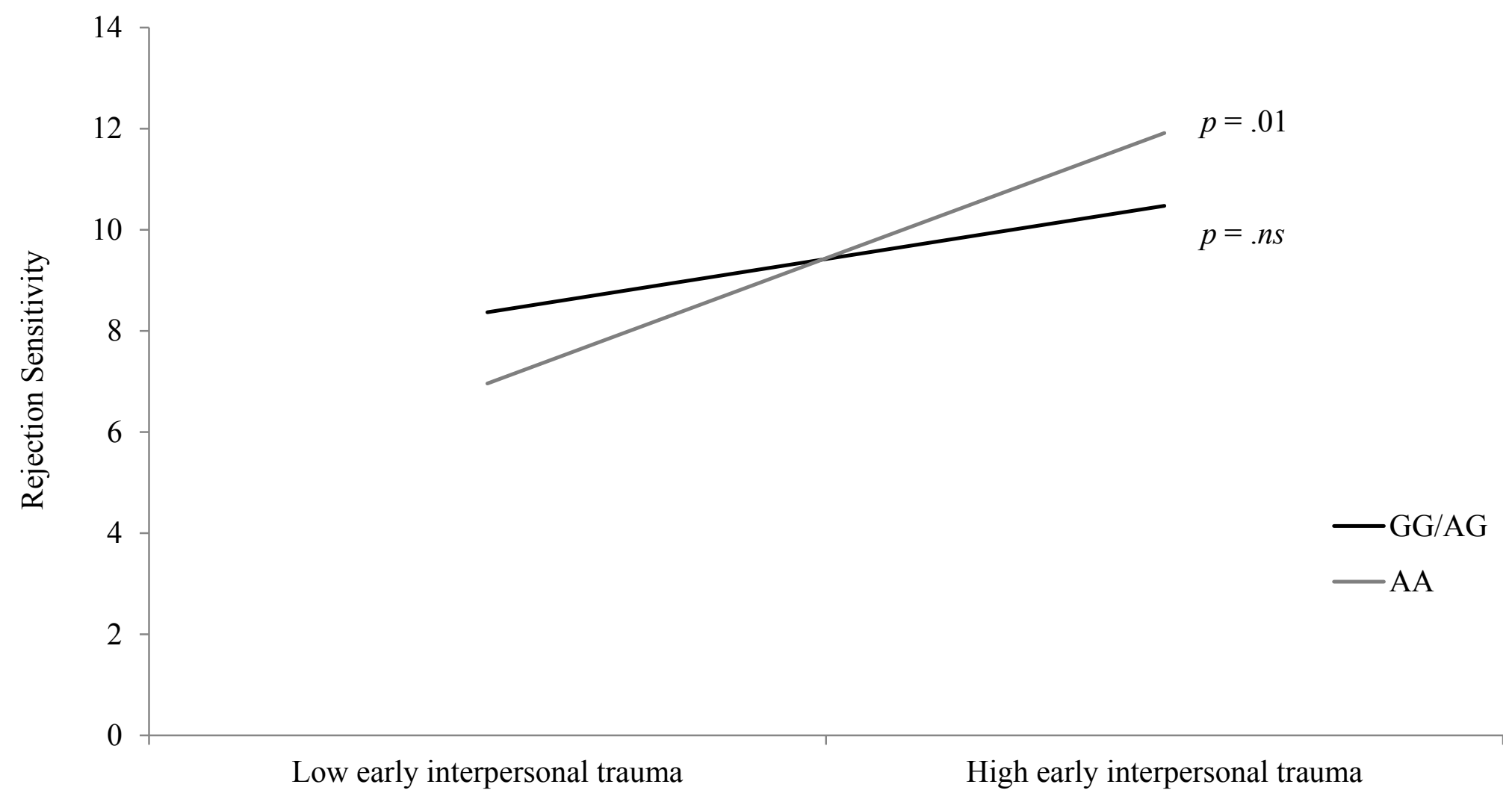

Figure $1 \mathrm{~b}$. The relationship between interpersonal trauma and rejection sensitivity as a function of OXTR rs53576 genotype (GG/AG vs. AA). Simple slopes analysis revealed that rejection sensitivity increased with greater interpersonal trauma, however only among AA genotypes. 


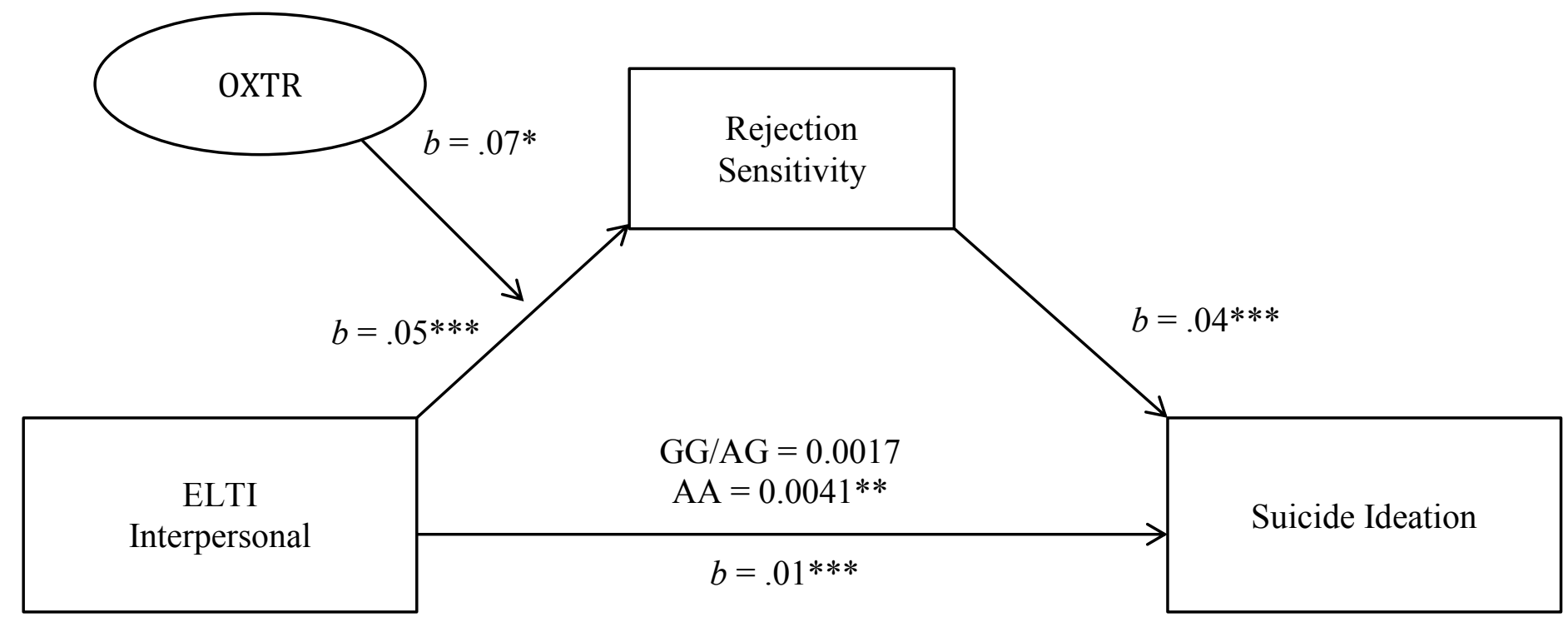

Figure 1c. Schematic overview of the moderated mediation analysis of which interpersonal trauma and suicide ideation was mediated through rejection sensitivity, and moderated by the OXTR rs53576 genotype. The relationship between interpersonal trauma and rejection sensitivity was stronger for AA carriers. ${ }^{*} p \leq .05,{ }^{* *} p \leq .01,{ }^{* * *} p \leq .001$ 


\section{Buffering role of social support}

Given the psychosocial nature of interpersonal trauma and rejection sensitivity in relation to depressive scores, it was of interest to determine whether perceived social support moderated the mediation pathway. Specifically, a moderated mediation analysis was conducted using bootstrapping procedures and confidence intervals based on 5000 resamples. As predicted, perceived social support moderated the relationship between rejection sensitivity and depressive scores, $(b=-0.41, t=-2.35, p=.02$ (see Figure 2a), such that the relationship between rejection sensitivity and depressive scores was stronger among individuals with lower perceived social support (see figure $2 b$ ). In an alternative model, perceived social support did not moderate the indirect pathway between interpersonal trauma and rejection sensitivity, $b=0.03, t=1.47, p=$ .14 .

At a more extreme measure of depressive symptoms, suicide ideation replaced depressive scores in the moderated mediation analysis. Again, perceived social support moderated the relationship between rejection sensitivity and suicide ideation within the mediation analysis $(b=$ $-0.04, t=-3.33, p=.001$ (Figure 2c). A significant effect was found among low perceived social support in relation to rejection sensitivity and suicide ideation, whereas no significant effect was found among individuals reporting greater perceived social support (Figure 2d). 


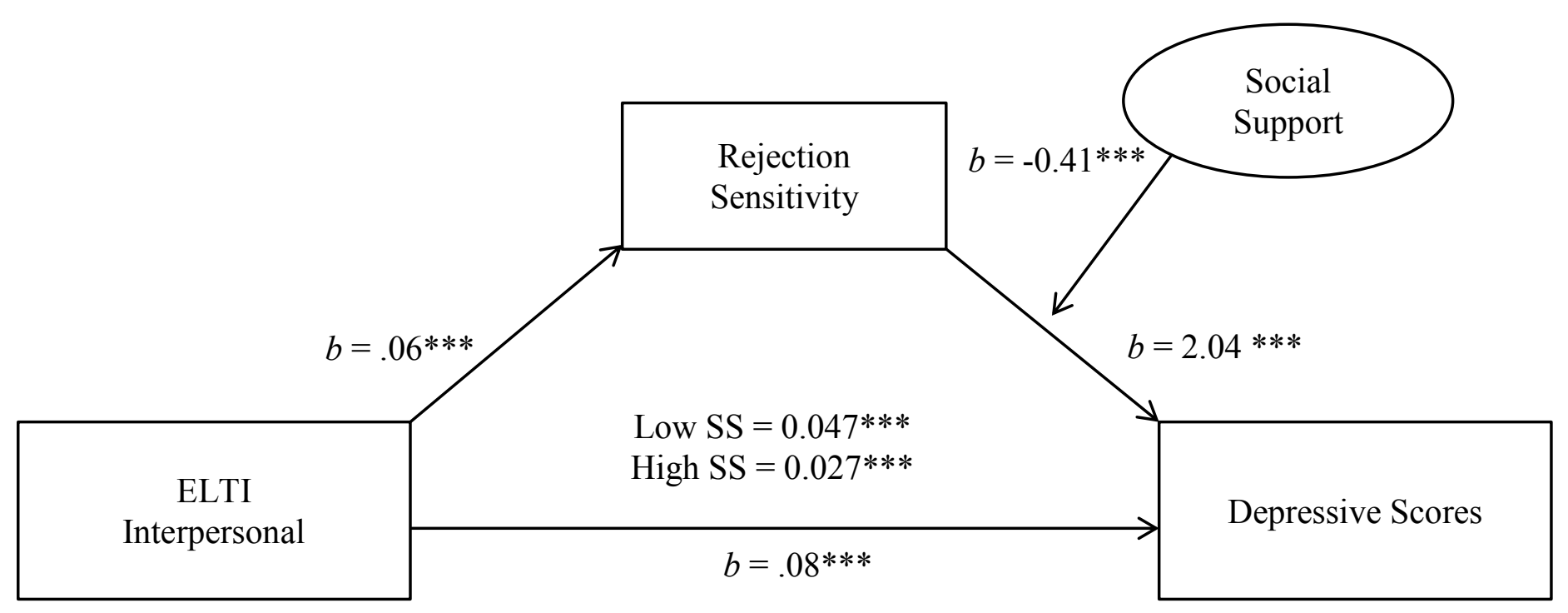

Figure 2a. Schematic representation of the moderated mediation analysis of rejection sensitivity mediating the relationship between interpersonal trauma and depressive scores, and moderated by perceived social support. The relationship between rejection sensitivity and depressive scores was stronger among individuals with lower perceived social support. ${ }^{*} p \leq .05, * * p \leq .01,{ }^{* * *} p \leq .001$ 


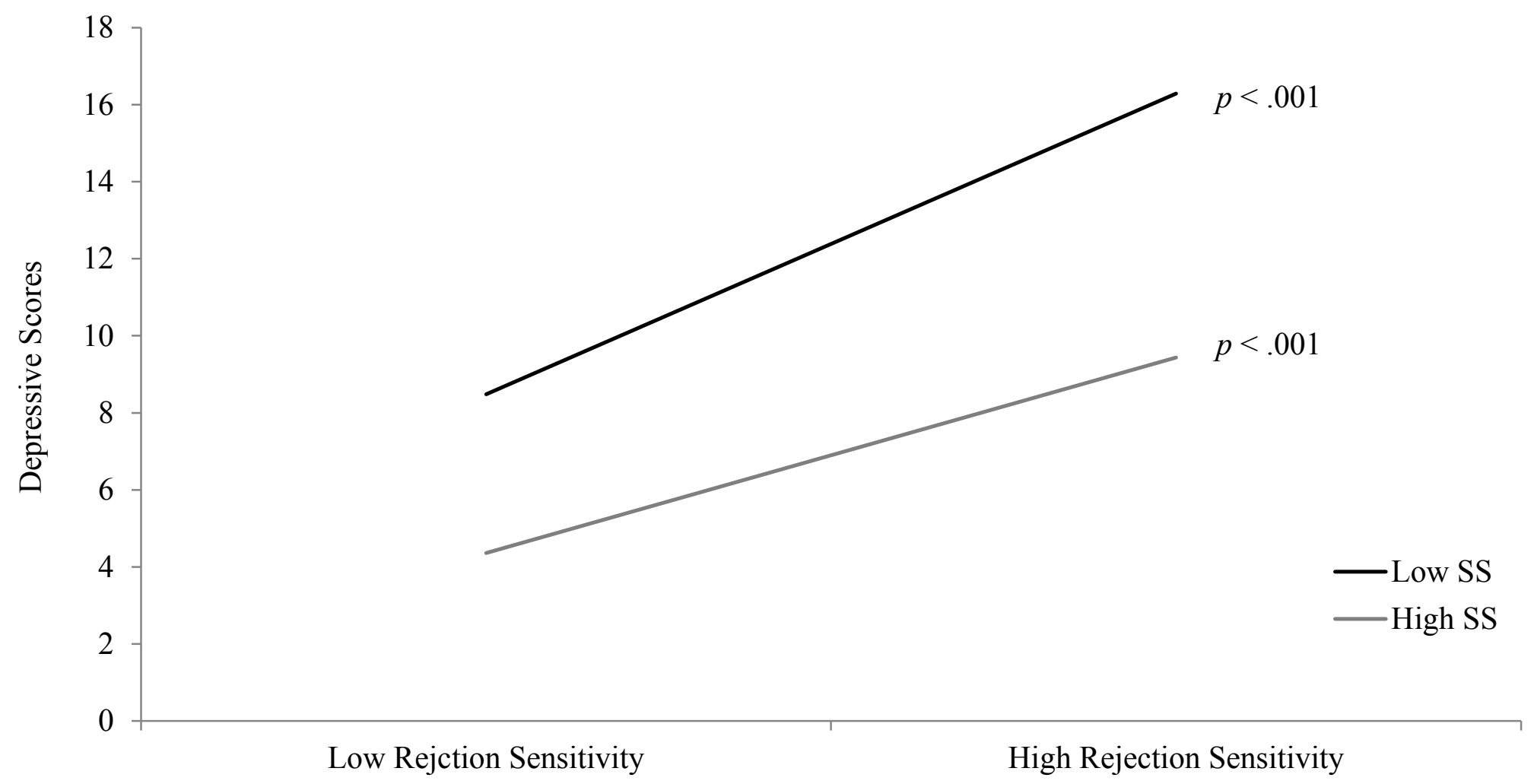

Figure $2 b$. The moderating role of perceived social support in relation between rejection sensitivity and depressive symptoms. Simple slopes analysis revealed that depressive symptoms increased with greater rejection sensitivity, however the effect was stronger among individuals with lower perceived social support. 


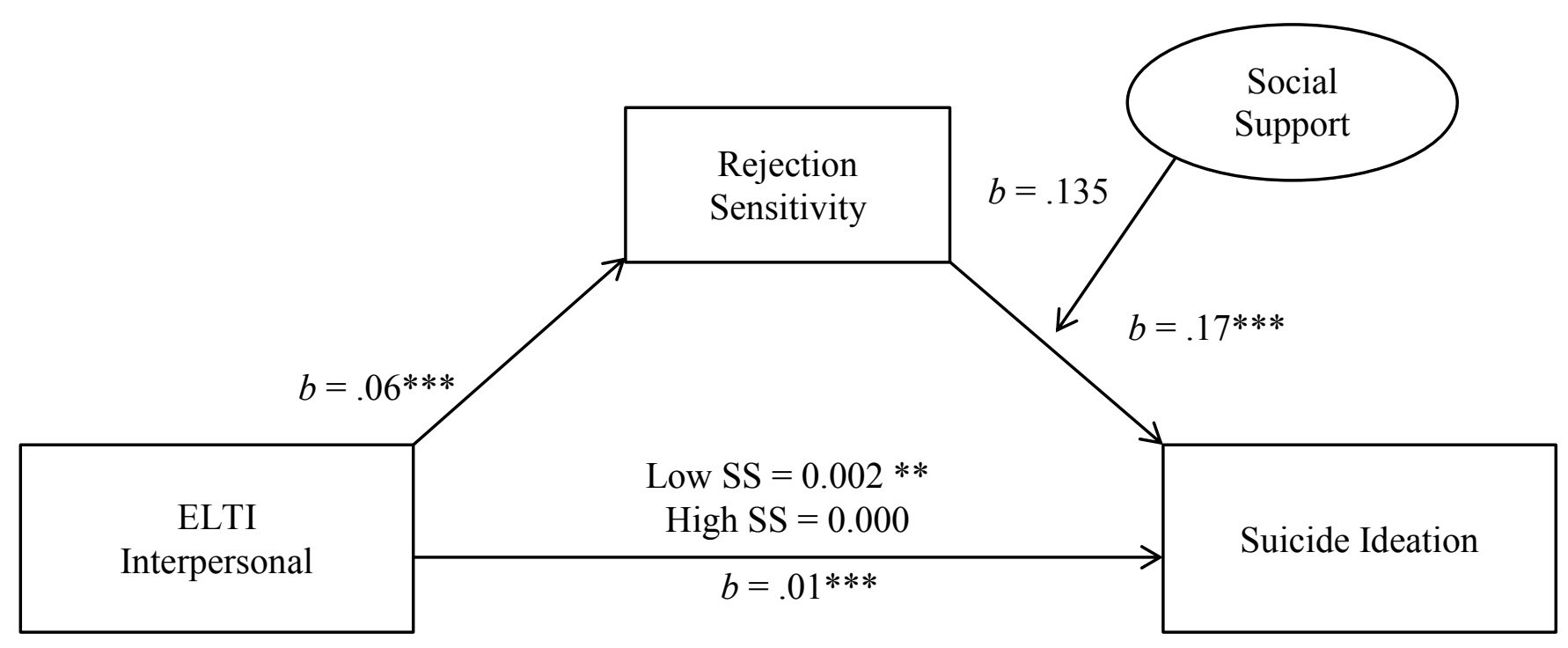

Figure 2c. Schematic depiction of the moderated mediation analysis. Interpersonal trauma and suicide ideation was mediated through rejection sensitivity, and moderated by perceived social support. The relationship between rejection sensitivity was stronger and suicide ideation was stronger among individuals with lower perceived social support. ${ }^{*} p \leq .05,{ }^{* *} p \leq .01,{ }^{* * *} p \leq .001$ 


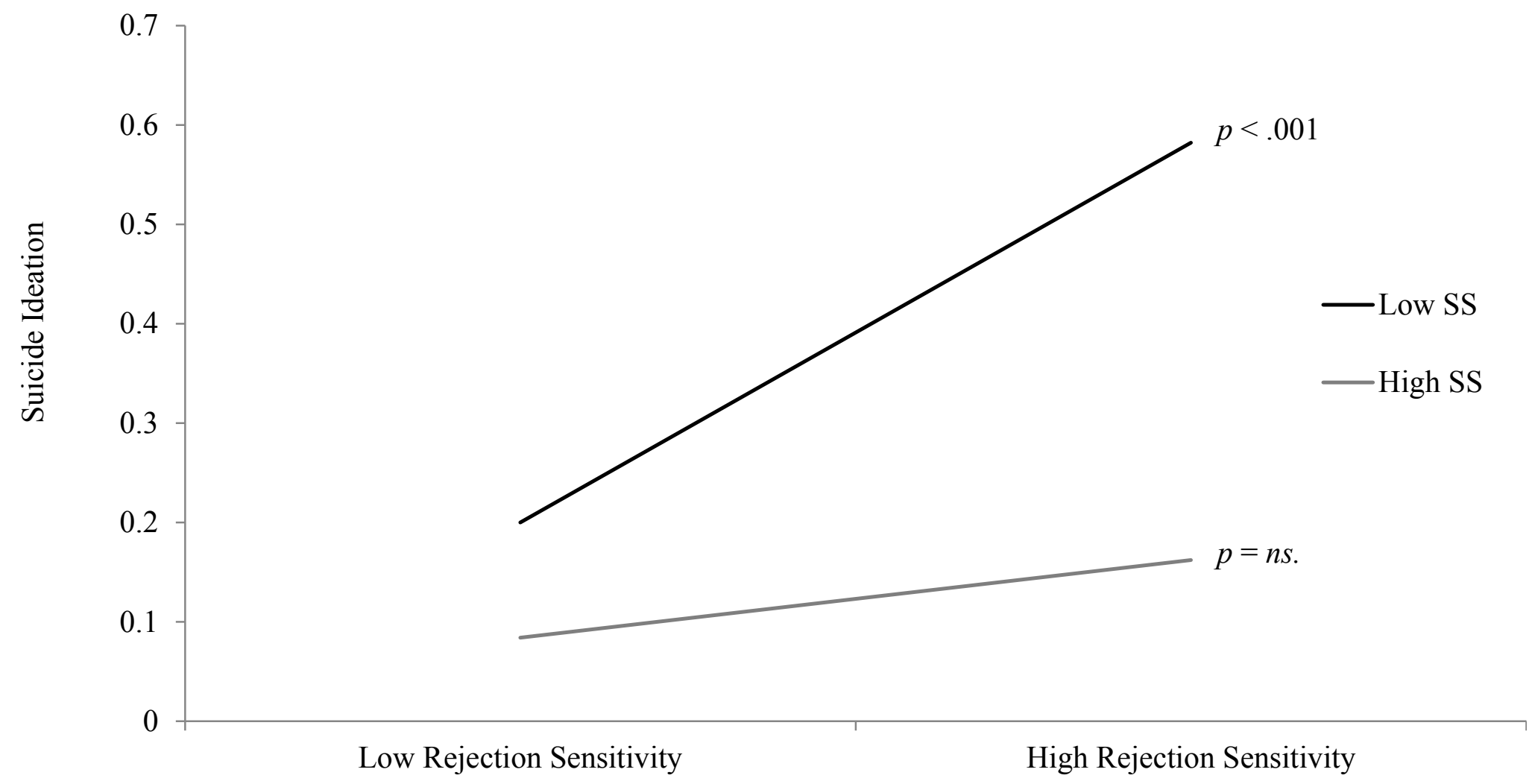

Figure $2 \mathrm{~d}$. The interaction between rejection sensitivity and social support on suicide ideation. Simple slopes analysis revealed that the relationship between rejection sensitivity and suicide ideation was only evident among individuals with lower perceived social support. 


\section{Unsupportive social interactions}

Alternatively, unsupportive social interactions from peer appeared more detrimental in relation to depressive symptoms and suicide ideation. Beginning with the same mediation analyses of rejection sensitivity mediating interpersonal trauma and depressive symptoms or suicide ideation, unsupportive social interactions were entered in as a moderator between rejection sensitivity and depressive outcomes. As seen in Figure 3a, a near-significant interaction between rejection sensitivity and peer unsupport in relation to depressive scores, $b=0.18, t=$ $1.72, p=.09$. Specifically, the relationship between rejection sensitivity and depressive scores was stronger among individuals who have experienced higher instances of unsupport from peers (Figure 3b). Moreover, the relationship between rejection sensitivity and suicide ideation was moderated by peers unsupport, $b=0.02, t=1.89, p=.06$ (Figure $3 \mathrm{c}$ ). Specifically, the association between rejection sensitivity and suicide ideation was stronger among individuals who experience higher unsupport from peers (Figure 3d). 


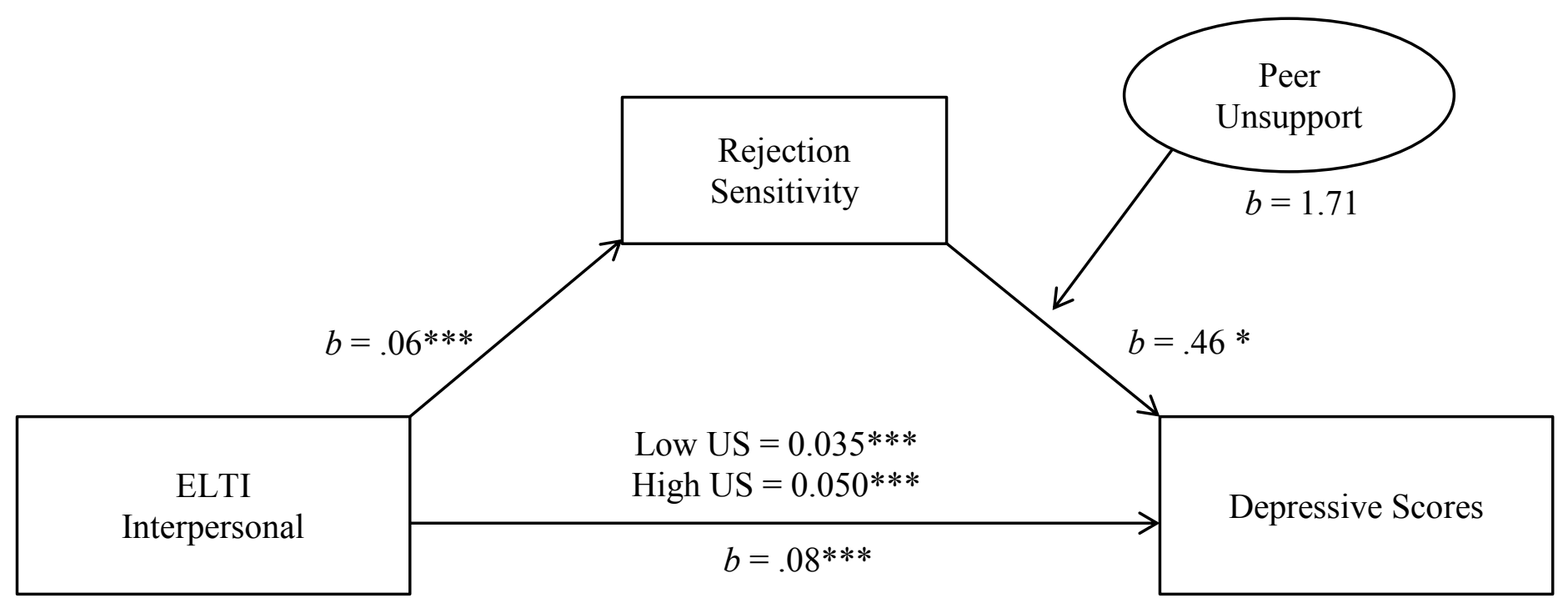

Figure 3a. Schematic representation of the moderated mediation relationship in which interpersonal trauma and depressive scores was mediated through rejection sensitivity, and moderated by peer unsupport. The relationship between rejection sensitivity and depressive scores was stronger among individuals with greater peer unsupport. $* p \leq .05, * * p \leq .01, * * * p \leq .001$ 


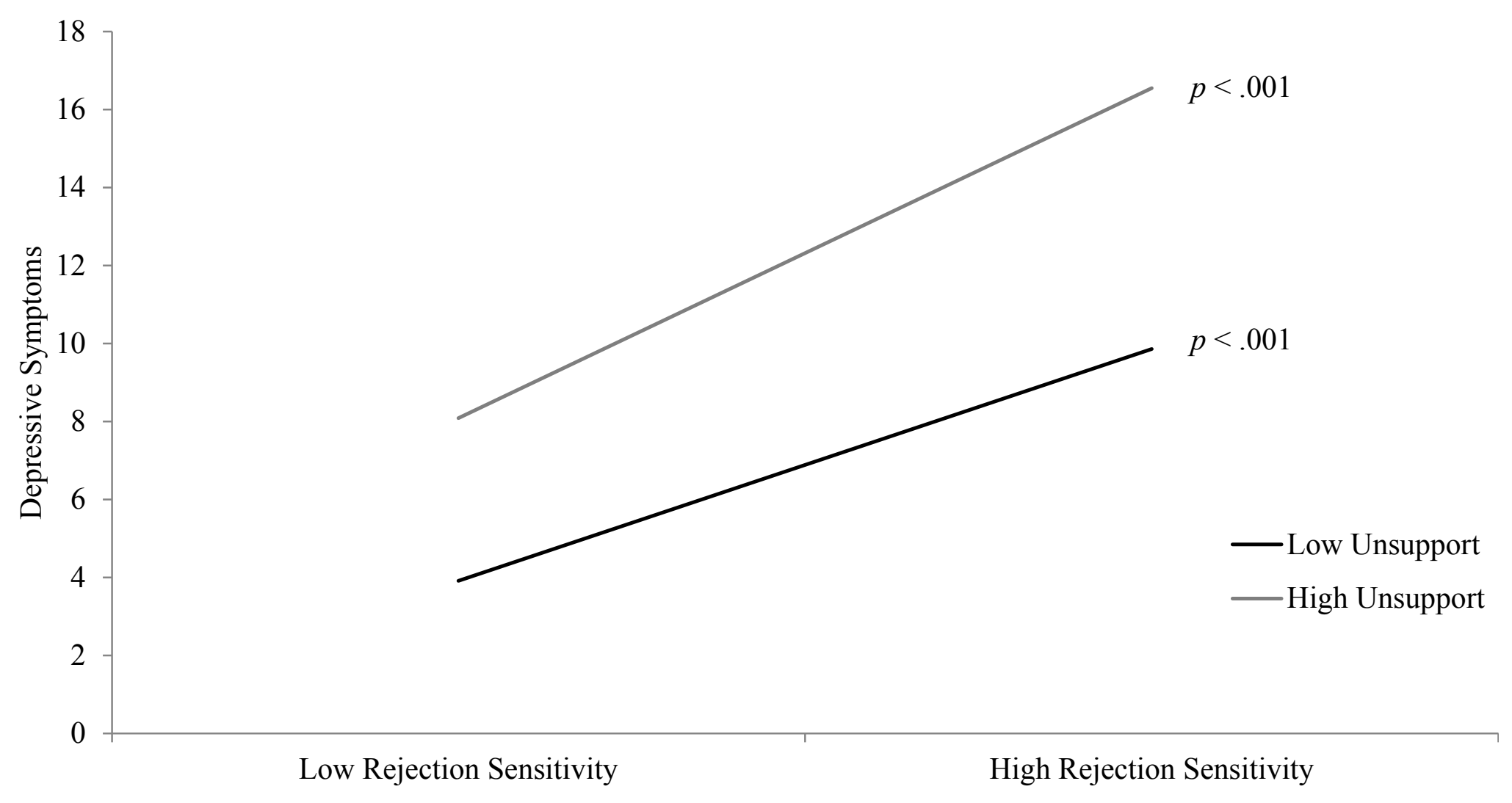

Figure 3b. The moderating role of peer unsupport in relation between rejection sensitivity and depressive symptoms. Simple slopes analysis revealed that depressive symptoms increased with greater rejection sensitivity, however the effect was stronger among individuals with greater peer unsupport. 


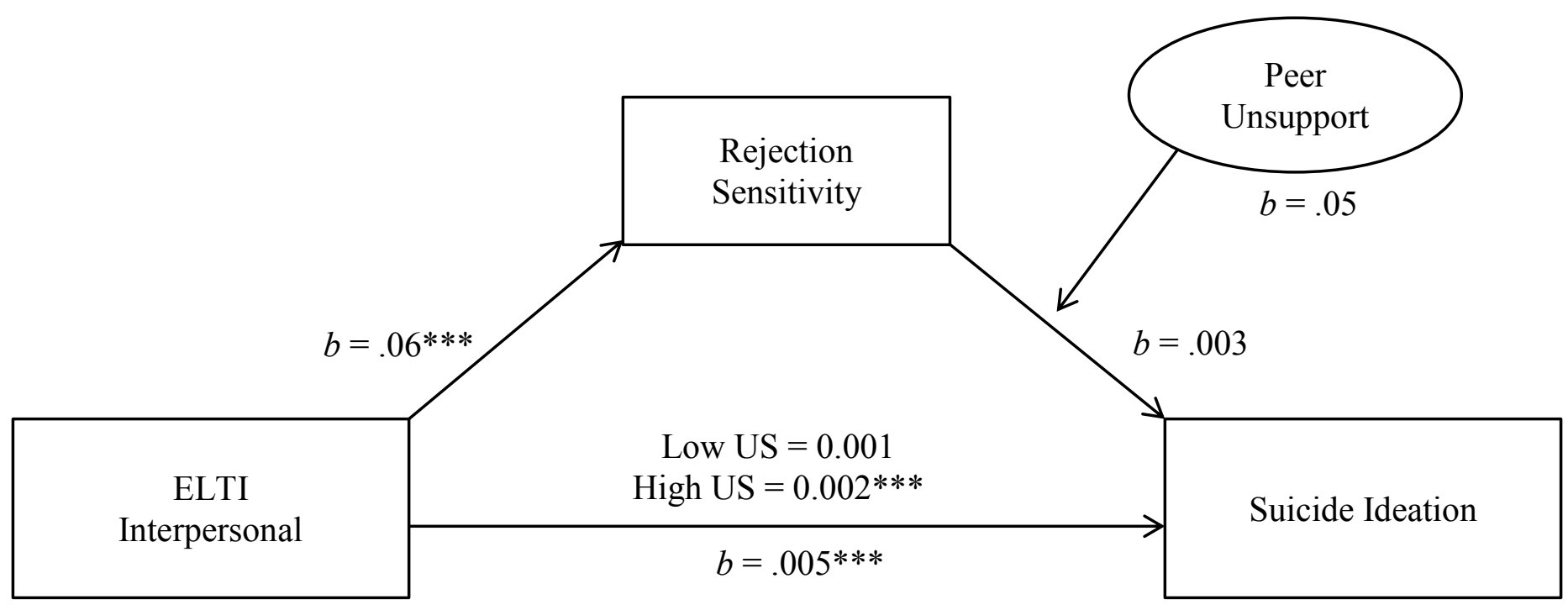

Figure 3c. Schematic depiction of the moderated mediation analysis. Interpersonal trauma and suicide ideation was mediated through rejection sensitivity, and moderated by peer unsupport. The relationship between rejection sensitivity and suicide ideation was stronger among individuals with greater peer unsupport. ${ }^{*} p \leq .05,{ }^{* *} p \leq .01,{ }^{* * *} p \leq .001$ 


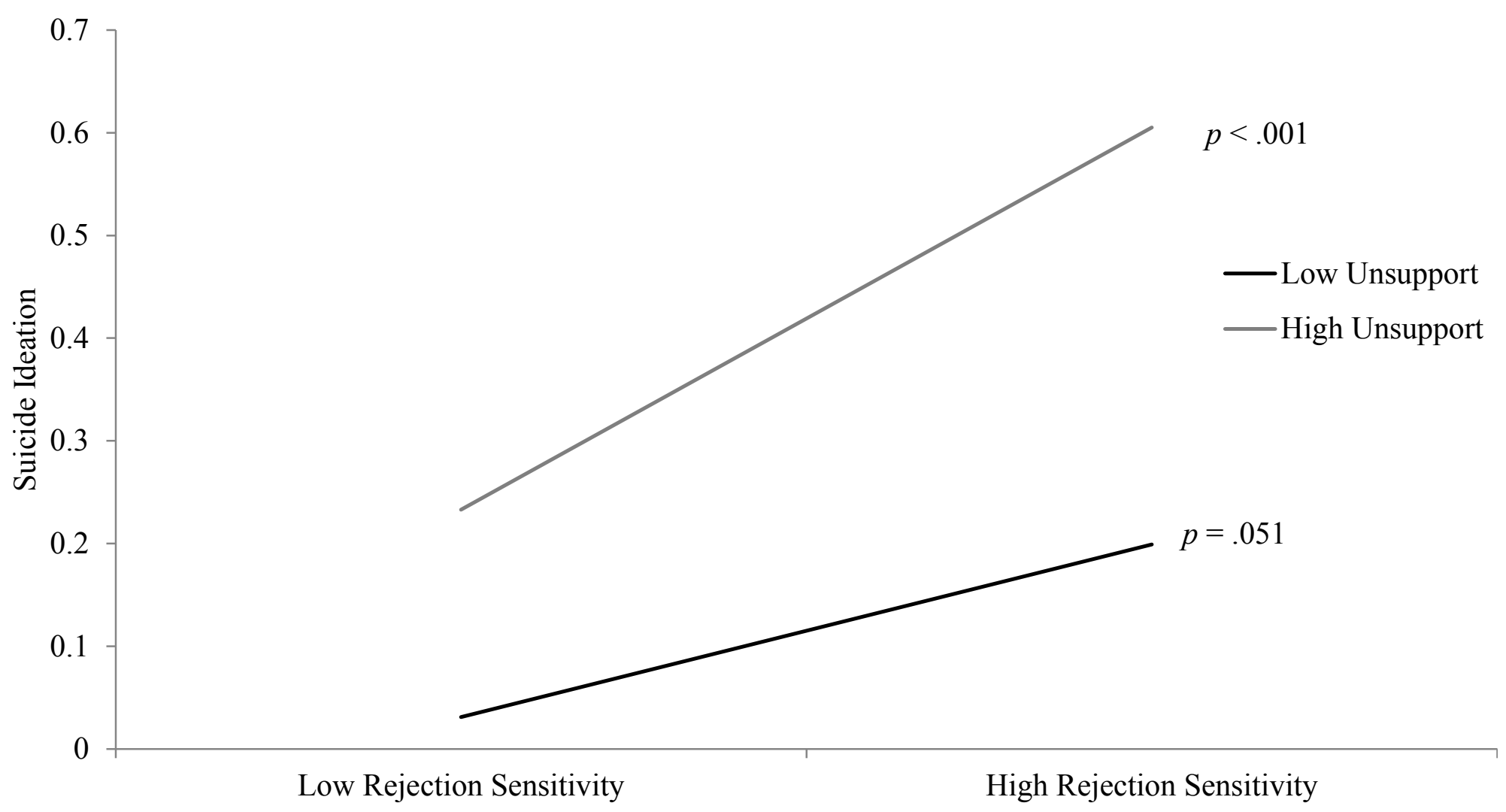

Figure 3d. The moderating role of peer unsupport in relation between rejection sensitivity and suicide ideation. Simple slopes analysis revealed that suicide ideation increased with greater rejection sensitivity, however the effect was stronger among individuals with greater peer unsupport. 


\section{Discussion}

In the current investigation, interpersonal trauma that occurred prior to 17 years of age was related to depressive symptoms and suicide ideation, and these relationships were mediated by rejection sensitivity. Furthermore, the OXTR polymorphism rs53576 moderated the relationship between interpersonal trauma and rejection sensitivity. Specifically, the link between trauma experiences and rejection sensitivity was only evident among those with the AA genotype. In effect, individuals with the AA genotype who experienced earlier interpersonal trauma might have a disposition that is sensitive to rejection, which contributes to greater depressive scores. Of course, it is uncertain whether a causal connection exists in this regard, and indeed, rejection sensitivity could be provocative in relation to depression, or alternatively be a characteristic feature of depressive illness. In fact, one of the features of atypical depressive illness is their persistent rejection sensitivity, even during well periods (Ravindran et al., 2002).

The current findings indicated that in relation to interpersonal trauma, rejection sensitivity was tied to greater depressive scores, and this was particularly apparent among individuals with low perceived support. Thus, the combination of heightened sensitivity to rejection and low perceived social support has detrimental outcomes on mental health, although, once again, causation cannot be inferred in the current study. Furthermore, the link between rejection sensitivity and suicide ideation was particularly pronounced, and as expected this relationship was only present among individuals with low perceived social support. It is possible that with little social resources and a fear of rejection, individuals might see limited options in minimizing their distress other than thoughts of suicide, whereas social support can buffer distress associated with rejection, and thus is tied to diminished suicidal thoughts. Again, these data are only correlational, thus precluding causal conclusions. 
Lastly, the current study indicated that in relation to interpersonal trauma, rejection sensitivity was tied to greater depressive scores, and this was particularly apparent among individuals with higher unsupportive social interaction. In essence, individuals experiencing high unsupportive relationships who are sensitive to rejection, might display especially high depressive scores, as well as suicide ideation (McQuaid, Bombay, McInnis, Matheson \& Anisman, 2015). Given the nature of rejection-sensitive individuals' expectancy, perceptiveness, and overreaction to rejection, unsupportive social interactions might cut that much more deeply.

\section{Trauma, Rejection, and Depression}

Consistent with previous studies that demonstrated a dose-dependent response between traumatic events and adverse outcomes (De Marco, 2000; Dunn, McLaughlin, Slopen, Rosand \& Smoller, 2013; Edwards, Holden, Felitti \& Anda, 2003; Silverman, Reinherz \& Giaconia, 1996), interpersonal trauma predicted both depressive symptoms and suicide ideation. However, in the present study, as in many others (Bruffaerts et al., 2010; De Carvalho Tofoli, Von Werne Baes, Martins \& Juruena, 2011; Lopez-Castroman et al., 2013), interpersonal trauma was reported retrospectively, and therefore might not be an accurate measure of trauma experienced. Among other things, this relationship might stem from a negative cognitive bias common among individuals with depression (Amann, 1991; Everaert, Koster \& Derakshan, 2012; Lakey \& Cassady 1990). At the same time, this negative bias might be accounted for by a heightened sensitivity to rejection, as the current investigation demonstrated that rejection sensitivity mediated the relationship between early interpersonal trauma and depression (Downey \& Feldman, 1996). Given that interpersonal trauma can lead to feelings of rejection, especially if such behaviours are recurring or chronic (Downey, Khouri \& Feldman, 1997), individuals might 
develop an expectancy of rejection in similar contexts, or feelings of rejection might be incorporated into the individuals self-schema so that it becomes a trait characteristic.

Consequently, high rejection sensitivity individuals display maladaptive coping (Ravindran, 2002), poor self-esteem (Murray, Griffin, Rose \& Bellavia, 2003), self-efficacy (Watson \& Nesdale, 2012), as well as heightened depressive symptoms (Ayduk, Downey \& Kim, 2001).

Having been bitten once by rejection from close family members and friends, rejectionsensitive individuals might become hypervigilent to the possibility of further rejection. Defensive behaviours related to rejection sensitivity might contribute to a self-perpetuating cycle, or selffulfilling prophecy, that undermines current social relationships and impedes the development of new social networks (Downey, Khouri \& Feldman, 1997). In such circumstances, perceived and actual rejection is met with exaggerated responses, such as aggression (Ayduk, Gyurak \& Luerrsen, 2008) or jealousy (Downey \& Feldman, 1996). However, it is also common for rejection-sensitive individuals to avoid rejection by undervaluing their own needs for the sake of another (Harper, Dickson \& Welsh, 2006). This is particularly common in romantic relationships, in which rejection-sensitive individuals undermine their own needs for the sake of their partner through self-silencing behaviours (Harper, Dickson \& Welsh, 2006).

\section{Oxytocin and Crystalizing of Responses}

A number of studies have indicated that gene polymorphisms may be linked to various psychological conditions, such as brain-derived neurotrophic factor (BDNF) Val66Met and depression (Caldwell et al., 2013; Gatt et al., 2009; Oman, Okur, Eker, Eker, Gönül \& Akarsu, 2010). In this regard, a polymorphism of OXTR, specifically rs53576, has been linked to unipolar depression (Saphire-Bernstein, Way, Kim, Sherman \& Taylor, 2011; McQuaid et al., 
2013), and maladaptive coping in response to negative social interactions (McInnis et al., 2015).

Consistent with such findings, in the current study, the relationship between interpersonal trauma and rejection sensitivity was stronger for the AA genotype, compared to G carriers. Generally, the A allele is associated with poorer psychosocial functioning (Krueger et al., 2012; McQuaid et al., 2015; Rodrigues et al., 2009), and poorer mental health outcomes (Lucht et al., 2009). Furthermore, A carriers displayed greater maladaptive coping in response to negative social interaction (unsupport; McInnis et al., 2015), lower self-esteem (Saphire-Berstein et al., 2011), and poorer adaptive responses to stressors in a mice devoid of oxytocin receptors (Chini, Leonzino, Braida \& Sala, 2014). As such, the combinations of having both risk alleles (AA) and early life stressor experiences might have additive or synergistic links that favor heightened sensitivity to rejection. Indeed, the AA genotype has also been associated with Borderline Personality features (characterized by interpersonal deficits, including rejection sensitivity) among individuals raised with depressed mothers (Hammen et al., 2015), although it was suggested that this might be specific to girls (Cicchetti et al., 2014). Furthermore, although individuals with the A allele are believed to be less socially sensitive compared to their GG counterpart, they may develop a disposition that is sensitive to specific social cues (e.g. rejection). Indeed, both high rejection-sensitive A carriers and low rejection-sensitive GG carriers both had similar cortisol responses following social rejection (Auer et al., 2015). Inconsistencies that have been reported concerning gene-environment interactions involving the rs53576 SNP on the OXTR gene makes it clear that further research is needed to tease apart phenotypic variations among genotypes. Mounting research on this OXTR gene's involvement in response to positive versus negative cues or experiences (i.e., differential susceptibility hypothesis), has received increasing support (McQuaid et al., 2013, 2015; 
Smearman, Winiarski, Brennan, Najman \& Johnson, 2015). According to this view, a certain OXTR allele might be advantageous under favorable conditions, but deleterious under poor environmental conditions (e.g. early life trauma; McQuaid et al., 2013). In this respect, the confluence of negative conditions and having the mutation on both alleles (AA) might be accompanied by greater responsiveness to rejection. As such, although carriers of the $\mathrm{G}$ allele are more sensitive to the context factors of their environment and display greater variability in behavioural responses, the culmination of adverse childhood experiences and lack of adaptive prosocial behaviours might crystalize earlier in development among those with the AA genotype, thereby contributing to poorer mental health outcomes.

\section{Social Support Buffers Rejection Sensitivity}

The current study supports the buffering role of social support in relation to rejection sensitivity and depressive symptoms, including suicide ideation. Specifically, individuals with higher perceived social support had generally lower depressive symptoms in relation to rejection sensitivity than individuals with lower perceived social support. This is consistent with earlier reports indicating that perceived parental support buffers the relationship between rejection sensitivity and depressive symptoms (McDonald et al., 2010), and was particularly pronounced in the relation between rejection sensitivity and suicide ideation. Individuals scoring high and low on rejection sensitivity did not differ on suicide ideation if they perceived high levels of social support. It is conceivable that social support buffers the impact of social rejection by altering negative self-perceptions characteristic of rejection-sensitive individuals who often devalue their self-worth and self-esteem in response to rejection (Ayduk et al., 2000; Slavich, O’Donovan, Epel \& Kemeny, 2010). As such, social resources might provide adaptive coping 
that help alter how such rejection is appraised. In response to social evaluation stressors, the mere presence of a friend buffered psychological distress (Heinrichs et al., 2003). In this regard, social support might act in several ways to buffer effectively against distress caused by rejection. Specifically, social support could (1) help reappraise rejection as benign (especially in ambiguous situations), (2) provide a sense of belongingness, or (3) distract an individual from an ongoing stressor (Matheson \& Anisman, 2003).

The influence of such variables has been shown in social contexts. By example, individuals ostracized in an experimental setting, but accompanied by a friend, reported less distress than if accompanied by a stranger. However, this was only found among individuals with high self-esteem (Teng \& Chen, 2012). Social support can be effective in altering how social stressors, including rejection, are appraised, or can compensate by affirming a sense of belonging to another group. In situations in which a person perceives rejection, support might alter interpretations of rejection as benign. However, low provisions of support might leave rejectionsensitive individuals at a loss, especially in response to rejection-related distress, which might further perpetuate depressive or even suicidal thoughts (Ayduk, Downey \& Kim, 2001). Consistent with these views, in the present study perceived social support interacted with rejection sensitivity in relation to depressive symptoms, including suicide ideation. The combination of low provisions of support and high sensitivity to rejection was detrimental (e.g. greater depressive score), particularly in respect to suicide ideation. However, the knife might cut particularly deep if rejection sensitive individuals seeking support meet with negative responses. 


\section{Unsupportive Social Interactions and Rejection Sensitivity}

Unsupportive relationships can mean more than simply lack of social support. Specifically, unsupportive relations can refer to not receiving support when it was sought, or inadequate or inappropriate responses from friends or family to stressors being experienced by an individual (Ingram et al., 1999; Ingram, Betz, Mindes, Schmitt \& Smith, 2001; McInnis, McQuaid, Matheson \& Anisman, 2015). The current study demonstrated that the combination of rejection sensitivity and unsupportive social interactions were associated with greater depressive scores and suicide ideation than among individuals who had experienced few negative interactions. The impact of unsupportive relations has not been widely addressed, however, it was shown to be a strong predictor of poor mental health outcomes (Mindes, Ingram, Kliewer \& James, 2003; Talebi, Matheson \& Anisman, 2016). Indeed, greater reports of unsupportive social interactions by peers were a strong predictor of depressive symptoms. A lower threshold for perceiving rejection and experiencing unsupportive social interactions might have that much more deleterious outcomes. This may be especially pertinent, as unsupportive interactions can easily be perceived as rejection. Indeed, when support seeking is met with unhelpful (e.g. bumbling, minimizing) or negative responses (e.g. blaming, distancing), it is not surprising such responses are more harmful than simply a lack of social support (Ingram et al., 1999). As such, it might create double-trouble regarding depressive symptoms among individuals who are dispositionally sensitive to rejection experienced interpersonal trauma and subsequent unsupportive social interactions. If nothing else, unsupportive responses among those who experienced interpersonal trauma might reaffirm negatively held beliefs that one is worthless or unlikeable. 


\section{Limitations}

There are several limitations regarding the present findings. First, participants comprised a homogenous sample of Caucasian university students, which is not representative of the general population, and therefore generalizability cannot be inferred. Considering that only a Caucasian sample was analyzed, cultural and ethnic variations of the rs53576 SNP on the OXTR gene might also be considered. This would be possible with a larger sample, as it would have allowed for more detailed analyses that might have been important. Indeed, while the AA genotype is less prevalent in Caucasians, the reverse is true among Asian ethnicities (Kim et al., 2010; Sapphire-Bernstein et al., 2011). Furthermore, gender differences regarding rejection subtypes of interpersonal trauma (e.g. great sexual abuse in females, and greater physical abuse among males) might have been valuable to assess; however, the limited number of male AA genotypes would have precluded any meaningful results. Further, as indicated earlier, interpersonal trauma was reported retrospectively, and therefore might have resulted in biased reporting depending on the participants' current affective state, or participants might not have been aware adverse events that happened earlier in life. Also, the trauma inventory in the current study did not measure physical and emotional neglect, despite being the most common form of maltreatment (O’Hara, Legano, Walker-Descartes, Rojas \& Laraque, 2015), and detrimental to child development (Hildyard \& Wolfe, 2002). As such, the scope of the interpersonal trauma might not have provided the full picture of adverse early life events.

\section{Conclusion}

The current study provides insight into how rejection sensitivity contributes to the relationship between interpersonal trauma and depressive symptoms, including suicide ideation. 
Moreover, this study demonstrated the possible additive or synergistic role of having the mutation present on both alleles (AA) of the OXTR SNP rs53576 coupled with interpersonal trauma, in increasing rejection sensitivity, as well as the effect of positive and negative social interactions in mental health outcomes. Although causal claims cannot be made, perceived social support buffered the effect of rejection sensitivity in relation to depressive symptoms, and more specifically, suicide ideation. Experiencing unsupportive social interactions in relation to rejection sensitivity contributed to greater depressive symptoms and suicide ideation. Importantly, this study sheds light biological and psychosocial interactions in relation to mental health outcomes. In this regard, although broadly considered less socially sensitive, individuals with the AA genotype experiencing interpersonal trauma early in life might develop a specific behavioural phenotype that is sensitive to rejection, compared to the $\mathrm{G}$ carriers. Further research into the biological underpinnings of cognitive-affective responses (e.g. rejection sensitivity) might inform individualized treatment options among those with mental health problems. 


\section{References}

Afifi, T. O., Taillieu, T., Zamorski, M. A., Turner, S., Cheung, K., \& Sareen, J. (2016).

Association of child abuse exposure with suicidal ideation, suicide plans, and suicide attempts in military personnel and the general population in Canada. JAMA psychiatry, 73(3), 229-238.

Amann, G. (1991). Social network and social support deficits in depressed patients: a result of distorted perception?. European archives of psychiatry and clinical neuroscience, 241(1), 49-56.

Alvares, G. A., Hickie, I. B., \& Guastella, A. J. (2010). Acute effects of intranasal oxytocin on subjective and behavioral responses to social rejection. Experimental and clinical psychopharmacology, 18(4), 316.

Anders, S. L., Frazier, P. A., \& Shallcross, S. L. (2012). Prevalence and effects of life event exposure among undergraduate and community college students. Journal of counseling psychology, 59(3), 449

Arnow, B. A. (2004). Relationships between childhood maltreatment, adult health and psychiatric outcomes, and medical utilization. Journal of Clinical Psychiatry, 65, 10-15.

Aspinwall, L. G., \& Taylor, S. E. (1997). A stitch in time: self-regulation and proactive coping. Psychological bulletin, 121(3), 417.

Auer, B. J., Byrd-Craven, J., Grant, D. M., \& Granger, D. A. (2015). Common oxytocin receptor gene variant interacts with rejection sensitivity to influence cortisol reactivity during negative evaluation. Hormones and behavior, 75, 64-69.

Ayduk, Ö., Gyurak, A., \& Luerssen, A. (2008). Individual differences in the rejection-aggression link in the hot sauce paradigm: The case of rejection sensitivity. Journal of experimental 
social psychology, 44(3), 775-782.

Ayduk, O., Downey, G., \& Kim, M. (2001). Rejection sensitivity and depressive symptoms in women. Personality and Social Psychology Bulletin, 27(7), 868-877.

Ayduk, O., Mendoza-Denton, R., Mischel, W., Downey, G., Peake, P. K., \& Rodriguez, M. (2000). Regulating the interpersonal self: strategic self-regulation for coping with rejection sensitivity. Journal of personality and social psychology, 79(5), 776.

Barrera Jr, M. (2000). Social support research in community psychology. In Handbook of community psychology (pp. 215-245). Springer US.

Beck, A. T., Ward, C., \& Mendelson, M. (1961). Beck depression inventory (BDI). Arch Gen Psychiatry, 4(6), 561-571.

Belsky, J., Bakermans-Kranenburg, M. J., \& Van IJzendoorn, M. H. (2007). For better and for worse differential susceptibility to environmental influences. Current Directions in Psychological Science, 16(6), 300-304.

Belsky, J., \& Pluess, M. (2009). Beyond diathesis stress: differential susceptibility to environmental influences. Psychological bulletin, 135(6), 885.

Bernet, C. Z., \& Stein, M. B. (1999). Relationship of childhood maltreatment to the onset and course of major depression in adulthood. Depression and anxiety, 9(4), 169-174.

Blackhart, G. C., Eckel, L. A., \& Tice, D. M. (2007). Salivary cortisol in response to acute social rejection and acceptance by peers. Biological psychology, 75(3), 267-276.

Bond, L., Carlin, J. B., Thomas, L., Rubin, K., \& Patton, G. (2001). Does bullying cause emotional problems? A prospective study of young teenagers. Bmj, 323(7311), 480-484.

Bremner, J. D., Bolus, R., \& Mayer, E. A. (2007). Psychometric properties of the early trauma inventory-self report. The Journal of nervous and mental disease, 195(3), 211. 
Brendgen, M., \& Vitaro, F. (2008). Peer rejection and physical health problems in early adolescence. Journal of Developmental \& Behavioral Pediatrics, 29(3), 183-190.

Brown, R. J., Schrag, A., \& Trimble, M. R. (2005). Dissociation, childhood interpersonal trauma, and family functioning in patients with somatization disorder. American Journal of Psychiatry.

Bruffaerts, R., Demyttenaere, K., Borges, G., Haro, J. M., Chiu, W. T., Hwang, I., ... \& Andrade, L. H. (2010). Childhood adversities as risk factors for onset and persistence of suicidal behaviour. The British Journal of Psychiatry, 197(1), 20-27.

Bungert, M., Liebke, L., Thome, J., Haeussler, K., Bohus, M., \& Lis, S. (2015). Rejection sensitivity and symptom severity in patients with borderline personality disorder: effects of childhood maltreatment and self-esteem. Borderline personality disorder and emotion dysregulation, 2(1), 1 .

Burklund, L. J., Eisenberger, N. I., \& Lieberman, M. D. (2007). The face of rejection: rejection sensitivity moderates dorsal anterior cingulate activity to disapproving facial expressions. Social neuroscience, 2(3-4), 238-253.

Caldwell, W., McInnis, O. A., McQuaid, R. J., Liu, G., Stead, J. D., Anisman, H., \& Hayley, S. (2013). The role of the Val66Met polymorphism of the brain derived neurotrophic factor gene in coping strategies relevant to depressive symptoms. PloS one, 8(6), e65547.

Chen, F. S., Kumsta, R., von Dawans, B., Monakhov, M., Ebstein, R. P., \& Heinrichs, M. (2011). Common oxytocin receptor gene (OXTR) polymorphism and social support interact to reduce stress in humans. Proceedings of the National Academy of Sciences, 108(50), 19937-19942.

Chini, B., Leonzino, M., Braida, D., \& Sala, M. (2014). Learning about oxytocin: pharmacologic 
and behavioral issues. Biological psychiatry, 76(5), 360-366.

Cicchetti, D., Rogosch, F. A., Hecht, K. F., Crick, N. R., \& Hetzel, S. (2014). Moderation of maltreatment effects on childhood borderline personality symptoms by gender and oxytocin receptor and FK506 binding protein 5 genes. Development and psychopathology, 26(03), 831-849.

Clara, I. P., Cox, B. J., Enns, M. W., Murray, L. T., \& Torgrudc, L. J. (2003). Confirmatory factor analysis of the multidimensional scale of perceived social support in clinically distressed and student samples. Journal of personality assessment, 81(3), 265-270.

Cohen, S., \& Wills, T. A. (1985). Stress, social support, and the buffering hypothesis. Psychological bulletin, 98(2), 310.

Cutrona, C. E., \& Russell, D. W. (1987). The provisions of social relationships and adaptation to stress. Advances in personal relationships, 1(1), 37-67.

Cyranowski, J. M., Hofkens, T. L., Frank, E., Seltman, H., Cai, H. M., \& Amico, J. A. (2008). Evidence of dysregulated peripheral oxytocin release among depressed women. Psychosomatic Medicine, 70(9), 967.

De Carvalho Tofoli, S. M., Von Werne Baes, C., Martins, C. M. S., \& Juruena, M. (2011). Early life stress, HPA axis, and depression. Psychology \& Neuroscience, 4(2), 229.

De Marco, R. R. (2000). The epidemiology of major depression: Implications of occurrence, recurrence, and stress in a Canadian community sample. The Canadian Journal of Psychiatry/La Revue canadienne de psychiatrie.

Ditzen, B., Schaer, M., Gabriel, B., Bodenmann, G., Ehlert, U., \& Heinrichs, M. (2009). Intranasal oxytocin increases positive communication and reduces cortisol levels during couple conflict. Biological psychiatry, 65(9), 728-731. 
Dölen, G., Darvishzadeh, A., Huang, K. W., \& Malenka, R. C. (2013). Social reward requires coordinated activity of nucleus accumbens oxytocin and serotonin. Nature, 501(7466), 179-184.

Domes, G., Lischke, A., Berger, C., Grossmann, A., Hauenstein, K., Heinrichs, M., \& Herpertz, S. C. (2010). Effects of intranasal oxytocin on emotional face processing in women. Psychoneuroendocrinology, 35(1), 83-93.

Downey, G., \& Feldman, S. I. (1996). Implications of rejection sensitivity for intimate relationships. Journal of personality and social psychology, 70(6), 1327.

Downey, G., Feldman, S., \& Ayduk, O. (2000). Rejection sensitivity and male violence in romantic relationships. Personal Relationships, 7(1), 45-61.

Downey, G., Freitas, A. L., Michaelis, B., \& Khouri, H. (1998). The self-fulfilling prophecy in close relationships: rejection sensitivity and rejection by romantic partners. Journal of personality and social psychology, 75(2), 545.

Downey, G., Khouri, H., \& Feldman, S. I. (1997). Early interpersonal trauma and later adjustment: The mediational role of rejection sensitivity.

Downey, G., Mougios, V., Ayduk, O., London, B. E., \& Shoda, Y. (2004). Rejection sensitivity and the defensive motivational system: Insights from the startle response to rejection cues. Psychological Science, 15(10), 668-673.

Duncan, R. D. (1999). Maltreatment by parents and peers: The relationship between child abuse, bully victimization, and psychological distress. Child Maltreatment, 4(1), 45-55.

Dunn, E. C., McLaughlin, K. A., Slopen, N., Rosand, J., \& Smoller, J. W. (2013). Developmental timing of child maltreatment and symptoms of depression and suicidal ideation in young adulthood: results from the National Longitudinal Study of Adolescent Health. 
Depression and anxiety, 30(10), 955-964.

Edwards, V. J., Holden, G. W., Felitti, V. J., \& Anda, R. F. (2003). Relationship between multiple forms of childhood maltreatment and adult mental health in community respondents: results from the adverse childhood experiences study. American Journal of Psychiatry, 160(8), 1453-1460.

Ehnvall, A., Parker, G., Hadzi-Pavlovic, D., \& Malhi, G. (2008). Perception of rejecting and neglectful parenting in childhood relates to lifetime suicide attempts for females-but not for males. Acta Psychiatrica Scandinavica, 117(1), 50-56.

Eisenberger, N. I. (2012). The pain of social disconnection: examining the shared neural underpinnings of physical and social pain. Nature Reviews Neuroscience, 13(6), 421-434.

Elzy, M. B. (2009). Exploring the relationship between childhood sexual abuse and borderline personality features using social support as a moderating factor.

Everaert, J., Koster, E. H., \& Derakshan, N. (2012). The combined cognitive bias hypothesis in depression. Clinical psychology review, 32(5), 413-424.

Fang, A., Hoge, E. A., Heinrichs, M., \& Hofmann, S. G. (2014). Attachment style moderates the effects of oxytocin on social behaviors and cognitions during social rejection applying a research domain criteria framework to social anxiety. Clinical Psychological Science, 2167702614527948.

Fergusson, D. M., Boden, J. M., \& Horwood, L. J. (2008). Exposure to childhood sexual and physical abuse and adjustment in early adulthood. Child abuse \& neglect, 32(6), 607-619.

Finkelhor, D., Ormrod, R. K., \& Turner, H. A. (2009). The developmental epidemiology of childhood victimization. Journal of Interpersonal Violence, 24(5), 711-731.

Flanagan, J. C., Baker, N. L., McRae-Clark, A. L., Brady, K. T., \& Moran-Santa Maria, M. M. 
(2015). Effects of adverse childhood experiences on the association between intranasal oxytocin and social stress reactivity among individuals with cocaine dependence. Psychiatry research, 229(1), 94-100.

Gatt, J. M., Nemeroff, C. B., Dobson-Stone, C., Paul, R. H., Bryant, R. A., Schofield, P. R., ... \& Williams, L. M. (2009). Interactions between BDNF Val66Met polymorphism and early life stress predict brain and arousal pathways to syndromal depression and anxiety. Molecular psychiatry, 14(7), 681-695.

Gilbert, R., Widom, C. S., Browne, K., Fergusson, D., Webb, E., \& Janson, S. (2009). Burden and consequences of child maltreatment in high-income countries. The lancet, 373(9657), $68-81$.

Gimpl, G., \& Fahrenholz, F. (2001). The oxytocin receptor system: structure, function, and regulation. Physiological reviews, 81(2), 629-683.

Goodman, J., Fertuck, E., Chesin, M., Lichenstein, S., \& Stanley, B. (2014). The moderating role of rejection sensitivity in the relationship between emotional maltreatment and borderline symptoms. Personality and Individual Differences, 71, 146-150.

Gospic, K., Mohlin, E., Fransson, P., Petrovic, P., Johannesson, M., \& Ingvar, M. (2011). Limbic justice - amygdala involvement in immediate rejection in the ultimatum game. PLoS Biol, 9(5), e1001054.

Grav, S., Hellzèn, O., Romild, U., \& Stordal, E. (2012). Association between social support and depression in the general population: the HUNT study, a cross-sectional survey. Journal of clinical nursing, 21(1-2), 111-120.

Grewen, K. M., Girdler, S. S., Amico, J., \& Light, K. C. (2005). Effects of partner support on resting oxytocin, cortisol, norepinephrine, and blood pressure before and after warm 
partner contact. Psychosomatic medicine, 67(4), 531-538.

Guastella, A. J., Mitchell, P. B., \& Mathews, F. (2008). Oxytocin enhances the encoding of positive social memories in humans. Biological psychiatry, 64(3), 256-258.

Haber, M. G., Cohen, J. L., Lucas, T., \& Baltes, B. B. (2007). The relationship between selfreported received and perceived social support: A meta-analytic review. American

journal of community psychology, 39(1-2), 133-144.

Hammen, C., Bower, J. E., \& Cole, S. W. (2015). Oxytocin receptor gene variation and differential susceptibility to family environment in predicting youth borderline symptoms. Journal of personality disorders, 29(2), 177-192.

Harper, M. S., Dickson, J. W., \& Welsh, D. P. (2006). Self-silencing and rejection sensitivity in adolescent romantic relationships. Journal of Youth and Adolescence, 35(3), 435-443.

Hawkley, L. C., Thisted, R. A., Masi, C. M., \& Cacioppo, J. T. (2010). Loneliness predicts increased blood pressure: 5-year cross-lagged analyses in middle-aged and older adults. Psychology and aging, 25(1), 132.

Heinrichs, M., Baumgartner, T., Kirschbaum, C., \& Ehlert, U. (2003). Social support and oxytocin interact to suppress cortisol and subjective responses to psychosocial stress. Biological psychiatry, 54(12), 1389-1398.

Hostinar, C. E., Cicchetti, D., \& Rogosch, F. A. (2014). Oxytocin receptor gene polymorphism, perceived social support, and psychological symptoms in maltreated adolescents. Development and psychopathology, 26(02), 465-477.

Hovens, J. G. F. M., Wiersma, J. E., Giltay, E. J., Van Oppen, P., Spinhoven, P., Penninx, B. W. J. H., \& Zitman, F. G. (2010). Childhood life events and childhood trauma in adult patients with depressive, anxiety and comorbid disorders vs. controls. Acta Psychiatrica 
Scandinavica, 122(1), 66-74.

IJzerman, H., Gallucci, M., Pouw, W. T., Weißgerber, S. C., Van Doesum, N. J., \& Williams, K. D. (2012). Cold-blooded loneliness: social exclusion leads to lower skin temperatures. Acta psychologica, 140(3), 283-288.

Ingram, K. M., Betz, N. E., Mindes, E. J., Schmitt, M. M., \& Smith, N. G. (2001). Unsupportive responses from others concerning a stressful life event: Development of the Unsupportive Social Interactions Inventory. Journal of Social and Clinical Psychology, 20(2), 173-207.

Ingram, K. M., Jones, D. A., Fass, R. J., Neidig, J. L., \& Song, Y. S. (1999). Social support and unsupportive social interactions: Their association with depression among people living with HIV. AIDS care, 11(3), 313-329.

IsHak, W. W., Kahloon, M., \& Fakhry, H. (2011). Oxytocin role in enhancing well-being: A literature review. Journal of Affective Disorders, 130(1), 1-9.

Jobst, A., Sabass, L., Palagyi, A., Bauriedl-Schmidt, C., Mauer, M. C., Sarubin, N., ... \& Padberg, F. (2015). Effects of social exclusion on emotions and oxytocin and cortisol levels in patients with chronic depression. Journal of psychiatric research, 60, 170-177.

Jorden, S., Matheson, K., \& Anisman, H. (2009). Supportive and unsupportive social interactions in relation to cultural adaptation and psychological distress among Somali refugees exposed to collective or personal traumas. Journal of Cross-Cultural Psychology, 40(5), 853-874.

Katz, S. J., Conway, C. C., Hammen, C. L., Brennan, P. A., \& Najman, J. M. (2011). Childhood social withdrawal, interpersonal impairment, and young adult depression: a mediational model. Journal of abnormal child psychology, 39(8), 1227-1238.

Kendler, K. S., Hettema, J. M., Butera, F., Gardner, C. O., \& Prescott, C. A. (2003). Life event 
dimensions of loss, humiliation, entrapment, and danger in the prediction of onsets of major depression and generalized anxiety. Archives of general psychiatry, 60(8), 789-796.

Kilpatrick, D. G., Resnick, H. S., Milanak, M. E., Miller, M. W., Keyes, K. M., \& Friedman, M. J. (2013). National estimates of exposure to traumatic events and PTSD prevalence using DSM-IV and DSM-5 criteria. Journal of Traumatic Stress, 26(5), 537-547.

Kim, H. S., Sherman, D. K., Sasaki, J. Y., Xu, J., Chu, T. Q., Ryu, C., ... \& Taylor, S. E. (2010). Culture, distress, and oxytocin receptor polymorphism (OXTR) interact to influence emotional support seeking. Proceedings of the National Academy of Sciences, 107(36), $15717-15721$.

Kross, E., Berman, M. G., Mischel, W., Smith, E. E., \& Wager, T. D. (2011). Social rejection shares somatosensory representations with physical pain. Proceedings of the National Academy of Sciences, 108(15), 6270-6275.

Kross, E., Egner, T., Ochsner, K., Hirsch, J., \& Downey, G. (2007). Neural dynamics of rejection sensitivity. Journal of Cognitive Neuroscience, 19(6), 945-956.

Krueger, F., Parasuraman, R., Iyengar, V., Thornburg, M., Weel, J., Lin, M., ... \& Lipsky, R. H. (2012). Oxytocin receptor genetic variation promotes human trust behavior. Frontiers in human neuroscience, 6 .

Kumsta, R., \& Heinrichs, M. (2013). Oxytocin, stress and social behavior: neurogenetics of the human oxytocin system. Current opinion in neurobiology, 23(1), 11-16.

Lakey, B., \& Cassady, P. B. (1990). Cognitive processes in perceived social support. Journal of Personality and Social Psychology, 59(2), 337.

Langford, C. P. H., Bowsher, J., Maloney, J. P., \& Lillis, P. P. (1997). Social support: a conceptual analysis. Journal of advanced nursing, 25(1), 95-100. 
Leary, M. R., \& Baumeister, R. F. (2000). The nature and function of self-esteem: Sociometer theory.

Leary, M. R. (2015). Emotional responses to interpersonal rejection. Dialogues in clinical neuroscience, 17(4), 435.

Linnen, A. M., Ellenbogen, M. A., Cardoso, C., \& Joober, R. (2012). Intranasal oxytocin and salivary cortisol concentrations during social rejection in university students. Stress, 15(4), 393-402.

Lischke, A., Berger, C., Prehn, K., Heinrichs, M., Herpertz, S. C., \& Domes, G. (2012).

Intranasal oxytocin enhances emotion recognition from dynamic facial expressions and leaves eye-gaze unaffected. Psychoneuroendocrinology, 37(4), 475-481.

London, B., Downey, G., Bonica, C., \& Paltin, I. (2007). Social causes and consequences of rejection sensitivity. Journal of Research on Adolescence, 17(3), 481-506.

Lopez-Castroman, J., Melhem, N., Birmaher, B., Greenhill, L., Kolko, D., Stanley, B., ... \& Mann, J. J. (2013). Early childhood sexual abuse increases suicidal intent. World psychiatry, 12(2), 149-154.

Lucht, M. J., Barnow, S., Sonnenfeld, C., Rosenberger, A., Grabe, H. J., Schroeder, W., ... \& Rosskopf, D. (2009). Associations between the oxytocin receptor gene (OXTR) and affect, loneliness and intelligence in normal subjects. Progress in NeuroPsychopharmacology and Biological Psychiatry, 33(5), 860-866.

Lucht, M. J., Barnow, S., Sonnenfeld, C., Ulrich, I., Grabe, H. J., Schroeder, W., ... \& Kroemer, H. (2013). Associations between the oxytocin receptor gene (OXTR) and "mind-reading" in humans-An exploratory study. Nordic journal of psychiatry, 67(1), 15-21.

MacDonald, G., \& Leary, M. R. (2005). Why does social exclusion hurt? The relationship 
between social and physical pain. Psychological bulletin, 131(2), 202.

Marsh, A. A., Henry, H. Y., Pine, D. S., \& Blair, R. J. R. (2010). Oxytocin improves specific recognition of positive facial expressions. Psychopharmacology, 209(3), 225-232.

Matheson, K., \& Cole, B. M. (2004). Coping with a threatened group identity: Psychosocial and neuroendocrine responses. Journal of Experimental Social Psychology, 40(6), 777-786.

McDonald, K. L., Bowker, J. C., Rubin, K. H., Laursen, B., \& Duchene, M. S. (2010). Interactions between rejection sensitivity and supportive relationships in the prediction of adolescents' internalizing difficulties. Journal of Youth and Adolescence, 39(5), 563-574.

McInnis, O. A., McQuaid, R. J., Matheson, K., \& Anisman, H. (2015). The moderating role of an oxytocin receptor gene polymorphism in the relation between unsupportive social interactions and coping profiles: implications for depression. Frontiers in psychology, 6.

McQuaid, R. J., Bombay, A., McInnis, O. A., Matheson, K., \& Anisman, H. (2015). Childhood adversity, perceived discrimination, and coping strategies in relation to depressive symptoms among First Nations adults in Canada: The moderating role of unsupportive social interactions from ingroup and outgroup members. Cultural Diversity and Ethnic Minority Psychology, 21(3), 326.

McQuaid, R. J., McInnis, O. A., Matheson, K., \& Anisman, H. (2015). Distress of ostracism: oxytocin receptor gene polymorphism confers sensitivity to social exclusion. Social cognitive and affective neuroscience, nsu166.

McQuaid, R. J., McInnis, O. A., Stead, J. D., Matheson, K., \& Anisman, H. (2013). A paradoxical association of an oxytocin receptor gene polymorphism: early-life adversity and vulnerability to depression. Frontiers in neuroscience, 7.

Melrose, K. L., Brown, G. D., \& Wood, A. M. (2015). When is received social support related to 
perceived support and well-being? When it is needed. Personality and Individual Differences, 77, 97-105.

Meyer-Lindenberg, A., Domes, G., Kirsch, P., \& Heinrichs, M. (2011). Oxytocin and vasopressin in the human brain: social neuropeptides for translational medicine. Nature Reviews Neuroscience, 12(9), 524-538.

Mindes, E. J., Ingram, K. M., Kliewer, W., \& James, C. A. (2003). Longitudinal analyses of the relationship between unsupportive social interactions and psychological adjustment among women with fertility problems. Social science \& medicine, 56(10), 2165-2180.

Mohr, D. C., Classen, C., \& Barrera, M. (2004). The relationship between social support, depression and treatment for depression in people with multiple sclerosis. Psychological medicine, 34(03), 533-541.

Murray, S. L., Griffin, D. W., Rose, P., \& Bellavia, G. M. (2003). Calibrating the sociometer: the relational contingencies of self-esteem. Journal of personality and social psychology, 85(1), 63.

Nanni, V., Uher, R., \& Danese, A. (2012). Childhood maltreatment predicts unfavorable course of illness and treatment outcome in depression: a meta-analysis. American Journal of Psychiatry.

Neumann, I. D. (2008). Brain oxytocin: a key regulator of emotional and social behaviours in both females and males. Journal of neuroendocrinology, 20(6), 858-865.

Neumann, I. D., Krömer, S. A., Toschi, N., \& Ebner, K. (2000). Brain oxytocin inhibits the (re) activity of the hypothalamo-pituitary-adrenal axis in male rats: involvement of hypothalamic and limbic brain regions. Regulatory peptides, 96(1), 31-38.

Neumann, I. D., Wigger, A., Torner, L., Holsboer, F., \& Landgraf, R. (2000). Brain oxytocin 
inhibits basal and stress-induced activity of the hypothalamo-pituitary-adrenal axis in male and female rats: partial action within the paraventricular nucleus. Journal of neuroendocrinology, 12(3), 235-244.

Norman, G. J., Cacioppo, J. T., Morris, J. S., Karelina, K., Malarkey, W. B., DeVries, A. C., \& Berntson, G. G. (2011). Selective influences of oxytocin on the evaluative processing of social stimuli. Journal of Psychopharmacology, 25(10), 1313-1319.

Norman, R. E., Byambaa, M., De, R., Butchart, A., Scott, J., \& Vos, T. (2012). The long-term health consequences of child physical abuse, emotional abuse, and neglect: a systematic review and meta-analysis.

Norris, F. H. (1992). Epidemiology of trauma: frequency and impact of different potentially traumatic events on different demographic groups. Journal of consulting and clinical psychology, 60(3), 409.

O’Hara, M., Legano, L., Homel, P., Walker-Descartes, I., Rojas, M., \& Laraque, D. (2015). Children neglected: where cumulative risk theory fails. Child abuse \& neglect, 45, 1-8.

Olsson, A., Carmona, S., Downey, G., Bolger, N., \& Ochsner, K. N. (2013). Learning biases underlying individual differences in sensitivity to social rejection. Emotion, 13(4), 616.

Ozan, E., Okur, H., Eker, Ç., Eker, Ö. D., Gönül, A. S., \& Akarsu, N. (2010). The effect of depression, BDNF gene val66met polymorphism and gender on serum BDNF levels. Brain research bulletin, 81(1), 61-65.

Ozsoy, S., Esel, E., \& Kula, M. (2009). Serum oxytocin levels in patients with depression and the effects of gender and antidepressant treatment. Psychiatry research, 169(3), 249-252.

Preacher, K. J., \& Hayes, A. F. (2004). SPSS and SAS procedures for estimating indirect effects in simple mediation models. Behavior research methods, instruments, \& computers, 
36(4), 717-731.

Preacher, K. J., Rucker, D. D., \& Hayes, A. F. (2007). Addressing moderated mediation hypotheses: Theory, methods, and prescriptions. Multivariate behavioral research, 42(1), $185-227$.

Public Health Agency of Canada. Canadian Incidence Study of Reported Child Abuse and Neglect - 2008: Major Findings. Ottawa, 2010.

Ravindran, A. V., Matheson, K., Griffiths, J., Merali, Z., \& Anisman, H. (2002). Stress, coping, uplifts, and quality of life in subtypes of depression: a conceptual frame and emerging data. Journal of affective disorders, 71(1), 121-130.

Rodrigues, S. M., Saslow, L. R., Garcia, N., John, O. P., \& Keltner, D. (2009). Oxytocin receptor genetic variation relates to empathy and stress reactivity in humans. Proceedings of the National Academy of Sciences, 106(50), 21437-21441.

Romero-Canyas, R., Downey, G., Berenson, K., Ayduk, O., \& Kang, N. J. (2010). Rejection sensitivity and the rejection-hostility link in romantic relationships. Journal of personality, 78(1), 119-148.

Sanders, G., Freilicher, J., \& Lightman, S. L. (1990). Psychological stress of exposure to uncontrollable noise increases plasma oxytocin in high emotionality women. Psychoneuroendocrinology, 15(1), 47-58.

Sanfey, A. G., Rilling, J. K., Aronson, J. A., Nystrom, L. E., \& Cohen, J. D. (2003). The neural basis of economic decision-making in the ultimatum game. Science, 300(5626), 17551758. 
Saphire-Bernstein, S., Way, B. M., Kim, H. S., Sherman, D. K., \& Taylor, S. E. (2011).

Oxytocin receptor gene (OXTR) is related to psychological resources. Proceedings of the National Academy of Sciences, 108(37), 15118-15122.

Sarason, B. R., Pierce, G. R., \& Sarason, I. G. (1990). Social support: The sense of acceptance and the role of relationships.

Sijtsema, J. J., Shoulberg, E. K., \& Murray-Close, D. (2011). Physiological reactivity and different forms of aggression in girls: Moderating roles of rejection sensitivity and peer rejection. Biological Psychology, 86(3), 181-192.

Silverman, A. B., Reinherz, H. Z., \& Giaconia, R. M. (1996). The long-term sequelae of child and adolescent abuse: A longitudinal community study. Child abuse \& neglect, 20(8), 709-723.

Slavich, G. M., O’Donovan, A., Epel, E. S., \& Kemeny, M. E. (2010). Black sheep get the blues: A psychobiological model of social rejection and depression. Neuroscience $\&$ Biobehavioral Reviews, 35(1), 39-45.

Smearman, E. L., Winiarski, D. A., Brennan, P. A., Najman, J., \& Johnson, K. C. (2015). Social stress and the oxytocin receptor gene interact to predict antisocial behavior in an at-risk cohort. Development and psychopathology, 27(01), 309-318.

Sommer, K. L., \& Baumeister, R. F. (2002). Self-evaluation, persistence, and performance following implicit rejection: The role of trait self-esteem. Personality and Social Psychology Bulletin, 28(7), 926-938.

Stillman, T. F., Baumeister, R. F., Lambert, N. M., Crescioni, A. W., DeWall, C. N., \& Fincham, F. D. (2009). Alone and without purpose: Life loses meaning following social exclusion. Journal of experimental social psychology, 45(4), 686-694. 
Stroud, L. R., Foster, E., Papandonatos, G. D., Handwerger, K., Granger, D. A., Kivlighan, K. T., \& Niaura, R. (2009). Stress response and the adolescent transition: Performance versus peer rejection stressors. Development and psychopathology, 21(01), 47-68.

Talebi, M., Matheson, K., \& Anisman, H. (2016). The stigma of seeking help for mental health issues: mediating roles of support and coping and the moderating role of symptom profile. Journal of Applied Social Psychology.

Teng, F., \& Chen, Z. (2012). Does social support reduce distress caused by ostracism? It depends on the level of one's self-esteem. Journal of Experimental Social Psychology, 48(5), 1192-1195.

Thompson, S. M., Hammen, C., Starr, L. R., \& Najman, J. M. (2014). Oxytocin receptor gene polymorphism (rs53576) moderates the intergenerational transmission of depression. Psychoneuroendocrinology, 43, 11-19.

Thorsteinsson, E. B., Ryan, S. M., \& Sveinbjornsdottir, S. (2013). The mediating effects of social support and coping on the stress-depression relationship in rural and urban adolescents. Open Journal of Depression, 2(01), 1.

Tost, H., Kolachana, B., Hakimi, S., Lemaitre, H., Verchinski, B. A., Mattay, V. S., ... \& MeyerLindenberg, A. (2010). A common allele in the oxytocin receptor gene (OXTR) impacts prosocial temperament and human hypothalamic-limbic structure and function. Proceedings of the National Academy of Sciences, 107(31), 13936-13941.

Väänänen, J. M., Marttunen, M., Helminen, M., \& Kaltiala-Heino, R. (2014). Low perceived social support predicts later depression but not social phobia in middle adolescence. Health Psychology and Behavioral Medicine: an Open Access Journal, 2(1), 1023-1037. 
Vanable, P. A., Carey, M. P., Blair, D. C., \& Littlewood, R. A. (2006). Impact of HIV-related stigma on health behaviors and psychological adjustment among HIV-positive men and women. AIDS and Behavior, 10(5), 473-482.

Veening, J. G., de Jong, T., \& Barendregt, H. P. (2010). Oxytocin-messages via the cerebrospinal fluid: behavioral effects; a review. Physiology \& behavior, 101(2), 193210.

Watson, J., \& Nesdale, D. (2012). Rejection sensitivity, social withdrawal, and loneliness in young adults. Journal of Applied Social Psychology, 42(8), 1984-2005.

Wei, D., Lee, D., Cox, C. D., Karsten, C. A., Peñagarikano, O., Geschwind, D. H., ... \& Piomelli, D. (2015). Endocannabinoid signaling mediates oxytocin-driven social reward. Proceedings of the National Academy of Sciences, 112(45), 14084-14089.

Widom, C. S., DuMont, K., \& Czaja, S. J. (2007). A prospective investigation of major depressive disorder and comorbidity in abused and neglected children grown up. Archives of general psychiatry, 64(1), 49-56.

Williams, D. R., Neighbors, H. W., \& Jackson, J. S. (2003). Racial/ethnic discrimination and health- findings from community studies. American journal of public health, 93(2), 200208.

Wilson, C. L., \& Ruben, M. A. (2011). A pain in her arm: Romantic attachment orientations and the tourniquet task. Personal Relationships, 18(2), 242-265.

Witvliet, M., Brendgen, M., Van Lier, P. A., Koot, H. M., \& Vitaro, F. (2010). Early adolescent depressive symptoms: Prediction from clique isolation, loneliness, and perceived social acceptance. Journal of abnormal child psychology, 38(8), 1045-1056. 
Zadro, L., Williams, K. D., \& Richardson, R. (2004). How low can you go? Ostracism by a computer is sufficient to lower self-reported levels of belonging, control, self-esteem, and meaningful existence. Journal of Experimental Social Psychology, 40(4), 560-567.

Zimmer-Gembeck, M. J., \& Nesdale, D. (2013). Anxious and angry rejection sensitivity, social withdrawal, and retribution in high and low ambiguous situations. Journal of Personality, 81(1), 29-38. 


\section{Appendix A \\ Study Questionnaires}

\section{Background Information}

The purpose of the following set of questions is to collect demographic information about various aspects of your life. Although some of the questions may seem unrelated to the present study (e.g. weight, height, religion, etc...) these factors may be important determinants of your health and well-being.

1. Sex: Female / Male (please select one)

2. Age:

3. What is your citizenship status?

Canadian citizen

Landed immigrant Since what year?

Student visa Since what year?

Temporary visa Since what year?

Refugee

Since what year?

Country of origin

Country of origin

Country of origin

Country of origin

4. What is your first language?

If your first language is not English, how long have you been fluent in reading, writing and comprehension of the English language?

5. What is your ethnic/racial background? Please select the one that best applies to you.

Asian (e.g., Chinese, Japanese, Korean)

South Asian (e.g., East Indian, Pakistani, Punjabi, Tamil, Sri Lankan)

South East Asian (e.g., Cambodian, Indonesian, Laotian)

Arab/West Asian (e.g., Armenian, Egyptian, Iranian, Lebanese, Moroccan)

Black (e.g., African, Haitian, Jamaican, Somali)

Latin American/Hispanic

Aboriginal

White/Euro-Caucasian

Other (please specify):

6. What is your religious affiliation? Please select the one that best applies to you.

None-Atheist (e.g., belief that there is NO God)

None-Agnostic (e.g., belief that the existence of God cannot be known)

Protestant (e.g., United, Anglican, Baptist, Presbyterian, Lutheran, Pentecostal, Mennonite, "Christian”)

Catholic (e.g., Roman Catholic, Ukrainian Catholic)

Jewish

Muslim

Buddhist

Hindu

Sikh

Bahá'í

Other (please specify):

7. What is your current living arrangement? Please select the one that best applies to you.

Living alone in residence (at Carleton University)

Living alone off-campus

Living with friends in residence (at Carleton University)

Living with friends off-campus

Living with roommates in residence (at Carleton University)

Living with roommates off-campus

Living with parents

Living with spouse/significant other 
Living with spouse/significant other and young children (13 years and younger)

Living with spouse/significant other and older children (13 years and older)

Living alone with young children (13 years and younger)

Living alone with older children (13 years and older)

Other (please specify)

8. What is your sexual orientation? Please select the one that best applies to you.

Straight/Heterosexual

Lesbian

Gay

Bisexual

Transgender

Queer

Don't Know

Other (please specify)

9. What is your current relationship status? Please select the one that best applies to you.

Single, and not seeing anyone

Going out with someone

In a serious dating relationship

Have recently broken up ...

Please specify how many weeks ago you broke up

Living with an intimate other

Engaged

Married

Separated/Divorced ........

Widowed

Please specify how many months ago you separated

10. Is your current (or most recent) partner: Male

OR

Female ?

11. What level of education have you completed?

8 years or less of elementary school

some high school but no diploma

a high school diploma or equivalent

1 to 3 years of college/university (including study at a technical college or CEGEP)

an undergraduate university degree

a master's degree

a doctoral degree

a professional degree [medicine (M.D.), dentistry (D.D.S.), law, etc.]

12. Have you had or do you currently have any health related (i.e., medical) illnesses or physical conditions? Please select the one that best applies to you.

NO, I don't

YES, I did but I no longer do

YES, I do

If YES, please specify illness/condition you had/have

If YES, please specify any current treatment you are receiving

13. Do you currently have a psychological disorder/condition (e.g. depression, anxiety, etc.)?

NO, I don't

YES, I do

If YES, please specify disorder/condition

If YES, are you currently being treated for this disorder/condition?

NO, I'm not 
If YES, please specify treatment type (e.g. medications, therapy).

14. Have you ever in the past had a psychological disorder/condition (e.g. depression, anxiety, etc.) but no longer do? NO, I haven't YES, I have

If YES, please specify the disorder/condition you had

15. In your opinion, how would you describe your health?

Poor
Fair
Good
Very good
Excellent

16. Are you on any of the following medications (please check all that apply)?

Anti-inflammatories (please specify)

Anti-depressants (please specify)

Anti-anxieties (please specify)

Allergy medication (please specify)

Other prescription drugs (please specify)

17. What is your estimate of your family's gross income per year? Please select the one that best applies to you. under $\$ 15,000$

$\$ 15,000$ - \$29,999

$\$ 60,000$ - $\$ 74,999$

$\$ 30,000$ - \$44,999

$\$ 75,000-\$ 89,999$

$\$ 45,000$ - \$59,999

$\$ 90,000-\$ 104,999$

$\$ 105,000$ or more

18. What is your employment status?

Employed Part-time

Employed Full-time

Unemployed

Retired

Other: 
On this questionnaire are groups of statements. Please read the entire group of statements in each category. Then pick out ONE statement in that group which best describes the way you feel. Check off the number beside the statement you have chosen.

1.

$\begin{array}{ll}0 & \text { I do not feel sad } \\ 1 & \text { I feel sad or blue } \\ 2 a & \text { I am blue or sad all of the time and I can't snap out of it } \\ 2 b & \text { I am so sad or unhappy that it is very painful } \\ 3 & \text { I am so sad or unhappy that I can't stand it }\end{array}$

2.

$0 \quad$ I am not particularly pessimistic or discouraged about the future

1 I feel discouraged about the future

2a I feel I have nothing to look forward to

$2 \mathrm{~b}$ I feel I won't every get over my troubles

3 I feel that the future is hopeless and things cannot improve

3.

$0 \quad$ I do not feel like a failure

1 I feel I have failed more than the average person

2a I feel I have accomplished very little that is worthwhile or that means anything

$2 \mathrm{~b} \quad$ As I look back on my life, all I can see is a lot of failures

3 I feel I am a complete failure as a person

4.

$\begin{array}{ll}0 & \text { I am not particularly dissatisfied } \\ \text { 1a } & \text { I feel bored most of the time } \\ \text { 1b } & \text { I don't enjoy things the way I used to } \\ 2 & \text { I don't get satisfaction out of anything anymore } \\ 3 & \text { I am dissatisfied with everything }\end{array}$

5.

0 I don't feel particularly guilty

1 I feel bad or unworthy a good part of the time

2a I feel quite guilty

2 b I feel bad or unworthy practically of the time now

3 I feel as though I am very bad or worthless

6.

0 I don't feel I am being punished

1 I have a feeling that something bad may happen to me

2 I feel I am being punished or will be punished

3a I feel I deserve to be punished

$3 \mathrm{~b}$ I want to be punished

7.

$0 \quad$ I don't feel disappointed in myself

1a I am disappointed in myself

1b I don't like myself

2 I am disgusted with myself

3 I hate myself

8.

0 I do not feel I am any worse than anybody else

1 I am very critical of myself for my weaknesses or mistakes

2a I blame myself for everything that goes wrong

2b I feel I have many bad faults 
9.

\begin{tabular}{l}
0 \\
1 \\
$2 \mathrm{a}$ \\
$2 \mathrm{~b}$ \\
$2 \mathrm{c}$ \\
\hline 3
\end{tabular}

10. 0 I don't cry anymore than usual

1 I cry more now than I used to

2 I cry all the time now. I can't stop it

3 I used to be able to cry but now I can't cry at all even though I want to

11.

- I am no more irritable than usual

1 I am more irritable than usual

2 I am much more irritable than usual

3 I am irritable all the time

12. 0

13. 0

\section{1}

2

3

I have not lost interest in other people

I am less interested in other people than I used to be

I have lost most of my interest in other people and I have little feeling for them

I have lost all my interest in other people and don't care about them at all

I make decisions about as well as ever

I am less sure of myself now and try to put off making decisions

I can't make decisions anymore without help

I can't make decisions at all anymore

14.

0 I don't feel I look any worse than I used to

1 I am worried that I am looking old or unattractive

2 I feel that there are permanent changes in my appearance and they make me look unattractive

3 I feel that I am ugly or repulsive looking

15.

0 I can work about as well as before

1a It takes extra effort to get started at doing something

1b I don't work as well as I used to

2 I have to push myself very hard to do anything

3 I can't do any work at all

16.

$0 \quad$ I can sleep as well as usual

1 I wake up more tired in the morning than I used to

2 I wake up 1-2 hours earlier than usual and find it hard to get back to sleep

3 I wake up early every day and can't get more than 5 hours sleep

17.

I don't get any more tired than usual

I get tired more easily than I used to

I get tired from doing anything

I get too tired to do anything

18a.

0 My appetite is no worse than usual

1 My appetite is not as good as it used to be

2 My appetite is much worse now

3 I have no appetite at all any more

$18 b$.

0 I am not eating more than usual

1 I am eating a little more than usual 
2 I am eating somewhat more than usual

3 I am eating a lot more than usual

18c.__ 0 I have had no change in food preferences lately

1 I have been craving more carbohydrates (starches or sweets lately)

2 I have had irresistible craving for sweets and starches lately

19a.___ 0 I haven't lost much weight, if any, lately

1 I have lost more than 5 pounds

2 I have lost more than 10 pounds

3 I have lost more than 15 pounds

19b.___ 0 I have not gained any weight lately

1 I have gained more than 5 pounds

2 I have gained more than 10 pounds

3 I have gained more than 15 pounds

20.

0 I am no more concerned about my health than usual

1 I am concerned about aches and pains or upset stomach or constipation or other unpleasant feelings in my body

2 I am so concerned with how I feel or what I feel that it's hard to think of much else

3 I am completely absorbed in what I feel

21.

0 I have not noticed any recent change in my interest in sex

1 I am less interested in sex than I used to be

2 I am much less interested in sex now

3 I have lost interest in sex completely

22. _ 0 I have not had any increase in nightly sleep length lately

1 I have had at least 1-hour increase in sleep length

2 I have had at least 2-hour increase in sleep length

3 I have had at least 3-hour increase in sleep length

My average nightly sleep length in the past week is:

hours

23. 0 I am not feeling more fatigued than usual

1 I feel more fatigued than usual lately, but it does not interfere with my daily functioning

2 I feel more fatigued than usual lately, and it interferes somewhat with my daily functioning

3 I feel more fatigued than usual lately, and it significantly interferes with my daily functioning

24. 0 I have not had any mood swings or slumps lately

1 I have had some mood swings or slumps lately but very minor

2 I have had more mood swings or slumps than usual

3 I have had severe mood swings or slumps lately 
Instructions: In answering the following questions, think about your current relationships with friends, family members, co-workers, community members, and so on. Please indicate to what extent each statement describes your current relationship with other people. Use the following sale to indicate your opinion.

So, for example, if you feel a statement is very true of your current relationships, you would respond with a 4 (strongly agree). If you feel a statement clearly does not describe your relationships, you would respond with a 1 (strongly disagree).

\begin{tabular}{|c|c|c|c|c|}
\hline & $\begin{array}{l}\text { Strongly } \\
\text { Disagree }\end{array}$ & Disagree & Agree & $\begin{array}{l}\text { Strongly } \\
\text { Agree }\end{array}$ \\
\hline 1. There are people I can depend on to help me if I really need it. & 1 & 2 & 3 & 4 \\
\hline 2. I feel that I do not have close personal relationships with other people. & 1 & 2 & 3 & 4 \\
\hline 3. There is no one I can turn to for guidance in times of stress. & 1 & 2 & 3 & 4 \\
\hline 4. There are people who depend on me for help. & 1 & 2 & 3 & 4 \\
\hline 5. There are people who enjoy the same social activities I do. & 1 & 2 & 3 & 4 \\
\hline 6. Other people do not view me as competent. & 1 & 2 & 3 & 4 \\
\hline 7. I feel personally responsible for the well-being of another person. & 1 & 2 & 3 & 4 \\
\hline 8. I feel part of a group of people who share my attitudes and beliefs. & 1 & 2 & 3 & 4 \\
\hline 9. I do not think of other people respect my skills and abilities. & 1 & 2 & 3 & 4 \\
\hline 10. If something went wrong, no one would come to my assistance. & 1 & 2 & 3 & 4 \\
\hline $\begin{array}{l}\text { 11. I have close relationships that provide me with a sense of emotional security } \\
\text { and well-being. }\end{array}$ & 1 & 2 & 3 & 4 \\
\hline 12. There is someone I could talk to about important decisions in my life. & 1 & 2 & 3 & 4 \\
\hline 13. I have relationships where my competence and skill are recognized. & 1 & 2 & 3 & 4 \\
\hline 14. There is no one who shares my interests and concerns. & 1 & 2 & 3 & 4 \\
\hline 15. There is no one who really relies on me for their well-being. & 1 & 2 & 3 & 4 \\
\hline $\begin{array}{l}\text { 16. There is a trustworthy person I could turn to for advice if I were having } \\
\text { problems. }\end{array}$ & 1 & 2 & 3 & 4 \\
\hline 17. I feel a strong emotional bond with at least one other person. & 1 & 2 & 3 & 4 \\
\hline 18. There is no one I can depend on for aid if I really need it. & 1 & 2 & 3 & 4 \\
\hline 19. There is no one I feel comfortable talking about problems with. & 1 & 2 & 3 & 4 \\
\hline
\end{tabular}




\begin{tabular}{l|c|c|c|} 
20. There are people who admire my talents and abilities & 1 & 2 & 3 \\
21. I lack a feeling of intimacy with another person. & 1 & 2 & 3 \\
22. There is no one who lies to do things I do. & 1 & 2 & 3 \\
23. There are people who I can count on in an emergency. & 1 & 2 & 3 \\
24. No one needs me to care for them. & 1 & 2 \\
\hline
\end{tabular}


Please think about times you've turned to your friends for support in regards to a situation that was bothering you (i.e. frustrations or disappointments with friends, family, school, health, work or anything else that is important to you). For each of the statements below, please circle the number that indicates how frequently your friends responded in this way when you went to them for support.

\section{None}

A Lot

1. Would not seem to want to hear about it.

0

2. Would refuse to take me seriously.

0

3. Would change the subject before I wanted to.

0

0

1

2

3

4

4. Would refuse to provide the type of help or support I was asking for.

0

1

2

34

5. When I was talking about it, the person wouldn't give me enough time, or would make me feel like I should hurry.

0

6. Would discourage me from expressing feelings such as anger, hurt or sadness.

7. Would not seem to know what to say, or would seem afraid of saying or doing the "wrong" thing.

0

1

$\begin{array}{lllll}0 & 1 & 2 & 3 & 4\end{array}$

8. Would seem to be telling me what he or she thought I wanted to hear.

0
9. From voice tone, expression, or body language, I would get the feeling he or she was uncomfortable talking about it.

0

10. Would try to cheer me up when I was not ready to.

11. Would respond with uninvited physical touching (e.g., hugging).

0

1

2

34

12. Would do things for me that I would want to do and could do myself.

0

1

2


21. Would tell me that I had gotten myself into the situation in the first place, and now must deal with the consequences.

22. Would blame me, or try to make me feel responsible for the event.

23. Would make "I told you so" or similar comments.
24. Would seem to be disappointed in me.

\section{0}

0

0
1

2

3

4

1

$\begin{array}{llll}1 & 2 & 3 & 4\end{array}$

\begin{tabular}{llllll}
0 & 1 & 2 & 3 & 4 \\
\hline
\end{tabular}


Each of the items below describes things college students sometimes ask of other people. Please imagine that you are in each situation. You will be asked to answer the following questions:

1) How concerned or anxious would you be about how the other person would respond?

2) How do you think the other person would be likely to respond?

\section{You ask someone in class if you can borrow his/her notes.}

\begin{tabular}{|c|c|c|c|c|c|c|}
\hline $\begin{array}{l}\text { How concerned or anxious would you be over whether or } \\
\text { not the person would want to lend you his/her notes? }\end{array}$ & $\begin{array}{l}\text { Very } \\
\text { Unconce }\end{array}$ & & & & & $\begin{array}{r}\text { Very } \\
\text { Concerned }\end{array}$ \\
\hline & 1 & 2 & 3 & 4 & 5 & 6 \\
\hline $\begin{array}{l}\text { I would expect that the person would willingly give me } \\
\text { his/her notes. }\end{array}$ & $\begin{array}{l}\text { Very } \\
\text { Unlikely }\end{array}$ & & & & & $\begin{array}{l}\text { Very } \\
\text { Likely }\end{array}$ \\
\hline & 1 & 2 & 3 & 4 & 5 & 6 \\
\hline
\end{tabular}

2. You ask your boyfriend/girlfriend to move in with you.

\begin{tabular}{|c|c|c|c|c|c|c|}
\hline \multirow[t]{2}{*}{$\begin{array}{l}\text { How concerned or anxious would you be over whether or } \\
\text { not the person would want to move in with you? }\end{array}$} & \multicolumn{4}{|c|}{$\begin{array}{l}\text { Very } \\
\text { Unconcerned }\end{array}$} & \multirow{2}{*}{\multicolumn{2}{|c|}{$\begin{array}{cc} & \begin{array}{c}\text { Very } \\
\text { Concerned }\end{array} \\
5 & 6\end{array}$}} \\
\hline & 1 & 2 & 3 & 4 & & \\
\hline I would expect that he/she would want to move in with me. & $\begin{array}{l}\text { Very } \\
\text { Unlikely }\end{array}$ & & & & & $\begin{array}{l}\text { Very } \\
\text { Likely }\end{array}$ \\
\hline
\end{tabular}

\section{You ask your parents for help in deciding what programs to apply to.}

\begin{tabular}{|c|c|c|c|c|c|c|}
\hline $\begin{array}{l}\text { How concerned or anxious would you be over whether or } \\
\text { not your parents would want to help you? }\end{array}$ & $\begin{array}{l}\text { Very } \\
\text { Unconce }\end{array}$ & & & & & $\begin{array}{r}\text { Very } \\
\text { Concerned }\end{array}$ \\
\hline & 1 & 2 & 3 & 4 & 5 & 6 \\
\hline I would expect that they would want to help me. & $\begin{array}{l}\text { Very } \\
\text { Unlikely }\end{array}$ & & & & & $\begin{array}{l}\text { Very } \\
\text { Likely }\end{array}$ \\
\hline
\end{tabular}

\section{You ask someone you don't know well out on a date.}

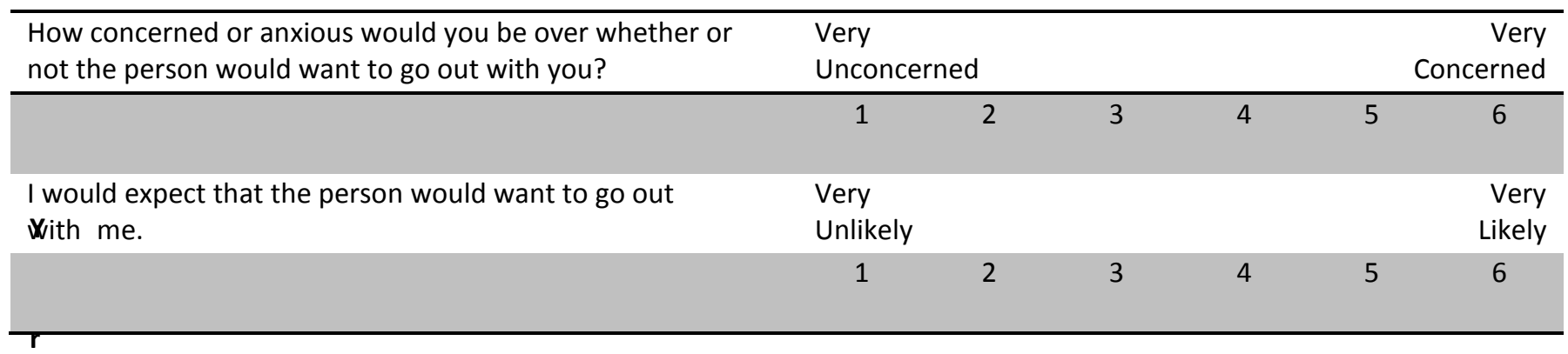

5. Your boyfriend/girlfriend has plans to go out with friends tonight, but you really want to spend the evening with him/her, and you tell him/her so. 


\begin{tabular}{|c|c|c|c|c|c|c|}
\hline \multirow[t]{2}{*}{$\begin{array}{l}\text { How concerned or anxious would you be over whether or } \\
\text { not your boyfriend/girlfriend would decide to stay in? }\end{array}$} & \multicolumn{4}{|c|}{$\begin{array}{l}\text { Very } \\
\text { Unconcerned }\end{array}$} & \multirow{2}{*}{\multicolumn{2}{|c|}{$\begin{array}{r}\text { Very } \\
\text { Concerned } \\
5 \quad 6\end{array}$}} \\
\hline & 1 & 2 & 3 & 4 & & \\
\hline $\begin{array}{l}\text { I would expect that the person would willingly choose to } \\
\text { stay in. }\end{array}$ & $\begin{array}{l}\text { Very } \\
\text { Unlikely }\end{array}$ & & & & & $\begin{array}{l}\text { Very } \\
\text { Likely }\end{array}$ \\
\hline & 1 & 2 & 3 & 4 & 5 & 6 \\
\hline
\end{tabular}

6. You ask your parents for extra money to cover living expenses.

\begin{tabular}{|c|c|c|c|c|c|c|}
\hline $\begin{array}{l}\text { How concerned or anxious would you be over whether or } \\
\text { not your parents would help you out? }\end{array}$ & $\begin{array}{l}\text { Very } \\
\text { Unconce }\end{array}$ & & & & & $\begin{array}{r}\text { Very } \\
\text { Concerned }\end{array}$ \\
\hline & 1 & 2 & 3 & 4 & 5 & 6 \\
\hline $\begin{array}{l}\text { I would expect that my parents would not mind helping me } \\
\text { out. }\end{array}$ & $\begin{array}{l}\text { Very } \\
\text { Unlikely }\end{array}$ & & & & & $\begin{array}{l}\text { Very } \\
\text { Likely }\end{array}$ \\
\hline
\end{tabular}

7. After class, you tell your professor that you have been having some trouble with a section of the course and ask if he/she can give you some extra help.

\begin{tabular}{|c|c|c|c|c|c|c|}
\hline $\begin{array}{l}\text { How concerned or anxious would you be over whether or } \\
\text { not your professor would want to help you out? }\end{array}$ & $\begin{array}{l}\text { Very } \\
\text { Unconce }\end{array}$ & & & & & $\begin{array}{r}\text { Very } \\
\text { Concerned }\end{array}$ \\
\hline & 1 & 2 & 3 & 4 & 5 & 6 \\
\hline $\begin{array}{l}\text { I would expect that my professor would want to help me } \\
\text { out. }\end{array}$ & $\begin{array}{l}\text { Very } \\
\text { Unlikely }\end{array}$ & & & & & $\begin{array}{l}\text { Very } \\
\text { Likely }\end{array}$ \\
\hline
\end{tabular}

8. You approach a close friend to talk after doing or saying something that seriously upset him/her.

\begin{tabular}{|c|c|c|c|c|c|c|}
\hline \multirow[t]{2}{*}{$\begin{array}{l}\text { How concerned or anxious would you be over whether or } \\
\text { not your friend would want to talk with you? }\end{array}$} & \multicolumn{4}{|c|}{$\begin{array}{l}\text { Very } \\
\text { Unconcerned }\end{array}$} & \multirow{2}{*}{\multicolumn{2}{|c|}{$\begin{array}{c}\begin{array}{c}\text { Very } \\
\text { Concerned }\end{array} \\
6\end{array}$}} \\
\hline & 1 & 2 & 3 & 4 & & \\
\hline $\begin{array}{l}\text { I would expect that he/she would want to talk with me to try } \\
\text { to work things out. }\end{array}$ & $\begin{array}{l}\text { Very } \\
\text { Unlikely }\end{array}$ & & & & & $\begin{array}{l}\text { Very } \\
\text { Likely }\end{array}$ \\
\hline & 1 & 2 & 3 & 4 & 5 & 6 \\
\hline
\end{tabular}

\section{You ask someone in one of your classes to coffee.}

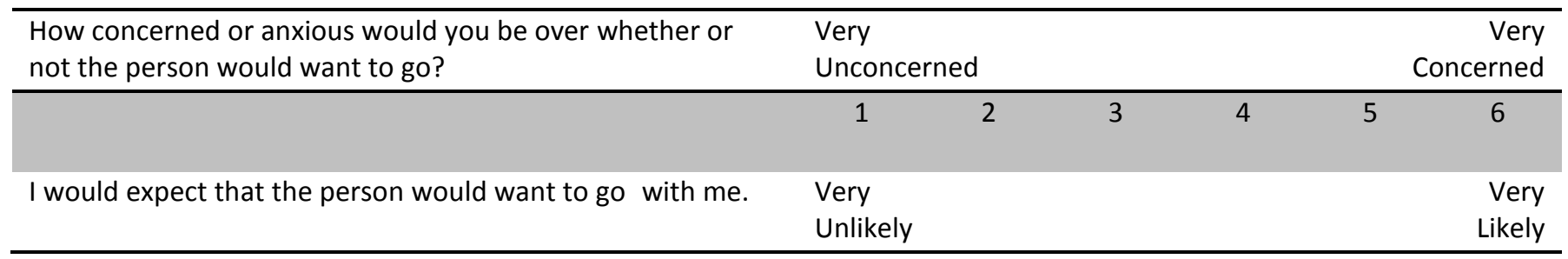




\begin{tabular}{llllllllll}
\hline & 1 & 2 & 3 & 5 & 5 & & & \\
\hline
\end{tabular}

10. After graduation, you can't find a job and ask your parents if you can live at home for a while.

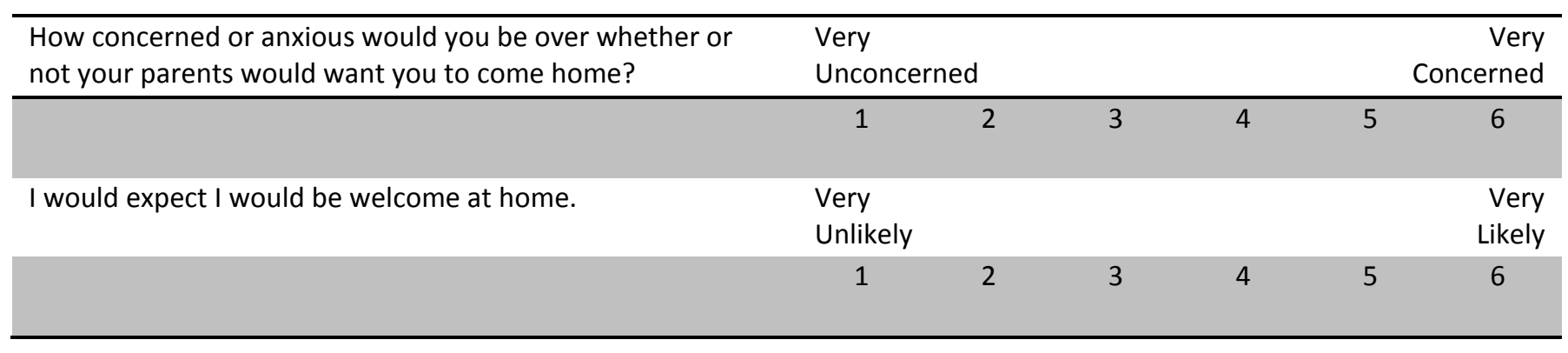

11. You ask your friend to go on a vacation with you over Spring Break.

\begin{tabular}{|c|c|c|c|c|c|c|}
\hline \multirow[t]{2}{*}{$\begin{array}{l}\text { How concerned or anxious would you be over whether or } \\
\text { not your friend would want to go with you? }\end{array}$} & \multicolumn{4}{|c|}{$\begin{array}{l}\text { Very } \\
\text { Unconcerned }\end{array}$} & \multirow{2}{*}{\multicolumn{2}{|c|}{$\begin{array}{r}\begin{array}{r}\text { Very } \\
\text { Concerned }\end{array} \\
6\end{array}$}} \\
\hline & 1 & 2 & 3 & 4 & & \\
\hline I would expect that he/she would want to go with me. & $\begin{array}{l}\text { Very } \\
\text { Unlikely }\end{array}$ & & & & & $\begin{array}{l}\text { Very } \\
\text { Likely }\end{array}$ \\
\hline
\end{tabular}

12. You call your boyfriend/girlfriend after a bitter argument and tell him/her you want to see him/her.

\begin{tabular}{|c|c|c|c|c|c|c|}
\hline \multirow[t]{2}{*}{$\begin{array}{l}\text { How concerned or anxious would you be over whether or } \\
\text { not your boyfriend/girlfriend would want to see you? }\end{array}$} & \multicolumn{4}{|c|}{$\begin{array}{l}\text { Very } \\
\text { Unconcerned }\end{array}$} & \multirow{2}{*}{\multicolumn{2}{|c|}{$\begin{array}{cc} & \begin{array}{r}\text { Very } \\
\text { Concerned }\end{array} \\
5 & 6\end{array}$}} \\
\hline & 1 & 2 & 3 & 4 & & \\
\hline I would expect that he/she would want to see me. & $\begin{array}{l}\text { Very } \\
\text { Unlikely }\end{array}$ & & & & & $\begin{array}{l}\text { Very } \\
\text { Likely }\end{array}$ \\
\hline
\end{tabular}

13. You ask a friend if you can borrow something of his/hers.

\begin{tabular}{|c|c|c|c|c|c|c|}
\hline $\begin{array}{l}\text { How concerned or anxious would you be over whether or } \\
\text { not your friend would want to loan it to you? }\end{array}$ & $\begin{array}{l}\text { Very } \\
\text { Unconce }\end{array}$ & & & & & $\begin{array}{r}\text { Very } \\
\text { Concerned }\end{array}$ \\
\hline & 1 & 2 & 3 & 4 & 5 & 6 \\
\hline I would expect that he/she would willingly loan me it. & $\begin{array}{l}\text { Very } \\
\text { Unlikely }\end{array}$ & & & & & $\begin{array}{l}\text { Very } \\
\text { Likely }\end{array}$ \\
\hline
\end{tabular}

\section{You ask your parents to come to an occasion important to you.}

\begin{tabular}{lcccc}
\hline $\begin{array}{l}\text { How concerned or anxious would you be over whether or } \\
\text { not your parents would want to come? }\end{array}$ & $\begin{array}{l}\text { Very } \\
\text { Unconcerned }\end{array}$ & $\begin{array}{l}\text { Very } \\
\text { Concerned }\end{array}$ \\
\hline & 1 & 2 & 3 & 4 \\
\hline
\end{tabular}




\begin{tabular}{|c|c|c|c|c|c|c|}
\hline I would expect that my parents would want to come. & $\begin{array}{l}\text { Very } \\
\text { Unlikely }\end{array}$ & & & & & $\begin{array}{l}\text { Very } \\
\text { Likely }\end{array}$ \\
\hline & 1 & 2 & 3 & 4 & 5 & 6 \\
\hline
\end{tabular}

\section{You ask a friend to do you a big favor.}

\begin{tabular}{|c|c|c|c|c|c|c|}
\hline \multirow{2}{*}{$\begin{array}{l}\text { How concerned or anxious would you be over whether or } \\
\text { not your friend would do this favor? }\end{array}$} & \multicolumn{4}{|c|}{$\begin{array}{l}\text { Very } \\
\text { Unconcerned }\end{array}$} & \multirow{2}{*}{\multicolumn{2}{|c|}{$\begin{array}{r}\text { Very } \\
\text { Concerned } \\
6\end{array}$}} \\
\hline & 1 & 2 & 3 & 4 & & \\
\hline $\begin{array}{l}\text { I would expect that he/she would willingly do this favor for } \\
\text { me. }\end{array}$ & $\begin{array}{l}\text { Very } \\
\text { Unlikely }\end{array}$ & & & & & $\begin{array}{l}\text { Very } \\
\text { Likely }\end{array}$ \\
\hline & 1 & 2 & 3 & 4 & 5 & 6 \\
\hline
\end{tabular}

16. You ask your boyfriend/girlfriend if he/she really loves you.

\begin{tabular}{|c|c|c|c|c|c|c|}
\hline $\begin{array}{l}\text { How concerned or anxious would you be over whether or } \\
\text { not your boyfriend/girlfriend would say yes? }\end{array}$ & $\begin{array}{l}\text { Very } \\
\text { Unconce }\end{array}$ & & & & & $\begin{array}{r}\text { Very } \\
\text { Concerned }\end{array}$ \\
\hline & 1 & 2 & 3 & 4 & 5 & 6 \\
\hline I would expect that he/she would answer yes sincerely. & $\begin{array}{l}\text { Very } \\
\text { Unlikely }\end{array}$ & & & & & $\begin{array}{l}\text { Very } \\
\text { Likely }\end{array}$ \\
\hline
\end{tabular}

\section{You go to a party and notice someone on the other side of the room and then you ask them to dance.}

\begin{tabular}{|c|c|c|c|c|c|c|}
\hline $\begin{array}{l}\text { How concerned or anxious would you be over whether or } \\
\text { not the person would want to dance with you? }\end{array}$ & $\begin{array}{l}\text { Very } \\
\text { Unconce }\end{array}$ & & & & & $\begin{array}{r}\text { Very } \\
\text { Concerned }\end{array}$ \\
\hline & 1 & 2 & 3 & 4 & 5 & 6 \\
\hline I would expect that he/she would want to dance with me. & $\begin{array}{l}\text { Very } \\
\text { Unlikely }\end{array}$ & & & & & $\begin{array}{l}\text { Very } \\
\text { Likely }\end{array}$ \\
\hline & 1 & 2 & 3 & 4 & 5 & 6 \\
\hline
\end{tabular}

18. You ask your boyfriend/girlfriend to come home to meet your parents.

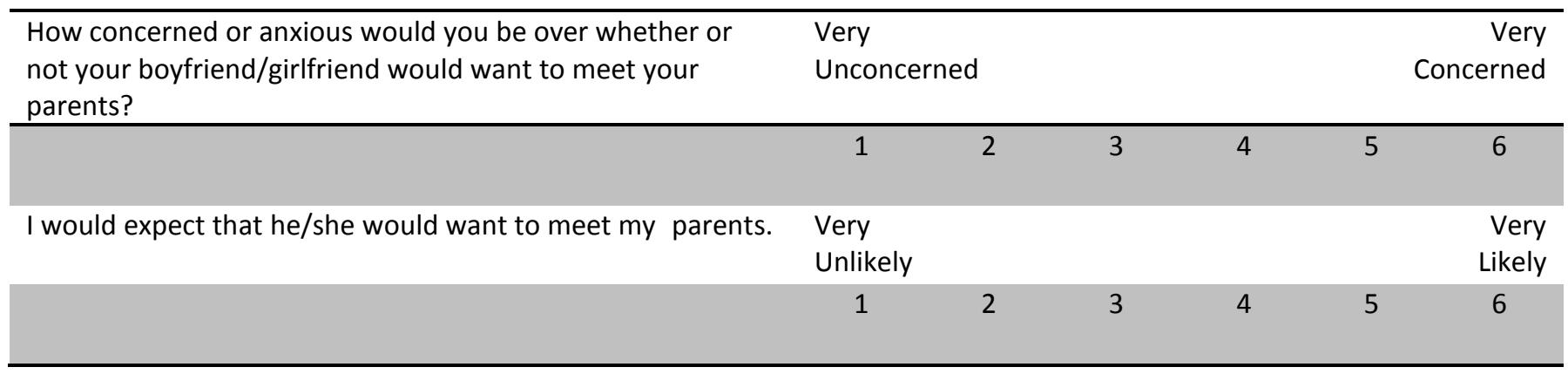


ELTI

Most people have experienced a traumatic event at some point in their life. For this survey, we are interested in the types of traumatic events that you may have experienced, and how old you were when you experienced it. For each question, please indicate how many times you have experienced the event (if at all), and at what age range, by circling the appropriate number.

Part 1. General Traumas

1. Were you ever exposed to a life-threatening natural disaster?

\begin{tabular}{|c|c|c|c|c|c|c|}
\hline Age 0 to 5 & $\begin{array}{l}0 \\
\text { Never }\end{array}$ & $\begin{array}{l}1 \\
\text { Once }\end{array}$ & $\begin{array}{l}2 \\
2-3 \text { times }\end{array}$ & $\begin{array}{l}3 \\
4-5 \text { times }\end{array}$ & $\begin{array}{l}4 \\
6-10 \text { times }\end{array}$ & $\begin{array}{l}5 \\
\text { More than } 10 \text { times }\end{array}$ \\
\hline Age 6 to 12 & $\begin{array}{l}0 \\
\text { Never }\end{array}$ & $\begin{array}{l}1 \\
\text { Once }\end{array}$ & $\begin{array}{l}2 \\
2-3 \text { times }\end{array}$ & $\begin{array}{l}3 \\
4-5 \text { times }\end{array}$ & $\begin{array}{l}4 \\
6-10 \text { times }\end{array}$ & $\begin{array}{l}5 \\
\text { More than } 10 \text { times }\end{array}$ \\
\hline Age 13 to 18 & $\begin{array}{l}0 \\
\text { Never }\end{array}$ & $\begin{array}{l}1 \\
\text { Once }\end{array}$ & $\begin{array}{l}2 \\
2-3 \text { times }\end{array}$ & $\begin{array}{l}3 \\
4-5 \text { times }\end{array}$ & $\begin{array}{l}4 \\
6-10 \text { times }\end{array}$ & $\begin{array}{l}5 \\
\text { More than } 10 \text { times }\end{array}$ \\
\hline \multicolumn{7}{|c|}{ 2. Were you involved in a serious accident? } \\
\hline Age 0 to 5 & $\begin{array}{l}0 \\
\text { Never }\end{array}$ & $\begin{array}{l}1 \\
\text { Once }\end{array}$ & $\begin{array}{l}2 \\
2-3 \text { times }\end{array}$ & $\begin{array}{l}3 \\
4-5 \text { times }\end{array}$ & $\begin{array}{l}4 \\
6-10 \text { times }\end{array}$ & $\begin{array}{l}5 \\
\text { More than } 10 \text { times }\end{array}$ \\
\hline Age 6 to 12 & $\begin{array}{l}0 \\
\text { Never }\end{array}$ & $\begin{array}{l}1 \\
\text { Once }\end{array}$ & $\begin{array}{l}2 \\
2-3 \text { times }\end{array}$ & $\begin{array}{l}3 \\
4-5 \text { times }\end{array}$ & $\begin{array}{l}4 \\
6-10 \text { times }\end{array}$ & $\begin{array}{l}5 \\
\text { More than } 10 \text { times }\end{array}$ \\
\hline Age 13 to 18 & $\begin{array}{l}0 \\
\text { Never }\end{array}$ & $\begin{array}{l}1 \\
\text { Once }\end{array}$ & $\begin{array}{l}2 \\
2-3 \text { times }\end{array}$ & $\begin{array}{l}3 \\
4-5 \text { times }\end{array}$ & $\begin{array}{l}4 \\
6-10 \text { times }\end{array}$ & $\begin{array}{l}5 \\
\text { More than } 10 \text { times }\end{array}$ \\
\hline
\end{tabular}

3. Did you ever suffer a serious personal injury or illness?

\begin{tabular}{l|l|l|l|l|l|l}
\hline Age $\mathbf{0}$ to 5 & 0 & 1 & 2 & 3 & 4 & 5 \\
& Never & Once & $2-3$ times & $4-5$ times & 6 -10 times & More than 10 times \\
\hline Age $\mathbf{6}$ to 12 & 0 & 1 & 2 & 3 & 4 & 5 \\
& Never & Once & $2-3$ times & $4-5$ times & $6-10$ times & More than 10 times \\
\hline Age 13 to 18 & 0 & 1 & 2 & 3 & 4 & 5 \\
& Never & Once & $2-3$ times & $4-5$ times & $6-10$ times & More than 10 times \\
\hline
\end{tabular}

\begin{tabular}{l|l|l|l|l|l|l}
\hline 4. Did you ever experience the death or serious illness of a parent or a primary caretaker? \\
\hline Age $\mathbf{0}$ to $\mathbf{5}$ & 0 & 1 & 2 & 3 & 4 & 5 \\
& Never & Once & $2-3$ times & $4-5$ times & $6-10$ times & More than 10 times \\
\hline Age $\mathbf{6}$ to 12 & 0 & 1 & 2 & 3 & 4 & 5 \\
& Never & Once & $2-3$ times & $4-5$ times & $6-10$ times & More than 10 times \\
\hline Age 13 to 18 & 0 & 1 & 2 & 3 & 4 & 5 \\
& Never & Once & $2-3$ times & $4-5$ times & $6-10$ times & More than 10 times \\
\hline
\end{tabular}

5.Did you experience the divorce or separation of your parents?

\begin{tabular}{l|l|l|l|l|l|l}
\hline Age $\mathbf{0}$ to $\mathbf{5}$ & 0 & 1 & 2 & 3 & 4 & 5 \\
& Never & Once & $2-3$ times & $4-5$ times & $6-10$ times & More than 10 times \\
\hline Age $\mathbf{6}$ to 12 & 0 & 1 & 2 & 3 & 4 & 5 \\
& Never & Once & $2-3$ times & $4-5$ times & $6-10$ times & More than 10 times \\
\hline Age 13 to 18 & 0 & 1 & 2 & 3 & 4 & 5 \\
& Never & Once & $2-3$ times & $4-5$ times & $6-10$ times & More than 10 times \\
\hline
\end{tabular}

6.Did you experience the death or serious injury of a sibling?

\begin{tabular}{l|l|l|l|l|l|l}
\hline Age $\mathbf{0}$ to 5 & 0 & 1 & 2 & 3 & 4 & 5 \\
& Never & Once & $2-3$ times & $4-5$ times & 6 -10 times & More than 10 times \\
\hline Age $\mathbf{6}$ to 12 & 0 & 1 & 2 & 3 & 4 & 5 \\
& Never & Once & $2-3$ times & $4-5$ times & $6-10$ times & More than 10 times \\
\hline Age 13 to 18 & 0 & 1 & 2 & 3 & 4 & 5 \\
& Never & Once & $2-3$ times & $4-5$ times & $6-10$ times & More than 10 times \\
\hline
\end{tabular}

7.Did you ever experience the death or serious injury of a friend?

\begin{tabular}{l|l|l|l|l|l|l}
\hline Age $\mathbf{0}$ to $\mathbf{5}$ & 0 & 1 & 2 & 3 & 4 & 5 \\
& Never & Once & $2-3$ times & $4-5$ times & $6-10$ times & More than 10 times \\
\hline Age $\mathbf{6}$ to 12 & 0 & 1 & 2 & 3 & 4 & 5 \\
& Never & Once & $2-3$ times & $4-5$ times & $6-10$ times & More than 10 times \\
\hline Age 13 to 18 & 0 & 1 & 2 & 3 & 4 & 5 \\
& Never & Once & $2-3$ times & $4-5$ times & $6-10$ times & More than 10 times
\end{tabular}


8.Did you ever witness violence towards others, including family members?

\begin{tabular}{l|l|l|l|l|l|l}
\hline Age 0 to 5 & 0 & 1 & 2 & 3 & 4 & 5 \\
& Never & Once & $2-3$ times & $4-5$ times & $6-10$ times & More than 10 times \\
\hline Age 6 to 12 & 0 & 1 & 2 & 3 & 4 & 5 \\
& Never & Once & $2-3$ times & $4-5$ times & $6-10$ times & More than 10 times \\
\hline Age 13 to 18 & 0 & 1 & 2 & 3 & 4 & 5 \\
& Never & Once & $2-3$ times & $4-5$ times & $6-10$ times & More than 10 times \\
\hline
\end{tabular}

9.Did anyone in your family ever suffer from mental or psychiatric illness or have a "breakdown"?

\begin{tabular}{l|l|l|l|l|l|l}
\hline Age 0 to 5 & 0 & 1 & 2 & 3 & 4 & 5 \\
& Never & Once & $2-3$ times & $4-5$ times & $6-10$ times & More than 10 times \\
\hline Age $\mathbf{6}$ to 12 & 0 & 1 & 2 & 3 & 4 & 5 \\
& Never & Once & $2-3$ times & $4-5$ times & $6-10$ times & More than 10 times \\
\hline Age 13 to 18 & 0 & 1 & 2 & 3 & 4 & 5 \\
& Never & Once & $2-3$ times & $4-5$ times & $6-10$ times & More than 10 times \\
\hline
\end{tabular}

10. Did your parents or primary caretaker have a problem with alcoholism or drug abuse?

\begin{tabular}{l|l|l|l|l|l|l}
\hline Age $\mathbf{0}$ to $\mathbf{5}$ & 0 & 1 & 2 & 3 & 4 & 5 \\
& Never & Once & $2-3$ times & $4-5$ times & $6-10$ times & More than 10 times \\
\hline Age $\mathbf{6}$ to 12 & 0 & 1 & 2 & 3 & 4 & 5 \\
& Never & Once & $2-3$ times & $4-5$ times & $6-10$ times & More than 10 times \\
\hline Age 13 to 18 & 0 & 1 & 2 & 3 & 4 & 5 \\
& Never & Once & $2-3$ times & $4-5$ times & $6-10$ times & More than 10 times \\
\hline
\end{tabular}

11. Did you ever see someone murdered?

\begin{tabular}{l|l|l|l|l|l|l}
\hline Age $\mathbf{0}$ to 5 & 0 & 1 & 2 & 3 & 4 & 5 \\
& Never & Once & $2-3$ times & $4-5$ times & $6-10$ times & More than 10 times \\
\hline Age 6 to 12 & 0 & 1 & 2 & 3 & 4 & 5 \\
& Never & Once & $2-3$ times & $4-5$ times & $6-10$ times & More than 10 times \\
\hline Age 13 to 18 & 0 & 1 & 2 & 3 & 4 & 5 \\
& Never & Once & $2-3$ times & $4-5$ times & $6-10$ times & More than 10 times
\end{tabular}

Part 2: Physical Punishment

1. Were you ever slapped in the face with an open hand?

\begin{tabular}{l|l|l|l|l|l|l}
\hline Age $\mathbf{0}$ to 5 & 0 & 1 & 2 & 3 & 4 & 5 \\
& Never & Once & $2-3$ times & $4-5$ times & $6-10$ times & More than 10 times \\
\hline Age $\mathbf{6}$ to 12 & 0 & 1 & 2 & 3 & 4 & 5 \\
& Never & Once & $2-3$ times & $4-5$ times & $6-10$ times & More than 10 times \\
\hline Age 13 to 18 & 0 & 1 & 2 & 3 & 4 & 5 \\
& Never & Once & $2-3$ times & $4-5$ times & $6-10$ times & More than 10 times \\
\hline
\end{tabular}

\begin{tabular}{l|l|l|l|l|l|l}
\hline 2. Were you ever burned with hot water, a cigarette or something else? \\
\hline Age $\mathbf{0}$ to $\mathbf{5}$ & 0 & 1 & 2 & 3 & 4 & 5 \\
& Never & Once & $2-3$ times & $4-5$ times & $6-10$ times & More than 10 times \\
\hline Age $\mathbf{6}$ to 12 & 0 & 1 & 2 & 3 & 4 & 5 \\
& Never & Once & $2-3$ times & $4-5$ times & $6-10$ times & More than 10 times \\
\hline Age 13 to 18 & 0 & 1 & 2 & 3 & 4 & 5 \\
& Never & Once & $2-3$ times & $4-5$ times & $6-10$ times & More than 10 times \\
\hline
\end{tabular}

\section{Were you ever punched or kicked?}

\begin{tabular}{l|l|l|l|l|l|l}
\hline Age $\mathbf{0}$ to $\mathbf{5}$ & 0 & 1 & 2 & 3 & 4 & 5 \\
& Never & Once & $2-3$ times & $4-5$ times & $6-10$ times & More than 10 times \\
\hline Age $\mathbf{6}$ to 12 & 0 & 1 & 2 & 3 & 4 & 5 \\
& Never & Once & $2-3$ times & $4-5$ times & $6-10$ times & More than 10 times \\
\hline Age 13 to 18 & 0 & 1 & 2 & 3 & 4 & 5 \\
& Never & Once & $2-3$ times & $4-5$ times & $6-10$ times & More than 10 times \\
\hline
\end{tabular}

4. Were you ever hit with an object that was thrown at you?

Age 0 to 5

1

2

3

4

5 


\begin{tabular}{l|l|l|l|l|l|l} 
& Never & Once & $2-3$ times & $4-5$ times & $6-10$ times & More than 10 times \\
\hline Age 6 to 12 & 0 & 1 & 2 & 3 & 4 & 5 \\
& Never & Once & $2-3$ times & $4-5$ times & $6-10$ times & More than 10 times \\
\hline Age 13 to 18 & 0 & 1 & 2 & 3 & 4 & 5 \\
& Never & Once & $2-3$ times & $4-5$ times & $6-10$ times & More than 10 times \\
\hline 5.Were you ever pushed or shoved? & 0 & 1 & 2 & 3 & 4 & 5 \\
\hline Age 0 to 5 & Never & Once & $2-3$ times & $4-5$ times & $6-10$ times & More than 10 times \\
\hline Age 6 to 12 & 0 & 1 & 2 & 3 & 4 & 5 \\
& Never & Once & $2-3$ times & $4-5$ times & $6-10$ times & More than 10 times \\
\hline Age 13 to 18 & 0 & 1 & 2 & 3 & 4 & 5 \\
& Never & Once & $2-3$ times & $4-5$ times & $6-10$ times & More than 10 times
\end{tabular}

Part 3: Emotional Abuse

1. Were you often put down or ridiculed?

\begin{tabular}{l|l|l|l|l|l|l}
\hline Age $\mathbf{0}$ to 5 & 0 & 1 & 2 & 3 & 4 & 5 \\
& Never & Once & $2-3$ times & $4-5$ times & $6-10$ times & More than 10 times \\
\hline Age 6 to 12 & 0 & 1 & 2 & 3 & 4 & 5 \\
& Never & Once & $2-3$ times & $4-5$ times & $6-10$ times & More than 10 times \\
\hline Age 13 to 18 & 0 & 1 & 2 & 3 & 4 & 5 \\
& Never & Once & $2-3$ times & $4-5$ times & $6-10$ times & More than 10 times \\
\hline
\end{tabular}

2. Were you often ignored or made to feel that you didn't count?

\begin{tabular}{l|l|l|l|l|l|l}
\hline Age $\mathbf{0}$ to 5 & 0 & 1 & 2 & 3 & 4 & 5 \\
& Never & Once & $2-3$ times & $4-5$ times & $6-10$ times & More than 10 times \\
\hline Age 6 to 12 & 0 & 1 & 2 & 3 & 4 & 5 \\
& Never & Once & $2-3$ times & $4-5$ times & $6-10$ times & More than 10 times \\
\hline Age 13 to 18 & 0 & 1 & 2 & 3 & 4 & 5 \\
& Never & Once & $2-3$ times & $4-5$ times & $6-10$ times & More than 10 times \\
\hline
\end{tabular}

3. Were you often told you were no good?

\begin{tabular}{l|l|l|l|l|l|l}
\hline Age $\mathbf{0}$ to $\mathbf{5}$ & 0 & 1 & 2 & 3 & 4 & 5 \\
& Never & Once & $2-3$ times & $4-5$ times & 6 -10 times & More than 10 times \\
\hline Age 6 to 12 & 0 & 1 & 2 & 3 & 4 & 5 \\
& Never & Once & $2-3$ times & $4-5$ times & $6-10$ times & More than 10 times \\
\hline Age 13 to 18 & 0 & 1 & 2 & 3 & 4 & 5 \\
& Never & Once & $2-3$ times & $4-5$ times & $6-10$ times & More than 10 times \\
\hline
\end{tabular}

\begin{tabular}{l|l|l|l|l|l|l}
\hline 4. Most of the time were you treated in a cold, uncaring way or made to feel like you were not loved? \\
\hline Age $\mathbf{0}$ to $\mathbf{5}$ & 0 & 1 & 2 & 3 & 4 & 5 \\
& Never & Once & $2-3$ times & $4-5$ times & $6-10$ times & More than 10 times \\
\hline Age $\mathbf{6}$ to 12 & 0 & 1 & 2 & 3 & 4 & 5 \\
& Never & Once & $2-3$ times & $4-5$ times & $6-10$ times & More than 10 times \\
\hline Age 13 to 18 & 0 & 1 & 2 & 3 & 4 & 5 \\
& Never & Once & $2-3$ times & $4-5$ times & $6-10$ times & More than 10 times \\
\hline
\end{tabular}

5 . Did your parents or caretakers often fail to understand you or your needs?

\begin{tabular}{l|l|l|l|l|l|l}
\hline Age $\mathbf{0}$ to $\mathbf{5}$ & 0 & 1 & 2 & 3 & 4 & 5 \\
& Never & Once & $2-3$ times & $4-5$ times & $6-10$ times & More than 10 times \\
\hline Age $\mathbf{6}$ to 12 & 0 & 1 & 2 & 3 & 4 & 5 \\
& Never & Once & $2-3$ times & $4-5$ times & $6-10$ times & More than 10 times \\
\hline Age 13 to 18 & 0 & 1 & 2 & 3 & 4 & 5 \\
& Never & Once & $2-3$ times & $4-5$ times & $6-10$ times & More than 10 times
\end{tabular}


Part 4: Sexual Events

1. Were you ever touched in an intimate or private part of your body (e.g. breast, thighs, genitals) in a way that surprised you or made you feel uncomfortable?

\begin{tabular}{l|l|l|l|l|l|l}
\hline Age $\mathbf{0}$ to $\mathbf{5}$ & 0 & 1 & 2 & 3 & 4 & 5 \\
& Never & Once & $2-3$ times & $4-5$ times & $6-10$ times & More than 10 times \\
\hline Age $\mathbf{6}$ to 12 & 0 & 1 & 2 & 3 & 4 & 5 \\
& Never & Once & $2-3$ times & $4-5$ times & $6-10$ times & More than 10 times \\
\hline Age 13 to 18 & 0 & 1 & 2 & 3 & 4 & 5 \\
& Never & Once & $2-3$ times & $4-5$ times & $6-10$ times & More than 10 times \\
\hline
\end{tabular}

2. Did you ever experience someone rubbing their genitals against you?

\begin{tabular}{l|l|l|l|l|l|l}
\hline Age $\mathbf{0}$ to 5 & 0 & 1 & 2 & 3 & 4 & 5 \\
& Never & Once & $2-3$ times & $4-5$ times & $6-10$ times & More than 10 times \\
\hline Age $\mathbf{6}$ to 12 & 0 & 1 & 2 & 3 & 4 & 5 \\
& Never & Once & $2-3$ times & $4-5$ times & $6-10$ times & More than 10 times \\
\hline Age 13 to 18 & 0 & 1 & 2 & 3 & 4 & 5 \\
& Never & Once & $2-3$ times & $4-5$ times & $6-10$ times & More than 10 times \\
\hline
\end{tabular}

3. Were you ever forced or coerced to touch another person in an intimate or private part of their body?

\begin{tabular}{|c|c|c|c|c|c|c|}
\hline Age 0 to 5 & $\begin{array}{l}0 \\
\text { Never }\end{array}$ & $\begin{array}{l}1 \\
\text { Once }\end{array}$ & $\begin{array}{l}2 \\
2-3 \text { times }\end{array}$ & $\begin{array}{l}3 \\
4-5 \text { times }\end{array}$ & $\begin{array}{l}4 \\
6-10 \text { times }\end{array}$ & $\begin{array}{l}5 \\
\text { More than } 10 \text { times }\end{array}$ \\
\hline Age 6 to 12 & $\begin{array}{l}0 \\
\text { Never }\end{array}$ & $\begin{array}{l}1 \\
\text { Once }\end{array}$ & $\begin{array}{l}2 \\
2-3 \text { times }\end{array}$ & $\begin{array}{l}3 \\
4-5 \text { times }\end{array}$ & $\begin{array}{l}4 \\
6-10 \text { times }\end{array}$ & $\begin{array}{l}5 \\
\text { More than } 10 \text { times }\end{array}$ \\
\hline Age 13 to 18 & $\begin{array}{l}0 \\
\text { Never }\end{array}$ & $\begin{array}{l}1 \\
\text { Once }\end{array}$ & $\begin{array}{l}2 \\
2-3 \text { times }\end{array}$ & $\begin{array}{l}3 \\
4-5 \text { times }\end{array}$ & $\begin{array}{l}4 \\
6-10 \text { times }\end{array}$ & $\begin{array}{l}5 \\
\text { More than } 10 \text { times }\end{array}$ \\
\hline \multicolumn{7}{|c|}{ 4. Did anyone ever have genital sex with you against your will? } \\
\hline Age 0 to 5 & $\begin{array}{l}0 \\
\text { Never }\end{array}$ & $\begin{array}{l}1 \\
\text { Once }\end{array}$ & $\begin{array}{l}2 \\
2-3 \text { times }\end{array}$ & $\begin{array}{l}3 \\
4-5 \text { times }\end{array}$ & $\begin{array}{l}4 \\
6-10 \text { times }\end{array}$ & $\begin{array}{l}5 \\
\text { More than } 10 \text { times }\end{array}$ \\
\hline Age 6 to 12 & $\begin{array}{l}0 \\
\text { Never }\end{array}$ & $\begin{array}{l}1 \\
\text { Once }\end{array}$ & $\begin{array}{l}2 \\
2-3 \text { times }\end{array}$ & $\begin{array}{l}3 \\
4-5 \text { times }\end{array}$ & $\begin{array}{l}4 \\
6-10 \text { times }\end{array}$ & $\begin{array}{l}5 \\
\text { More than } 10 \text { times }\end{array}$ \\
\hline Age 13 to 18 & $\begin{array}{l}0 \\
\text { Never }\end{array}$ & $\begin{array}{l}1 \\
\text { Once }\end{array}$ & $\begin{array}{l}2 \\
2-3 \text { times }\end{array}$ & $\begin{array}{l}3 \\
4-5 \text { times }\end{array}$ & $\begin{array}{l}4 \\
6-10 \text { times }\end{array}$ & $\begin{array}{l}5 \\
\text { More than } 10 \text { times }\end{array}$ \\
\hline
\end{tabular}

5 . Were you ever forced or coerced to perform oral sex on someone against your will?

\begin{tabular}{l|l|l|l|l|l|l}
\hline Age $\mathbf{0}$ to $\mathbf{5}$ & 0 & 1 & 2 & 3 & 4 & 5 \\
& Never & Once & $2-3$ times & $4-5$ times & $6-10$ times & More than 10 times \\
\hline Age $\mathbf{6}$ to 12 & 0 & 1 & 2 & 3 & 4 & 5 \\
& Never & Once & $2-3$ times & $4-5$ times & $6-10$ times & More than 10 times \\
\hline Age 13 to 18 & 0 & 1 & 2 & 3 & 4 & 5 \\
& Never & Once & $2-3$ times & $4-5$ times & $6-10$ times & More than 10 times \\
\hline
\end{tabular}

6 . Were you ever forced or coerced to kiss someone in a sexual rather than an affectionate way?

\begin{tabular}{l|l|l|l|l|l|l}
\hline Age $\mathbf{0}$ to 5 & 0 & 1 & 2 & 3 & 4 & 5 \\
& Never & Once & $2-3$ times & $4-5$ times & $6-10$ times & More than 10 times \\
\hline Age $\mathbf{6}$ to 12 & 0 & 1 & 2 & 3 & 4 & 5 \\
& Never & Once & $2-3$ times & $4-5$ times & $6-10$ times & More than 10 times \\
\hline Age 13 to 18 & 0 & 1 & 2 & 3 & 4 & 5 \\
& Never & Once & $2-3$ times & $4-5$ times & $6-10$ times & More than 10 times
\end{tabular}

